Portland State University

PDXScholar

$5-24-1973$

\title{
The Diplomatic Stalemate of Japan and the United States: 1941
}

David Hoien Overby

Portland State University

Follow this and additional works at: https://pdxscholar.library.pdx.edu/open_access_etds

Part of the Asian History Commons, Diplomatic History Commons, Political History Commons, and the United States History Commons

Let us know how access to this document benefits you.

\section{Recommended Citation}

Overby, David Hoien, "The Diplomatic Stalemate of Japan and the United States: 1941" (1973).

Dissertations and Theses. Paper 1746.

https://doi.org/10.15760/etd.1746

This Thesis is brought to you for free and open access. It has been accepted for inclusion in Dissertations and Theses by an authorized administrator of PDXScholar. Please contact us if we can make this document more accessible: pdxscholar@pdx.edu. 
AN ABSTRACT OF THE THESIS OF David Hoien Overby for the Master of Science in Teaching History presented May 24, 1973.

Title: The Diplomatic Stalemate of Japan and the United States: 1941. APPROVED BY MEMBERS OF THE THESIS CMMMTTTFF.

\footnotetext{
Bernard V. Burke. Chairman
}

George C. Hoffmann

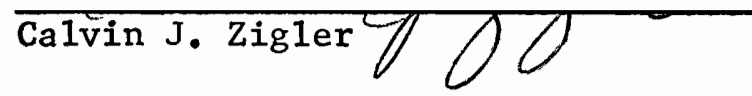

This thesis contends from the time of September 1940 to the Japanese attack on Pearl Harbor, the United States and Japan offered each no workable concessions that might have deterred war. A stalemate was firmly established between the two countries. The position of the Japanese nation was to expand and control "Greater East-Asia," while the position the United States held was one that claimed all nations should uphold certain basic principles of democracy, that all nations should honor the sanctity of treaties, and that they should treat neighboring countries in a friendly fashion.

This thesis also contends that Yosuke Matsuoka used his position as Foreign Minister of Japan to determine policy for the entire nation. 
Matsuoka led Japan in such a way that a settlement of differences between the United States and his country was not attainable through diplomatic talks. Even after Matsuoka had been removed from his position, the Supreme Command was determined to prepare for war and at the same time carry on diplomatic discussions with the United States. The only possible way that war could have been avoided was if one of the two nations had been willing to break the stalemate by giving in to the demands of the other. Neither was willing to compromise. 
THE DIPLOMATIC STALEMATE OF JAPAN AND THE

UNITED STATES: 1941

by

DAVID HOIEN OVERBY

A thesis submitted in partial fulfillment of the requirements for the degree of

MASTER OF SCIENCE IN TEACHING

in

HISTORY

Portland State University

1973 
TO THE OFFICE OF GRADUATE STUDIES:

The members of the Committee approve the thesis of David Hoien Overby presented May 24, 1973.

\author{
Bernard V. Burke, Chairman \\ Georǵe C. Hoffmánæ/// \\ Calvin J.Ziglet
}

A Dodnren.

Jesse L_Gilmóre. Head. Department of History

Bavìd T. Clark, Dean, Graduate Studies 
TABLE OF CONTENTS

CHAPTER

PAGE

I A DRAW IN THE OFFING . . . . . . . . . . •

II YOSUKE MATSUOKA . . . . . . . . . . . .

III HULL-NOMURA TALKS . . . . . . . . . .

IV KONOYE'S CHANCE . . . . . . . . . . . .

V THE QUESTION AND ANSWER • • • • • • • • • • 


\section{CHAPTER I}

\section{A DRAW IN THE OFFING}

In looking back at the years prior to the Pear1 Harbor attack, one sees several aggressive moves by the Japanese. One can also see the handicaps (successful diplomacy) encountered. In the last few months before Pearl Harbor several Japanese cabinets and cabinet members, were faced with "expansionist-pressures", to change the "status quo" in the Far East and eventually the world. Upon the conclusion of a successful war against China in 1895, Japan annexed Formosa, which at that time was interpreted by viewers as nothing more than a foothold for further strides inward. Following the Russo-Japanese War, Japan in 1905 effected a foothold in Manchuria through acquisition of a lease of the Kwantung territory and ownership of the South Manchurian Railway. At this same time they were able to acquire the southern portion of Sakhalin. In 1904 Japan guaranteed Korea's independence. In 1910 she annexed Korea. During World War I in an opportune moment, Japan presented China with "Twenty-one Demands" that encroached much on China's sovereignty that there was American fear of the "Open Door" being shut by Japan.1

In 1918 Japan became a part of a non-binding inter-a11y plan whereby severa 1 countries would send troops not exceeding 7000 members from any one country to guard the military stores in Siberia which eventually would be needed by the Russians to aid in their self-defense 
against the Bolsheviks, and also to aid in evacuating Czechoslovakian forces. Japan took this opportunity to envision annexing eastern Siberia. She sent 72,000 soldiers to Siberia which made up a military force that had more than aid for the Soviet Union and Czechoslovakia in mind. The United States sent 9000 men and the British and the French sent a few somewhat more in the bounds of the plan.2

Japan took part in the Washington Conferences of 1921-22 and eventually signed the agreements that came from them. One of these agreements was the Nine Power Treaty which was designed to provide for China full opportunity to develop and maintain a stable government. Japan pledged herself to the policies of self-restraint entailed in this treaty. She also agreed to respect the sovereignty, independence and territorial and administrative integrity of China. She also agreed to use her influence to establish the principle of equal opportunity in that country. General Tanaka's Cabinet in 1927 adopted such a policy towards China, and with success attempted to "influence" Chinese internal affairs. 3

In 1931 Japan invaded Manchuria where the government of Manchukuo was established. This was a violation of the agreements made in the Washington Conferences of 1921-22 and her adherance to the Ke1loggBriand Pact. Following the attack a Japanese delegate to the League of Nations proclaimed on November 21, 1931: "We want no more territory."4 Following the Lytton Committee Report on its investigation of the Manchurian situation Japan walked out of the League. By the end of 1936, Japan made formal announcement of their withdrawal from the Naval Limitations' agreement signed in the Washington Conferences. 5 
The Japanese people came to believe that the area of their control should be all of East Asia and the Western Pacific. The people of Asia needed Japan to give them "peace, justice and partnership for a11. . . The bayonets were merely to expel the devil who would not understand their 'true intentions."'6

The "Holy War" with China began in 1937. The results of the Boxer rebellion had given all countries involved the right of stationing troops in the Chinese capital of Peking, and also the right to station them along the railway which provided communication with the sea. This was done to prevent another such rebellion from happening. There had also been an agreement made stating that foreign troops had the right to engage in field exercises and rifle practice, "without informing the Chinese authorities."7 After thirty years of this protection from rebellion, the French had somewhere between 1700 and 2000 troops, the British had just a few more than a 1000, and the Japanese were supporting a force of at least 7000 soldiers and possibly as many as 15,000, ". - a number far in excess of that needed for the purposes envisaged in the Boxer Protocol." 8

In June of 1937, these Japanese troops were engaged in nighttime maneuvers in the area of the Marco Polo Bridge close to the city limits of Peking. It had appeared to the Chinese that the Japanese were • attempting to secure a better position for her troops in Peking. Since 1931 it should be remembered that the Chinese were quite experienced with the encroaching tactics of the Japanese in their country. The Chinese had taken some precautions in this area to make sure the Japanese were not doing anything that would give them claim to more 
territory. They had requested from the Japanese that any nighttime maneuvering by her troops should be announced ahead of time so that any of the Chinese people in the area could be warned and kept safe.

On the night of July 7 , the Japanese conducted nighttime maneuvers without giving any notice. General Chin Teh-chun, Commander of the Chinese Military in the Hopei-Chahar area, was informed by the Commissioner of Foreign Affairs of the Hopei-Chahar Council that Colonel Matsui, Commander of the Japanese Army in this area, had complained that a company of Japanese soldiers on night maneuvers near Lukouchiao had been fired upon, that one Japanese soldier was missing, and that they wanted to enter Wanping in search of him. The General refused to sanction Japanese entry into the town. He told the local Chinese commander to hold Wanping against any Japanese attack. The general took the view that these nighttime maneuvers were illegal and that the Chinese could not be held responsible for the missing soldier. He in turn offered the Japanese a search, utilizing the Chinese forces, in Wanping for the missing soldier. A joint investigation was agreed upon during the course of the night, but in the meantime, the Japanese brought their troops within range of the city of Wanping and opened fire. 9 The following day on July 8, the Chinese were told that if they did not surrender they would be attacked. The Chinese refused to bow to surrender and fighting followed. The Japanese suffered numerous casua1ties. 10 On the next day July 9, the Chinese were informed that the missing soldier had been found and they suggested terms for an immediate truce which the Chinese accepted. 11 
The "incident" would have ended had the Japanese on their withdrawa1 not left a detachment of approximately one hundred men behind. This hard-to-explain event probably can be blamed for the continuing of the "incident." At midnight on July 9, these soldiers began firing on the town of Wanping. Japanese troops began pouring into this area. Within three days the total number of Japanese troops leveled off at 20,000 men with air cover provided by 100 planes. 12 The Kwantung army (the Continenta1 Japanese Army) had moved in several units into the Wanping area. The danger of an increase in hostilities had been created by this action and movement of Japanese troops.

The cabinet in Tokyo on hearing of this "China Incident" decided that it should be limited immediately so as to obtain a speedy local settlement. This was on July 8. The Japanese army's actions made this settlement-business very difficult. One authority compares a "local settlement" to that of Texas settling a boundary dispute with Mexico without notifying the federal government of the United States. 13 By July 20, following the Army's recommendations, the Konoye Cabinet authorized the mobilization of three divisions of the Japanese forces. One week later the commander of Kwantung's forces informed Tokyo that he had attempted every way possible to settle the differences through negotiations and he was now recommending force. This recommendation was approved by the military authorities in Tokyo without any recorded objection or questioning by the cabinet. 14 The basic rationale in Tokyo for sending more troops to China was to guarantee the safety of Japanese nationals and Japanese property. 15

Fighting continued off and on. Nanking offered to negotiate. The United States "tendered its good offices." Japan would not have 
anything to do with a middle nation.

What in fact was Japan doing? Some people in Japan saw their country as the "Messiah" for the Asian countries. They saw their Asian counterparts divided between the Colonial Empires of Great Britain, the Netherlands, France, Portugal, and the United States. They overlooked the fact that these colonial powers ruled over a divergent population and maintained peace and order.

Part of Japan's expansionism came about because of jealousy. There was a conflict over prestige and power between the armies stationed on the Asian mainlands and that of the armies in Japan. During the period of two years in 1931-33, the Kwantung (the Continental Japanese Army) had taken Manchuria and Jehol from the Chinese and had organized the puppet-state Manchukuo. A direct result from the formation of the puppet-state Manchukuo was an increase in favorable Japanese public opinion toward the Army. 16

As a result of the newly acquired possession, two schools of thought appeared in Japan. One was to get the most possible out of Manchuria and that was all. The other was to get the most possible out of Manchuria and go a step further into China and create a buffer zone. It was even suggested that this was an extremely good opportunity to go into Inner Mongolia and undermine Soviet influence in Outer Mongolia. The object of this move would be to establish a corridor between China and the U.S.S.R. that Japan controlled.17

The Cabinet in sensing the different views of what should be done on August 11, 1936 attempted to write a policy that appears to be a compromise between Japan's military leaders of Japan and the foreign 
policy-makers. This compromise, called "Basic Principles of National

Policy" stated:

1.) Japan must strive to correct the aggressive policies of the greater powers and to realize the spirit of the Imperial Way by a consistent policy of overseas expansion.

2.) Japan must complete her defensive armament to secure the position of her empire as the stabilizing power in East Asia.

3.) Japan should strive to eradicate the menace of the U.S.S.R. in the north in order to stabilize Japan's Manchukuo national defense and to promote sound economic development. Japan should also be prepared against Britain and the United States, and attempt to bring about economic development by close collaboration between Japan, Manchukuo and China. However, in achieving these objects Japan should pay due attention to friendly relations with other powers.

4.) To further her plan to promote social and economic development in the South Seas, and without rousing other powers, Japan should attempt to extend her strength by moderate and peaceful means. Thus with the establishment of Manchukuo Japan might expect full development of her national resources and her national defense. 18

The Kwantung Army was more. aggressive-minded than this policy

allowed for. In fact, they were not at all receptive to the moderate peaceful policy Tokyo was attempting to indoctrinate them with. This nonacceptance of policy was based on the Kwantung's belief that a united front was being formed against Japan in China by the forces of the Koumintang-Communists. Hideki Tojo sent a telegram to the Genera1 Staff of the Japanese Army in June warning them of this possibility and he suggested that Japan should be the first to strike against Nanking. 19 The War Minister and the Chief of the General Staff in Tokyo did not agree with Tojo's advice. There were evidently many in the lower echelons of the Army both home and abroad who thought as he did. The danger, of course, was that the Army was not willing to give up its idea of a buffer zone between Manchuria and China. The Army of the mainland was not interested in the new "Basic Principles of National Policy." 
The Kwantung Army, faced with the choices of withdrawal of its troops and reliance on peaceful problem-solving methods or expansion of the buffer zone, that was to keep the Japanese-claimed territories in Manchuria safe from the Koumintang-Communists, by use of military force, chose to ignore the policy of peace and to use the Marco Polo Bridge "incident" to expand Japan's buffer zone. It should be emphasized that the Marco Polo Bridge "incident" was not a Japanese premeditated 1ongrange plan, but rather a spontaneous outburst of violence between small numbers of Chinese and Japanese soldiers. The Kwantung's decision to enlarge the zone through force, chose to take a narrow militaristic look at the "incident" which reveals the army's inability to face the facts of the outcome of such expansionist goals.

This inability to size up the situation realistically is shown by Hideki Tojo in his estimation of the "China Incident" as being nothing more than a "family quarre1." In the post-war interrogations he stated:

There was real fighting to be sure, but it was considered to be a family quarrel, in which the younger brother, China, was being made to reconsider its various illegal acts typified by such anti-Japanese phrases as konichi (oppose the Japs) and hainichi (expel the Japs). The basic purpose was always the fostering of good neighborliness and friendship and for that reason the thing was never called a war nor was there a declaration of war. 20

Not only the Kwantung's leaders but one of Japan's future Foreign Ministers, Yosuke Mastuoka, told the Associated Press about the "brotherly quarre1," a few months after the "incident."

China and Japan are two brothers who have inherited a great mansion called Eastern Asia. Adversity sent them both down to the depth of poverty. The ne'er-do we11 elder brother turned a dope fiend and a rogue, but the younger, lean, but rugged and ambitious, ever dreamed of bringing back past glories to the old House. He sold 
newspapers at a street corner and worked hard to support the house. The elder flim-flammed the younger out of his meager savings and sold him out to their common enemy. The younger in a towering rage beat up the elder--trying to beat into him some sense of shame and awaken some pride in the noble traditions of the great house. After many scraps, the younger finally made up his mind to stage a show-down fight. And that is the fight now raging along the North China and Shanghai fronts. 21

Matsuoka's analogy of the conflict, to say the least, is overstated in that he takes the spontaneous action at the Marco Polo Bridge and makes it into a "show-down fight." The "show-down" fight emerged after the "incident" not as a premeditated move on the part of the Japanese military in China.

The action taken in China by the Japanese was reported to the American public. One who would read the papers of America during the months following the "China Incident" would find that, in most cases, the news bulletins, the reporting, and the editorials portrayed a negative view of the Japanese. The fact that the papers were reporting this view does not necessarily mean that the reader was accepting it. But again in most cases, other than magazines, radio, and "word of mouth," the newspapers' opinions and views were all the public would learn about the intent of the Japanese in China.

From pursuing through the back files of the Oregonian, the Oregon Journa1, and the New York Times, it is noted when the "China Incident" continued on into more acts of conflict instead of ending in peaceful negotiations, the reporters, the political cartoonists, and the editors a11 put the blame on a "greedy-expansionist-nation" called Japan. The public was told that the Japanese were not to be trusted, that "mass 
murder" was in the offing, that the Japanese were being led by a "bloodthirsty, power-hungry, expansionist" group of military leaders. 22

Some examples of this type of reporting and editorializing follow. The New York Times on July 11, headlined: "PEACE MOVE FAILS, JAPAN IS SUSPECTED OF PLAN TO INCREASE HOLD ON NORTH CHINA," and "JAPAN SEES A BIG CHANCE." The comments in this article ranged from ". . another Mukden promise," to "Japan is on the march to her manifest destiny." 23

Four days later the Oregonian presented this editorial which helps illustrate the prevalent attitude portrayed in the papers of distrust and suspicion of Japan.

On all fronts Japan is particularly aggressive these days. It is uncompromising in its defense of the Japanese fishermen who frequent Bristol Bay, Alaska; it bombards Russians who have "invaded" a sandbar or two in the Amur River on the Manchurian border; probably its troops are fighting on the Mongolian frontier--they usually are; and now there is outright war, though undeclared war around Peiping. . . Ever since the Manchurian invasion in 1931, the Japanese army has either controlled the cabinet directly or overawed it. In any case, the Army is not responsible to the Cabinet. It is responsible only to the Emperor. If the Army wants to start a war in Asia, it does so and lets the civilian government do the worrying about explaining the affair to the world and about the funds needed. It seems determined to bring about foreign complications which will frighten the Japanese voters into granting everything the army desires in the way of appropriations and war preparations. 24

An edition of the New York Times later in the month asked through a headline this question. "NINE POWER TREATY NOT WORKING--WHAT DOES JAPAN SEEK?" In reply to the question the paper responded:

Incidents there are always. Sometimes Japan has used them to take over further advantages in North China; sometimes they have been forgotten. It all depends on what use is made of the incident . . . the big question is whether Tokyo intends to use the situation to take formal control of Peiping and 
Tientsin thus cementing her hold on Hopei Province and on North China . - on the other hand bluff always plays a part in Oriental diplomacy. 25

The views of these papers hardly suggested any form of discipline toward Japan. More or less, the papers pointed out that what Japan was doing in China was unfair.

The realization that public opinion would be against action of any kind on the part of the United States was made evident by Cordell Hull when, due to a confrontation on the part of France and Great Britain wanting the United States to enter into a joint-action to stop the Japanese-Chinese crisis, he reacted in fear of what the public would do. The influence of public opinion upon his reasoning was obvious when he stated,"... that anything resembling joint action with Britain inevitably aroused the fears and animosity of the isolationist elements in the United States. 25

President Roosevelt in one of his more famous speeches, which incidenta11y was prepared by the State Department, inserted his selfinitiated and self-worded "quarantine clause." The prepared portion by the State Department had been worded much more careful1y. 26 The clause inserted by the President that upset many was thus worded.

The peace, the freedom, and the security of 90 percent of the population of the world is being jeopardized by the remaining 10 percent, who are threatening a break down of international order and 1aw. Surely the 90 percent who want to live in peace under law and in accordance with moral standards that have received almost universal acceptance through the centuries, can and must find a way to make their will prevail. - . It seems to be unfortunately true that the epidemic of world lawlessness is spreading. When an epidemic of physical disease starts to spread, the community approves and joins in a quarantine of the patient in order to protect the health of the community against the spread of the disease. 27 
In the United States the suggestion of sanctions caused an uproar of adverse comments within the legislative branches of the government. Roosevelt who was the "extreme suave politician," promptly drew back and tried to explain his unfortunate language. Obviously this pointed out to the politicians and statesmen that any kind of activities that would cuase the United States to be a part of a conflict in the world would be accepted with great amounts of ill feeling on the part of public opinion. 28

Secretary of State Hull was extremely upset by the "clause" and wrote in his diary:

The reaction against the quarantine idea was quick and violent. As I saw it, this had the effect of setting back for at least six months our constant educational campaign intended to create and strengthen public opinion toward international cooperation . - we were always careful not to go too far lest a serious attack by the isolationist element throw us farther back than we were before. If we proceeded gradually and did not excite undue opposition, our words and actions although not so dynamic or far reaching as we might wish had more effect on the world at large than if we made startling statements or took precipitate action and then, because of the bitter reaction we aroused, presented the world with the spectacle of a nation divided against itself. 29

The "quick and violent" reaction came in the form of a declaration issued by six organizations that could be categorized as pacifist. The declaration stated that the President "points the American people down the road that led to the World War." The American Federation of Labor issued the resolution that "American labor does not wish to be involved in European or Asiatic wars." Members of the House of Representatives threatened to have the President impeached. A poll of Congress taken by the Philadelphia Inquirer showed its membership was more than two to 
one against common action with the League in the Far East. A campaign was launched by the six organizations to secure some 25,000,000 signatures to a "Keep America Out of War" petition. 30

From this point in history, American public opinion can be interpreted to have said that it was not in favor of activities that would draw America into a conflict or war. Yet one might also add that with the newspapers indoctrinating the American public to believe the Japanese were untrustworthy and planning more military advancements in China, American public opinion concerning Japan worsened. Still the fear of public opinion would not allow the government of the United States to do anything of major consequence about Japan.

The war in Europe certainly was of great importance to the rest of the world. In Asia, the Japanese militarists who had spontaneously chosen to use the "incident" of 1937 in China to gain a buffer zone between Manchuria and China, had a11 the time been eager to join their hands with the Germans. What Hitler had done in the spring and summer of 1940 stirred the expansionists of Japan as nothing had before. Hitler had made tremendous strides in taking over parts of Europe. Poland had been crushed earlier between two forces in hardly more than two weeks' time. During this time much to the dismay and frustration of the militarists the fighting in China dragged on into 1940. The Army General Staff decided in secret that unless total victory was achieved within the year, Japan's forces would have to be withdrawn from China, leaving only a "skeleton crew" of troops in Northern China as a protection against the spread of communism. The expansionist-attitudes were being forced to cool by the slow turn of events in Japan. Yet, 
six weeks later on May 10, Hitler's blitzkrieg on the western front gave Japan refired hope. The Dutch surrendered, the French admitted defeat, King Leopold III surrendered, and the British hopes of being able to hold out against the Germans seemed to be doomed. Needless to say, the Japanese military leaders, intoxicated by Hitler's easy victories, changed their minds about the policy of troop removal. They adopted the slogan which in effect became the new policy, "Don't miss the bus!"31

The time for Japan to move was ripe. France had been defeated while Britain, seemingly, was barely holding on trying to avoid the pitfall of defeat. There was never a better time for Japan to strike into the Southeast Asian area for her needed supplies of both oil and natural resources.

On the morning of June 22, the Army General Staff and the War Ministry held a joint meeting. Those who had recently advocated a withdrawal from China changed their minds. The new recommendation from this group was an immediate surprise attack on Singapore. The scheme was squashed by conservatives, but at least the victorious German army had given the Japanese military a new "spirit of chance."32 Obviously the crystal ball which seemed to have predicted defeat to the militarists now took on a new glimmer of what could be done and of what could be obtained. If Hitler could gain such sudden good fortune in Europe, why not Japan in Southeast Asia?

The problem in China had been one of vast areas which made it virtually impossible to pin Chaing Kai-shek's Nationalist Army down. There had been 1ittle prospect of subduing China as long as the foreign powers--Russia, Britain, and the United States--continued to give the Chunking Government material support. 33 
Against the background of undefeatable China and "her friends," appeared an alluring vision of the riches in Indo-China. Defeated France was the possessor of the rich states of Indo-China, while the powerless Netherlands held the East Indies, from which Japan hoped to secure strategic supplies in oil and materials.

There was at this time a logical stepping stone for the Japanese to step on in establishing claims in the southeast Asian area. The French and the Dutch possessions in the Far East were virtually, due to the latest German victories, under German control. Britain was hardly in a position to block Japan's attempts at building her new "Greater East Asia Co-Prosperity Sphere" for Britain was up to her ears in war. The United States had given numerous signs to the Japanese that even if Japan would make moves toward southeast Asia, it was believed that the United States would not involve herself in any activities that would lead to conflict. The logical step for the Japanese then was to join with Germany to gain an agreement on Japan's rights to establish her new sphere in southeast Asia. 34

In the past there had been opponents to an alliance with Germany. More than seventy times during the spring and summer in 1939, the Hiranuma Cabinet found itself discussing and wrestling with the texts of a possible alliance with Germany. 35

The main issues the cabinet seemed to be wrestling with were 1) whether the pact would apply only in the event of war with the Soviet Union--or also in the event of war with others; 2) whether or not the countries of the alliance were obligated to war if any member should go to war; and 3) whether the pact was to contain a promise of 
"effective military support" or something less. Every method conceivable was used to gain a pro-Axis Cabinet. Those who sided with the Germans gave false information to the Emperor, made threats of violence against those who balked at the alliance on the Cabinet, and gave misinformation, suppressed information beneficial to the anti-Axis "moderates" or allowed classified information to leak out to the press. A11 of this was done in an attempt to "wear out" those members of the government that were against the alliance with Germany.36 The proEnglish elements seemed to be the Foreign Ministery Arita, who stood very firm against any deal that would obligate Japan to go to war against the British and the United States, the conservative financial and business circles, and the Emperor's court which looked upon any pact with the Axis as a move in the wrong direction. 37

The militarists, made up of the Army "center" and nationalist groups that saw Japan with like interests and oppositions as the Axis powers, tried to frighten the officials in that circle by stirring up popular feeling against them. That is, everyone except the Emperor, who was sacred was dishonored, yet even he was reminded of the times his predecessors were kept under lock and key.38

The inevitable happened. A new cabinet was formed. Hiranuma's successor was General Nobuyuki Abe who lasted only four and a half months because of his and his Cabinet's inability to keep the support of the army, the diet and the people. 39

Another government was formed which was not much stronger than the Abe Cabinet. The Yonai-Arita Cabinet, considered to be moderate, governed Japan from January to July 1940 until the military forced it 
to disband. The military and other circles of influence in Japan found it necessary to force the Cabinet to reopen the avenues to a military alliance with Germany. This is the basic flaw the military found in the Yonai Cabinet. The Cabinet had "systematically opposed" the German Alliance which left the Army little room for confidence in them and their abilities to move with the desires of the Army for such an Alliance. 40 On July 16, the High Command engineered the downfall of the Yonai Cabinet and arranged for a new government under Prince Fumimaro Konoye, with General Hideki Tojo as Minister of War and Yosuke Matsuoka as Minister of Foreign Affairs.

It is really very easy to see the effect the European War had upon Japan's attitudes of expansionism and the "new order" in East Asia. The attitude of the Japanese was one of opportunism. The golden opportunity afforded them by the German conquests in Europe showed her that a change in the status quo in Asia was entirely possible. This was not only due to the conquests in Europe but the effect of the conquests on the European colonial powers. The fact that several of the colonial powers of Southeast Asia were subdued or involved to the point that hardly any military support to this area of the world could be given, aided the Japanese desire to move while the time was right. Japan asked herself, "would there ever be an opportunity like this again?"

On November 3, 1938 Premier Konoye proclaimed the ". . . estab1ishment of the New Order in East Asia . . " and made inference that third rate countries would have only the alternative of adjusting to it. The Japanese were going to monopolize at this point such Chinese 
products and industries as she considered essential for her economy. This in reality was only a carryover from her "twenty-one demands." Japan did not want to be treated as a third rate power, nor a second rate power for that matter. East Asia was her backyard, yet the "old colonial powers"--Great Britain, France, the Netherlands, and the United States--claimed more economic rights in the area than Japan. Japan was stating to the world in Prince Konoye's proclamation that she believed in her destiny to be the new leader of East Asia.41

General Hideki Tojo in the post war trials explained how he interpreted Japan's "new order." He saw this as "a matter of fundamenta1 importance." He explained that there had been "from very early times" a need for close ties between Japan and China. The "Manchurian Incident" was the earliest effort to bring about adhesion between the two. General Tojo pointed out that Japan was influenced, due to her geographical position, by internal conditions in China much more than any of the other powers interested. "Disorder and instability in China could spread quickly to Japan. By contrast, England and America were more remote from China and were not seriously affected by chaotic conditions there. . the problem was much less serious."42 Butow paraphrases Tojo's interpretation of the "new order" and why it was necessary .

As the "central power" in East Asia, Japan wished "to insure the stability of the Far East." This did not mean that other nations would either be under Japan or become her dependencies, but only that Japan, "by reason of her greater strength, would have the initiative." Japan did not intend to "push aside" the Far Eastern interests of the European powers and of the United States. The sole purpose was to "effect lawful adjustments." .. According to Tojo, an en1ightened approach had characterized Japan's thinking about the new order from the very beginning. He 
insisted that such a selfish thought as greater wealth for Japan had not existed. "The basic intention was that the raw materials which China possessed in abundance would be contributed by China and the technique, capital and skilled personnel would be contributed by Japan for the mutual benefit of both countries. Manchuria would come into the picture similarly. . . The idea of profit or loss did not enter in. The idea of mutual benefit was the main one. It had a moral basis. 143

Konoye had told correspondents in 1938, shortly after the declaration of a "new order" that

". . it is imperative... the economic activities of other Powers should be subject to certain restrictions dictated by the requirements of the national defense and economic security of the countries grouped under the new order. - . But, even if these restrictions are put in force, there will remain vast field of commercial and economic activity open to the people of other Powers. 44

Great Britain, France, and the United States voiced their disagreements and opposition to the Japanese "shake-up." While in Japan this opposition was denounced in terms showing the opponents of the "new" Japan as members of an elite club of nations who were repeatedly refusing Japan her "correct-position" in the world. 45

The Konoye cabinet had only been in power just a few days when it endorsed unanimous1y a "new national policy." Basically the policy was aiming its main thrust toward world peace. World peace, it was stated, could only be brought about by forming a "new order in Greater East Asia" uniting Japan with Manchukuo and China, under of course, Japan's leadership. Also it was determined that a tripartite pact would be signed with Germany and Italy, and a nonaggression treaty with the Soviet Union. 46

A change in the status-quo was being demanded by Japan. Japan was preparing itself on a national basis for a war economy. Alliances with 
Germany and Italy were to be made showing the United States a "firm attitude," that Japan would do what she thought right and not be a servant to the major powers. 47 Adjustments with the Soviet Union were to be made. Japan boldly declared to the world that she was the new supervisor of East Asia.

The American attitude toward Japan was deteriorating. Hardly anyone in America trusted Japan and her "new policy", nor seemed to know how much to fear the Japanese, or how to control them.

It was apparent to many in 1937 that the Japanese were launching upon a militarily aggressive conquest of the Far East. How far this conquest was to go, no one could say for sure. But it was apparent that the United States could not remain passively indifferent to a rewriting of the status quo in the Far East which would endanger its position.

This change from being passively indifferent began to take place in the late 1930's. Some examples of a change were when the United States gave her moral support to the Chinese. A Roosevelt-added phrase in his speech of October, 1937 suggested "quarantine" for lawless and aggressor nations. In July 1938, the State Department imposed its "moral" embargo upon the export of airplanes to Japan. The "Holy War" of Japan, in spite of American peaceful persuasiveness, continued to drag on seemingly with more and more sections of China falling into the hands of the Japanese. The public was becoming more vocal in wanting to stop the Japanese military efforts by placing economic sanctions on the Japanese. 48

On July 10, 1939, Secretary of State Hull met with the Japanese Ambassador Horinouchi to tell him among other things: 
Nations cannot but take notice that Japan herself is engaged in military operations for purposes of conquest. This situation well calls for an ending if Japan is to exercise her fullest influence, along with the United States and other countries, to compose threatened military conquest in other parts of the world. . . I need not remind you that for six years I have been earnestly pleading with your government and urging the view that there is enough room on this planet for fifteen or eighteen great nations like yours and mine. . . Our big consideration is whether a11 China and the Pacific islands near by are to be "Manchurianized" by Japan, with international law and treaties abolished and a11 other nations not allowed into that half of the world-the door shut and locked by Japan--except over a wall of preferences for her own citizens. . . 49

By the summer of 1939 , the administration in Washington was thinking in terms of abrogating the treaty of commerce and navigation signed with Japan in 1911. Secretary of State Hu11 and President Roosevelt discussed reasons, which Hul1 noted in "rough-thoughts," for giving notice to the Japanese that the Treaty of 1911 was ended.

Why keep up treaty when Japan does as she pleases with U.S. interests in China? U.S. for two yrs has tried hard to be friendly . - while all sorts of indignities, etc. have been suffered.

Japan is clearly attempting the subjugation of China, despite her sworn duty to protect China against such attacks as they [Japs 7 are making.

When Jap spokesmen were shouting their "new order," their domination of Western Pacific, etc. \& that British had knuckled to them, that Japs had won "a sweeping diplomatic victory," etc. etc., it was high time U.S. was reproclaiming [anew7 its attitude on Far Eastern affairs.

U.S. action has the effect of encouraging China, Britain, - \& also of discouraging Japs, Germans, \& Italians, but it all grows out of Jap violation of 9-Power treaty. . . 50

This was a "policy of resistance" on the part of the United States towards Japan which had been growing in strength. Japanese actions in China in 1938 were given somewhat of a "moral embargo" when the United States placed a ban on the exporting of airplanes and related materials used in bombing civilian targets. 51 When Japan occupied several 
strategic islands between China and Indo-China, the United States moved her fleet to the Pacific Ocean, eventually to Pearl Harbor. When the war in Europe broke out, America took an introspective inventory of her raw materials and resources that would be necessary in maintaining her security. By the summer of 1940, arguments in Washington over economic embargoes on the flow of scrap iron and oil were heard. The State Department feared taking a "too-tough" stand against Japan, whereas certain members of the cabinet urged the President to take a "very-firm" stand and stop all sales of scrap metal and oil to the Japanese. The State Department won out in the end and an embargo of such magnitude was not placed on the Japanese. 52

A milder form of an embargo on July 2, 1940 was authorized by the United States Congress. The Congress gave Roosevelt permission to prohibit or curtail under license the export of strategic materials to conserve war supplies in America. It was announced that starting in August aviation gasoline and most types of machine tools could no longer be exported to Japan. 53 But even so, these actions were mere gestures to a country on the move with a powerful army and navy wanting only their share of the world.

In the early fall of 1940 the new Konoye cabinet took over. The United States' ambassador to Japan, Joeseph Grew made these observations about the cabinet which had been in operation only a few days.

For at first sight the Konoye Government, interpreting popular and especially military demand, gives every indication of going hell-bent toward the Axis and the establishment of the New Order in East Asia, and of riding roughshod over the rights and interests, and the principles and policies, of the United States and Great Britain. 54 
The facts as given by means of "visions" by Ambassador Grew, soon became reality. Indications were being received that pointed to Japan's keen interests in areas adjacent to China. Walter Millis gives vivid interpretation to Japan's actions in the French territory of the Far East.

The indications were soon being fulfilled. Within the month, the tiger of Japanese militarism, already standing with dripping jaws over vast areas of China, was reaching a stealthy and letha1 paw around the Chinese flank into the French territory of Tonkin, in northern Indo-China. 55

To insure the "Japanese-right" of occupying and controliing these portions of Southeast Asia, the Konoye Cabinet, with pressure from the Supreme Command, set out to obtain an alliance, with Germany and Italy. This was accomplished over a two-month period of time. The document was signed on September 27, 1940 by Yosuke Matsuoka, the Japanese Foreign Minister, in Berlin. In short, the Pact declared in writing to the United States and the rest of the world that Japan was moving toward the German camp. In the same sense, the United States moved closer to the British camp.

Over the past years, words, gestures, sanctions, and embargoes had been exchanged between the United States and Japan. Now a Pact had been signed by Japan with the Axis powers. It was now time for the poised nations of Japan and the United States to "flex their war-muscles."

A turning point in the flexing of muscles of the United States military was heard on Sunday evening, December 29, 1940 when most of the nation 1istened to Franklin Roosevelt give an unusual "fireside chat."

This is not a fireside chat on war. It is a talk on nationa1 security. . .

Never before since Jamestown, and P1ymouth Rock has our American civilization been in such danger as now. . . 
The Axis not merely admits but proclaims that there can be no ultimate peace between their philosophy of government and our philosophy of government. - . It can be asserted, properly and categorically, that the United States has no right or reason to encourage talk of peace until the day sha11 come when there is a clear intention on the part of the aggressor nations to abandon all though of dominating or conquering the world. . .

Some of our people like to believe that wars in Europe and in Asia are of no concern to us. But it is a matter of most vital concern to us that European and Asian warmakers should not gain control of the oceans which lead to this hemisphere. •.

The British people are conducting an active war against this unholy alliance. Our own future security is greatly dependent on the outcome of that fight. Our ability to "keep out of war" is going to be affected by that outcome. . . I make the direct statement to the American people that there is far less chance of the United States getting into war if we do all we can now to support the nations defending themselves against attack by the Axis than if we acquiesce in their defeat, submit tamely to an Axis victory, and wait our turn to be an object of attack in another war later on....

There is no demand for sending an American expeditionary force outside our own borders. . . Our national policy is not directed toward war. Its sole purpose is to keep war away from our country and from our people. . . .

But all our present efforts are not enough. We must have more ships, more guns, more planes,--more of everything. . . Your Government, with its defense experts, can then determine how best to use them to defend this hemisphere... .

We must be the great arsenal of democracy. For us this is an emergency as serious as war itself. . . There will be no "bottlenecks" in our determination to aid Great Britain. . . .

I have the profound conviction that the American people are now determined to put forth a mightier effort than they have ever yet made. - . As President of the United States I call for that national effort. . . 56

The stronger, more emphatic stand was certainly necessary by

December, at least according to Ambassador Grew. In a letter to

Rooseve1t entitled "Dear Frank" Grew asserted it was time for America to

flex her muscles even more so in the area of the "embargo."

It seems to me increasingly clear that we are bound to have a showdown someday, and the principal question at issue is whether it is to our advantage to have that showdown sooner or to have it later. . . Only insuperable obstacles will now prevent the Japanese from digging in permanently in China 
and from pushing the southward advance . . under present circumstances no Japanese leader or group of leaders could reverse the expansionist program and hope to survive. . . . It therefore appears that sooner or later, unless we are prepared . . to withdraw bag and baggage from the entire sphere of "Greater East Asia including the South Seas" (which God for bid) we are bound eventually to come to a head-on clash with Japan.

- . It is important constantly to bear in mind the fact that if we take measures "short of war" with no real intention to carry those measures to their final conclusion if necessary, such lack of intention will be all too obvious to the Japanese, who will proceed undeterred, and even with greater incentive, on their way. Only if they become certain that we mean to fight if called upon to do so will our preliminary measures stand some chance of proving effective and of removing the necessity for war. . . .57

Later Mr. Grew on New Year's Day, 1941, had been so inspired by

President Rooseve1t's "Arsenal of Democracy" speech that he wrote the

following in his diary:

With a11 our desire to keep America out of war and at peace with all nations, especially with Japan, it would be the height of folly to allow ourselves to be lulled into a feeling of false security. Japan, not we, is on the warpath, and that path is not a whit the less dangerous to our own future welfare because it is camouflaged in such righteous-sounding terms as the "New Order in Greater East Asia including the South Seas" and the "Greater East Asia Co-Prosperity Sphere." If those American who counse1 appeasement could read even a few of the articles by leading Japanese in the current Japanese magazines wherein their real desires and intentions are given expression, our peaceminded fellow countrymen would realize the utter hopelessness of a policy of appeasement. The time for that has passed. . . . Unarrested, the cancer will progressively invade everything within reach until its malignant control can perhaps never be checked. But if the cancer is arrested and rendered impotent in its earlier stages, we may yet see Japan return to healthy ways, when constructive instead of destructive forces may again contro1. . . It may become open to question . . whether we should allow Japan to dig in throughout the areas where she now visualizes far-flung control. That question, I think, will depend upon the tempo of the Japanese advance. In the meantime let us keep our powder dry and be ready--for anything.

- - To those of our fellow countrymen who want to get into bed and pull the covers over their heads, it is an invincible clarification and an unanswerable warning. 58 
The President responded to the Ambassador's letter on January 21. It came across $10 u d$ and clear to Grew that the President was in close agreement with his attitudes about Japan and the methods to be used.

I have given consideration to your letter of December 14. . . As to your very natural request for an indication of my views as to certain aspects of our future attitude toward developments in the Far East, I believe that the fundamental proposition is that we must recognize that the hostilities in Europe, in Africa, and in Asia are all parts of a single world conflict. We must consequently, recognize that our interests are menaced both in Europe and in the Far East. We are engaged in the task of defending our way of life and our vital national interests wherever they are seriously endangered. Our strategy of self-defense must be a global strategy which takes account of every front and takes advantage of every opportunity to contribute to our total security. . .

President Roosevelt had also written in the letter to Grew, "Our strategy of giving assistance (to Great Britain) . . must envisage both sending of supplies to England and helping to prevent a closing of channels of communication to and from various parts of the world, so that other important sources of supply will not be denied to the British and be added to the assets of the other side." 59 This letter was in so many words telling Grew that the United States would be, if Roosevelt had his way, taking on a policy of preventing any Japanese attack upon the Dutch or British possessions in the Far East. This proposal for a Lend-lease type of situation was similar to the commitment the Japanese had with Gemany in the Tripartite Pact which was partially created to keep us out of the war with the Axis countries. The risks involved in actually doing something like this to halt the Japanese expansionism and also the cost to the United States were definitely bold suggestions made to Grew. One wonders if the President actually envisioned 
the consequences of such plans. Regardless, the muscles were beginning to move against the Tripartite Powers.

The United States was aware of the power and might of the German and Italian armies, but what of the Japanese military force? How serious was a country supposed to take the military might of Japan. She had been making a somewhat futile attempt at bringing the "Holy War" in China to a successful ending. It was believed by the opponents of the "Japanese-aggressors" that if Japan was faced with a united effort by America and Great Britain to militarily handle the Japanese, the Japanese would have neither the fortitude nor courage to stay for the battle. 60

On January 6, 1941 President Roosevelt declared in his annual message to the Congress that never had American security been so seriously threatened from without, and that never had direct assaults on the democratic way of life been made so continuously both by arms and propaganda.

Let us say to the democracies: "We Americans are vitally concerned in your defense of freedom. We are putting forth our energies, our resources and our organizing powers to give you the strength to regain and maintain a free world. We sha11 send you, in ever-creasing numbers, ships, planes, tanks, guns. This is our purpose and our pledge."

In fulfillment of this purpose we will not be intimidated by the threats of dictators that they will regard as a breach of international law or as an act of war our aid to the democracies which dare to resist their aggression. Such aid is not an act of war, even if a dictator should unilaterally proclaim it so to be.

When the dictators, if the dictators, are ready to make war upon us, they will not wait for an act of war on our part. .61

In an attached note to the above annual message to the Congress, President Roosevelt names who he is referring to as the dictators and aggressors. 
NOTE: In the decade since 1931, international lawlessness practiced successively by Japan, Italy, and Germany, has been casting a lengthening shadow over the world. Repudiation of solemn treaty pledges, invasion of independent countries, bombing of civilians, enslavement of captive peoples--those are the principles which have seemed to guide the aggressor nations. 62

It would seem that the "confrontation-temperature" between the United States and Japan was nearly at the boiling point at this time. Both sides were becoming rather open in their statements about the errors of the other country. On January 15, 1941 at a hearing of the Foreign Affairs Committee of the House of Representatives, Secretary of State Hul1, in a speech concerning the Lend Lease bill, underscored the disturbing fact that Japan's leaders had openly declared their intention to achieve and maintain a dominant position in the entire region of the Western Pacific by force of arms. He also stated that they were trying to make themseives masters of an area containing almost half of the entire population of the world.

Secretary of State Hull told the members of this committee that Japan, Italy, and Germany all fit into the same category. They were all taking steps to "destroy the very foundations of a civilized world order under law and to enter upon the road of armed conquest... subjugation - - and - - tyrannical rule over their victims." Three steps were shown to have been taken by Japan that placed her in this category of countries.

The first step had occurred in 1931, said Hul1, when Japan had forcefully occupied Manchuria, breaking Japan's agreements as signatory of the Nine Power Treaty and the Kellogg-Briand Pact. The second step had been Japan's termination of the Naval Treaty of 1922 and her 
construction of large amounts of "military and naval armaments." The third step was Japan's "large-scale military operations against China" in 1937 and her establishment of "puppet-regimes" there.

Hull hardly held back any punches in this presentation to the House of Representatives' Committee. The language he chose to use was not highly diplomatic in style.

It has been clear throughout that Japan has been actuated from the start by broad and ambitious plans for establishing herself in a dominant position in the entire region of the Western Pacific. Her leaders have openly declared their determination to achieve and maintain that position by force of arms and thus to make themselves masters of an area containing almost one half of the entire population of the world.

Previous experience and current developments indicate that the proposed "new order" . . means, politically, domination by one country. It means, economically, employment of the resources of the area concerned for the benefit of that country and to the ultimate impoverishment of other parts of the area and exclusion of the interests of other countries. It means socially, the destruction of personal liberties and the reduction of the conquered peoples to the role of inferiors. 63

On January 21, Ambassador Grew sent a letter to the Secretary of

State informing him of the attitude and opinions some of the Japanese

leaders, namely Yosuke Matsuoka, had toward the United States.

Matsuoka had spoken to the Japanese Diet along with several other

leaders.

In discussing relations with the United States the [Foreign] Minister enumerated the embargoes and restrictions on exports to Japan since the abrogation of the commercial treaty. He stated that the situation had become so aggravated that Japan must now be adequately prepared not only to meet this pressure but to secure her economic life line within the area of greater Asia. In effect, he stated Japan's demands of the United States to be: (1) understanding of the vital concern to Japan of the establishment of an East Asia Co-Prosperity Sphere, (2) recognition of Japan's superiority in the Western Pacific, and (3) cessation of economic pressure on Japan.

Mr. Matsuoka then appealed for reflection on the part of the United States for the sake of peace in the Pacific and in the 
world: the Foreign Minister envisaged American entry into the war and the possibility of Japan being "compelled to enter the war" which would then bring about another world conflict.

For several days the press has suggested that the Foreign Minister would answer Secretary Hull's statement and a strong attack aimed at American policy was expected. The fact that the Foreign Minister's remarks were surprisingly mild and the fact that no Government statement had been issued in reply to Secretary Hull, although such a statement has been twice announced may indicate that careful consideration is being given within the Government to the avoidance of official utterances calculated to exacerbate American feelings toward Japan. 64

Matsuoka had been expected to make much stronger statements, but

Grew had believed, due to the urgings of other members of the Japanese Cabinet, he had been restrained for the time being from doing so. In view of other speeches made by Matsuoka, it is noticeable the caution used by him in this particular speech. An example of this caution is seen when one reads a portion of Matsuoka's speech to the Diet and sees him put his feelings in a very diplomatic way.

The United States has evinced no adequate understanding of the fact that the establishment of a sphere of common prosperity throughout Greater East Asia is truly a matter of vital concern to Japan. She apparently entertains an idea that her own first line of national defense, on the east, lies along the mid-Atlantic and, on the west, not only along the eastern Pacific, but even as far as China and the South Seas. If the United States assumes such an attitude, it would be, to say the least, a very one-sided contention on her part, and would cast reflections on our position of superiority in the Western Pacific, thus intimating that it betokens ambitious designs on our part. I, for one, believe that such a position assumed by the United States would not contribute toward the promotion of world peace. Speaking frankly, I extremely regret such an attitude of the United States for the sake of Japanese-American friendship, for the sake of peace in the Pacific, and also, for the sake of the peace of the world. It is my earnest hope that a great nation that is exerting such a tremendous influence in the world as the United States will realize her responsibility for the maintenance of peace, will reflect deeply on her attitude with fear of God, that is, true piety, will courageously liquidate the state of things created by the force of past circumstances and put forth her utmost efforts toward overcoming the impending crisis of civilization. 65 
The Foreign Minister's words of January 26 were more like the

Matsuoka who had claimed that the only way to gain respect from the

United States was to be "firm." Matsuoka could not hold back his

feelings concerning Hul1's speech of January 15, any longer. Grew

passed the "paraphrased" version of the text Matsuoka made to the Budget

Committee on to Hul1.

1. The time has passed for Japan and the United States to engage in arguments but since the interpellator has raised the question, certain points in Secretary Hull's statement requires clarification. His statement is based on erroneous thinking and his language is violent. The assertion that the Manchurian incident was the first step toward destruction of civilization is based on a superficial point of view. Rather the Anglo-Saxon support of the status quo in East Asia, except when such status quo was injurious to Japan, must be blamed. Chinese resistance must be in large part attributed to Anglo-Saxon encouragement. An extremely generous Japanese policy served only to make the Chinese think that Japan would suffer all insults. Traditional Japanese patience was finally exhausted and the Marco Polo Bridge attack carried out.

2. American statesmen do not want to understand Japan's policy. We are endeavoring unsuccessfully to urge the Americans to reflection. "Since the United States has no correct understanding of Japan's thoughts and actions we have no recourse but to proceed toward our goal. We cannot change our convictions to accommodate the American viewpoint. There is nothing left but to face America, though we sha11 continue without disappointment or despair to try to correct the fundamental misconceptions held by that nation."

3. During the tenure of the two previous Cabinets there seemed to be some effort on the part of theAmerican Government to reach an understanding with Japan. Mr. Hull is pardoned on this point. However, it has become evident that American conditions are the withdrawal of Japanese troops from China and abandonment of For?7 $50 \%$ curtailment of Japan's continental and southward advance policies. "Not one Japanese in the Empire would assent to the abandonment of these policies." This American demand is equivalent to Japan's offering friendship to America in return for abandonment of the Monroe Doctrine, admission that predominance in the Western Hemisphere is wrong and immediate granting of independence to the Philippines.

4. The United States seems to consider all of Asia and the South Seas as first line of defense. Japan's domination of the Western Pacific is absolutely necessary to accomplish her national ideals. "My use of the word 'dominate' may seem 
extreme and while we have no such designs, still in a sense we do wish to dominate and there is no need to hide the fact. Has America any right to object if Japan does dominate the Western Pacific?"

"As Minister of Foreign Affairs, I hate to make such an assertion, but I wish to declare that if America does not understand Japan's rightful claims and actions, then there is not the slightest hope for improvement of Japanese-American relations." Japn will still not give up the smal1 hope remaining that a change in American attitude can be brought about.

5. America's stiffened attitude may be partially attributed to an illusion that Japan's military power is weakened, and to the rumors that certain influential quarters in Japan secretly oppose the tripartite pact and say that Japan will not follow its obligations even though the United States should enter the war. However, the provisions of article 3 of the treaty will come into effect in almost every case except that of an overt German attack upon the United States. If the treaty is invoked after consultation of the three powers it is not believed that Japan will without reason take the narrow viewpoint and for its own selfish advantage remain an onlooker in the war even though it means staking the fate of the nation on the outcome. 66

These comments and those of the past weeks were not as upsetting to the United States as the actions of Japan in the Netherland East Indies and Indo-China were. This turned out to be another reason for muscle-flexing between Japan and the United States.

The Japanese mission to the Netherland Indies renewed a number of demands for special privileges which had earlier been denied. The Dutch made attempts to delay and postpone the Japanese demands. In Matsuoka's speech to the Diet on January 21, he had suggested that the Netherland Indies were part and parcel of the Japanese sphere. 67 There was not much assurance at this point that Tokyo would not at some early date attempt to take the Indies. 68

As far as Indo-China was concerned, January looked somewhat bleak. In December the French had broken into open hostilities with the Siamese because Siam was laying hold to her claims on the Mekong River. 
In January the French had met the Siamese Navy and had all but destroyed it. The Japanese had intentions of using these areas under dispute. Siam could be counted as being somewhat loyal to Tokyo, whereas the French were hardly loyal to the Japanese and would not easily allow them to take what they needed from French Indo-China. When the French were getting the better of Siam in battle, Japan attempted to intervene. On January 18, the Japanese military commander presented the Indo-China Government with demands for the conclusion of an armistice in which Japan made it very clear that refusal would bring about an ultimatum. On January 22, France agreed to negotiate with Japan. 69

The governments of Britain and the United States could hardly interpret these actions to mean less than further Japanese advances into southeast Asia. The forced mediation of Japan in the Indo-ChinaSiamese dispute appeared to be so much more evidence that grave events were in the offing.

Is there any wonder then that Ambassador Grew would write this portion in his diary reviewing the relationship between the United States and Japan.

February 1, 1941

One of my colleagues in Tokyo recently characterized the present situation in Japan as one of "unstable equilibrium." We can fully subscribe to the instability, but as to the equilibrium, that seems to be hardly the right word, and if the tilt is really held in balance, that balance is not obvious to the naked eye. It is true that the moderates are steadily working to maintain that balance, especially behind closed doors in the current sessions of the Diet, where committee meetings are being held in camera in order to avoid public censuring of the Government's policy. We know that Arita has been interpellating the Foreign Minister for days on end; we know that Hirota has said that Matsuoka is following a foreign policy "fatal to Japan"; we know, according to several prominent members of the Diet, that assurances have quietly been given by the Government that a policy aimed to avoid a clash with the United States will be followed. 
Yet in practice the southward advance is being pushed with all energy by the military; their stranglehold on Indo-China, in contravention of the agreement with Vichy, continues with ever-increasing intensity, while Japan's insistence on mediating the Thailand-Indo-China dispute and, according to reports, on being paid for such mediation by the acquisition of nava1 bases in Camranh Bay is patent evidence of her firm intention to acquire jumping-off facilities for an eventual attack on Singapore. "Equilibrium" between the moderates and extremists seems hardly the right word. The latter are firmly in the saddle, and in practice there is ample evidence that they intend to push rapidly ahead, obviously stimulated by the Nazis, either in the belief that the United States will remain quiescent or, if we do not remain quiescent, discounting the results of American intervention. The outlook for the future of the relations between Japan and the United States has never been darker. 70

During the vocalizations of mistrust and suspicion by both sides, the American government had attempted not to go overboard in its declarations against the Japanese practices. The policy the United States seems to have attempted to follow toward Japan was one of not appeasing, yet not provoking; rejecting Tokyo's claims to leadership in East Asia; puting a gradual end to the exporting of war materials except oil, and in some minds, the effect of sending American warships to Singapore to signify the intent of the United States siding with Great Britain, was contemplated. 71

In a letter to Grew in January, Roosevelt had told the ambassador the primary American concern, as he saw it, was to support Britain. Any action against Japan would depend on circumstances and capabilities. 72 The president followed this course by steadily enlarging the number of items placed on the embargo of American exports to Japan. At the same time he continued to allow aid to China. Roosevelt did not bend to British pleas that Americans should persuade the French to cecede land to the Japanese influenced Thailand. He turned his ears from the French 
pleas for assistance. Throughout the long negotiations between Siam and Indo-China, with the Japanese as mediators, the American government was careful to keep away from the dispute, and would not a11ow this a1tercation to influence them in their actions against Japan.

In general, the President seems to have shared the feeling of the State Department, particularly those of one of Hull's key advisors, Dr. Stanley Hornbeck, that the danger of a clash in the Pacific was not as great as Matsuoka's statements appeared to indicate. 73 Hornbeck had pointed out from a historical angle Japan when noisy was always bluffing and it appeared to him Japan only attacked when she stopped talking. In a memo of January 29, 1941, Hornbeck wrote if Washington permitted itself to be scared, Japan and Germany would gain their objective without war. He believed that it was an appropriate time to call Japan's bluff. "We should keep a11 the time in mind one big, outstanding fact, that Japan is not prepared to fight a war with the United States."74 Whether a bluff or not, the result was the same. Imperial Japan had not yet determined any irrevocable decisions and the Japanese statesmen were no less inclined than the American leaders to hope that a sufficient show of threat and "firmness" might gain their ends. On both sides of the Pacific the lines of policy had been clearly defined. Sooner or later, it would have seemed, that with both countries firming up their policies to the point of inflexibility, one or the other would have realized that the outcome would be war.

Only a radical change of course by one government or the other could now avert it [war]. Either the Japanese militants must abandon their determination to seize the hegemony of East Asia and the Western Pacific, or those in control of 
American policy must abandon the conviction that to yield that hegemony would be fatal . . to the American interest. 75

A test of nerves over whether to use American strength did occur in early February. On February 4, one American Naval attache in London was made aware of massive Japanese naval movements to the south of Japan. He forwarded this information immediately to the United States. Upon reception of this information, Roosevelt conferred with his military advisors upon courses of action to take. It was finally decided to do little more than offer to Admiral Nomura, the Japanese ambassador to the United States, some "long faces" and "moral" guidelines.

While this was transpiring, Great Britain had a frank talk with Ambassador Shigemitsu in London about Japanese movements to the south. Secretary Eden spoke to the Japanese ambassador and pointed out that ". . Anglo-Japanese relations were deteriorating rapidly, that Japan was more and more following the Axis line, and that evidently Tokyo was preparing for further action. - . If British territories were attacked, they would be defended with the utmost vigor."76

Great Britain, of course, wanted the United States to support them in their effort to stop the Japanese. Not much of any "physical" support was to be given. What did happen was somewhat of a mistake. Eugene Dooman, Counselor of Embassy in Japan, did give Japan a jolt which appears to have slowed her down. Dooman was known by the Japanese to be a firm and straight forward friend. It was thought, that upon his return to Japan after his brief tenure in America, his account of American opinion about the world situation would not be taken as a threat, but rather as advice. 77 
Dooman presented the Vice-Minister of Foreign Affairs Ohashi the American "philosophy" behind her stand in Asia affairs. Four major points concerning Japan, Britain and the United States were given. The first was that the American people were determined to support Britain even at the risk of war. The second, that if Japan or any country for that matter, menaced our effort to support Britain, it could expect conflict with the United States. The third, that if Japan were to occupy Dutch or British areas in the Pacific it would create havoc with the British position in the war. And fourth, that the United States had abstained from an oil embargo in order not to impel Japan to create a situation that could only lead to the most serious outcome. 78

Grew summarized the Ohashi-Dooman talks for Hull. It seems that they upset the Vice-Minister greatly.

Upon listening attentively to what Mr. Dooman described as the philosophy of the American position, Mr. Ohashi remained perfectly quiet for an appreciable space of time and then burst forth with the question "Do you mean to say that if Japan were to attack Singapore there would be war with the United States?" Mr. Dooman replied, "The logic of the situation would inevitably raise that question."

- - Circumstantial evidence that Mr. Ohashi was affected by the interview was given by Sir John Latham, the Australian Minister, who called on Mr。 Ohashi a few minutes after $\mathrm{Mr}$. Dooman left - . told me that he found Mr. Ohashi greatly agitated and distrait [distraught?.7

This frank appraisal of the American philosophy, it seems, was not urged by Washington D.C. but rather seems to have come from Ambassador Grew. The interesting point would have to be that Washington did not disavow the ambassador's and the counselor's efforts. This "February War-Scare," according to Winston Churchi11 in his Grand A11iance, was postponed ". . 1argely due to fear of United States."80 
The United States and Japan at this point in early 1941 should have sized-up each other's abilities to make threats and bluffs. If they had they would have found that the Americans were not prepared to war against the Japanese. Yet, President Roosevelt during these months boldly assumed that it was essential to bring Japan to a halt with the use of embargoes, naval blockades if necessary, with apparently little thought concerning what the Japanese could do physically to the American power.

Secretary of State Hull continued to lecture the Japanese diplomats with disdain as if the Pacific Ocean was merely a small lake in one of the states in America.

Had anyone in the United States calculated the difference in strength between Japan and themselves? Certainly the massive land size with a11 its raw materials, the technical knowledge, the skilled and highly productive population was superior to that of Japan. Yet, the United States had done very little to develop her military power. Her flex, her muscle-tone, was definitely inferior to that of the Japanese. The possibility of a conflict at the beginning of 1941 with not only Japan, but also with Germany and Italy was there for the United States. What was the strength of the United States? The Germans had approximately three hundred organized army divisions, the Italians about seventy, and the Japanese nearly one hundred-twenty, for a total of nearly five hundred divisions. The United States had twenty-eight. 81

Many of the Japanese divisions had received valuable combat training in China, while the Japanese Army on the whole had been at war on a large-scale operation for four years. The United States Army had virtually no experience. 
The Japanese Navy declared that their airforce numbered about four thousand aircraft, and it was believed the Army had a force about the same. The United States Navy's air force was sma1l and the Army's nearly non-existent.

America's strength abroad was even smaller. When Major General Wainwright arrived in Manila in late fal1, 1940, he took command of the Philippine Division. His force numbered seven and a half thousand. Assembled in Formosa was a force of Japanese numbering close to one hundred and fifty thousand men. 82

The United States did not agree with the policy of the "new order" and let Japan know of her displeasure and at the same time Japan let it be known that she did not appreciate the interference of the United States in a sphere that was of no concern to the Americans. At this. juncture in history in the early months of 1941, destiny had been set for a future conflict between the two countries. Or had it? Were there any chances for negotiations between the two countries that might reconcile the differences? Was there anything to negotiate? Was it too late? A man named Yosuke Matsuoka helps us answer these and other questions. 
CHAPTER I

FOOTNOTES

${ }^{1}$ United States Congress, Joint Committee on the Investigation of the Pear1 Harbor Attack, Pear1 Harbor Attack, Hearings Before the Joint Committee on the Investigation of the Pear1 Harbor Attack, Congress of the United States, Seventy-Ninth Congress (39 parts, Washington D.C., 1946), 1, (hereafter cited Hearings).

2 Ibid., 2.

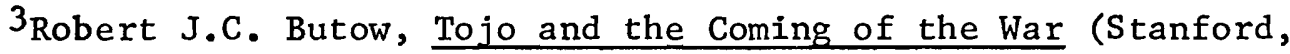
California, 1961), 28-30, (hereafter cited Butow, Tojo).

${ }^{4}$ United States Congress, Joint Committee on the Investigation of the Pearl Harbor Attack, Hearings, 1.

5 Ibid.

6Herbert Feis, The Road to Pearl Harbor (Princeton, 1950), 3.

7Butow, Tojo, 94 .

8 Ibid.

9F.C. Jones, Japan's New Order in East Asia: Its Rise and Fal1, 1937-45 (New York, 1954), 32-33, (hereafter cited as Japan's New Order).

$10_{\text {Ibid. }}$

$11_{\text {Butow, }}$ Tojo, 95 .

12 Ibid.

13 Ibid., 98.

${ }^{14}$ Ibid.

15 Ibid.

16 Ibid.

17F.C. Jones, Japan's New Order, 25.

${ }^{18}$ Ibid., $26-27$. 
19 Butow, Tojo, 91-94.

20 Ibid., 102.

21 Ibid., 102 .

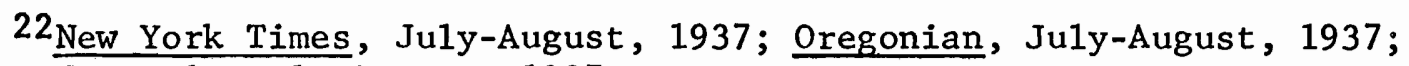
Oregon Journa1, Ju1y-August, 1937.

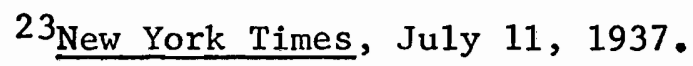

24 Oregonian, July 14, 1937 .

${ }^{25}$ New York Times, July 18, 1937.

${ }^{26}$ Corde11 Hul1, The Memoirs of Corde11 Hull (New York, 1948), I, 344-5, (hereafter cited as Memoirs).

27F.C. Jones, Japan's New Order, 51-52.

28 Ibid.

${ }^{29}$ Corde11 Hu11, Memoirs, I, 545.

30 Ibid.

31 Wi11iam Langer and Everett Gleason, The Undeclared War, 1940-41 (New York, 1953), 292.

32John Toland, The Rising Sun: The Decline and Fa11 of the Japanese Empire, 1936-1945 (New York, 1970), 44 .

33Langer and Gleason, The Undeclared War, 3.

34 Ibid.

35Feis, The Road to Pear1 Harbor, 28; Butow, Tojo, 137.

$36 \mathrm{Fe}$ is, ibid.

37 Ibid., 29 .

38 Butow, Tojo, 122 .

${ }^{39}$ Ibid.

40 Langer and Gleason, The Undeclared War, 3.

41F.C. Jones, Japan's New Order, 137.

42 But ow, Tojo, 122 . 
${ }^{43}$ Ibid.

44Jones, Japan's New Order, 137.

45 Butow, Tojo, 125.

46 Ibid. , 199-200.

47 Ibid., 154-5.

48Wa1ter Mi11is, This is Pear1! The United States and Japan, 1941 (New York, 1947), 13.

${ }^{49}$ Cordel1 Hul1, Memoirs, I, 633-34.

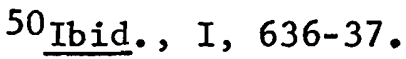

51 Feis, The Road to Pear1 Harbor, 13.

52 Ibid., $88-94$.

53 Ibid., 19; Butow, Tojo, 188-89.

54 Joeseph Grew, Ten Years in Japan (New York, 1944), 324.

$55_{\text {Walter Millis, This is Pearl! }, 16 .}$

56 Samue1 Rosenman, The Public Papers and Addresses of F.D.R.

(New York, 1950), IX, 633-44, (hereafter cited as F.D.R.).

57 Joeseph Grew, Ten Years in Japan, 359-61.

58 Ibid., 357-59.

${ }^{59}$ Ibid., 361-63.

60Millis, This is Pear1!, 28.

${ }^{61}$ Samue1 Rosenman, F.D.R., VIII, 663-75.

62 Ibid.

63Papers Relating to the Foreign Relations of the United States: Japan, 1931-1941 (hereafter cited as FR: Japan, 1931-41) (2 vols., Washington, D.C., 1943), II, 131.

${ }^{64}$ Foreign Relations of the United States: Diplomatic Papers, 1941, IV, The Far East (hereafter cited as FR: Diplomatic Papers, 1941) (7 vols., Washington D.C., 1956- ), IV, 8-9. 
65 Shepard Jones and Denys Myers, Documents on American Foreign Relations, July, 1940-June, 1941 (Boston, 1941), III, 260-67, (hereafter cited as FR: July, 1940-June, 1941).

66FR: Japan, 1931-41, II, 133-35. 267.

${ }^{67}$ Shepard Jones and Denys Myers, FR: Ju1y, 1940-June, 1941, 260-

68 Langer and Gleason, The Undeclared War, 317.

69 Ibid.

70 Joeseph Grew, Ten Years in Japan, 369.

71Langer and Gleason, The Undeclared War, 321.

${ }^{72} \mathrm{Grew}$, Ten Years in Japan, 361-63.

73Langer and Gleason, The Undeclared War, 321; Grew, Ten Years in Japan, 365 .

74 Ibid., 322.

75Walter Millis, This is Pear1!, 29.

76 Langer and Gleason, The Undeclared War, 323.

77Feis, The Road to Pear1 Harbor, 159.

78FR: Japan, 1931-1941, II, 138-43.

${ }^{79}$ Ibid., $137-138$.

80 Winston Churchill, The Second World War, Vol. III: The Grand Alliance (Boston: Houghton Mifflin, 1950), 179.

81 Walter Millis, This is Pearl!, 29-33.

82 Ibid. 
CHAPTER II

YOSUKE MATSUOKA

No single man had more influence on the Japanese-American route to war than Yosuke Matsuoka. Born in 1880 of a poor branch of the Choshu clan in Hagi, Japan. He was raised in an atmosphere of old Japanese clanism. At the age of thirteen he came to America to obtain an education. At the turn of the century in the United States, it will be recalled it was a time when outspoken hostility, insults, and agitation were directed toward the members of his oriental race. Staying in the home of a Presbyterian family in Portland, Oregon he went to grade school, high school and Oregon State Law School from which he graduated in 1900, at the age of twenty, with honors. In order to pay for his education, he had to work as a bus-boy, a waiter, a lumberjack, door-to-door coffee peddler, and an interpreter for a Japanese labor contractor on the railroads. He learned to speak English fluently and could do just as well in English as in Japanese, whether speaking privately or publicly. He remained in America until the age of twenty. 1 The results of the United States tenure on Matsuoka were evident later more in his actions against the United States than what he had to say about her. "Iife in the United States may have encouraged in him the habit of candid and unguarded speech, so unusual amongst the Japanese. Also perhaps, the wish to exert his will against us."2 Toshikazu Kase, a member of the Japanese Foreign Affairs Ministry during 
the time when Matsuoka was Minister of Foreign Affairs, recalled that:

For all his love of ostentation, however, Matsuoka was not vain at heart. He was a devout Christian, to begin with, and died a converted Catholic. He was a man of rugged honesty and homeliness and possessed of a sterling sense of honor. . . To the end of his days... he entertained a genuine affection for America. 3

"The American ideas that he had absorbed," wrote the Japanese Ambassador in London and later Foreign Minister, Mamoru Shigemitsu, "were neither of a pronounced right or left leaning." 4

As soon as he had won his law degree, Matsuoka returned to Japan. He prepared at that time to enter the foreign service. Passing the difficult diplomatic examinations, he was appointed Junior Consul in Shanghai in 1904. Before he left Shanghai, he had served for severa1 years as the Acting Consul Genera1. His ability at directing propaganda became very well known. On his return to Japan, he was appointed to the Information Bureau of the Foreign Office. In 1917, he became Secretary to the Foreign Minister; in 1918, Secretary to the Premier. He developed a reputation for his style of diplomacy. His did away with the traditional ways of diplomatic communication for a much more straight forward, to the point, type of diplomacy. In 1919, he received an appointment as one of the delegates to the Versailles Peace Conference. In 1921, Matsuoka was offered and accepted the position of Director of the South Manchurian Railway which later allowed him to go into politics because of his tremendous success, organization, and hard work in this position. 5

While in Manchuria he became aware of the financial interests Japan had there and in the areas of China. He also became we11acquainted with the key officers and leaders of the Kwantung Army. 
It was Yosuke Matsuoka who had the duty of speaking at the League in defense to what had been presented by the Lytton Commission. He defended the conquest of Manchuria. It was Matsuoka who had led the Japanese delegation defiantly from the Conference Hall of the League of Nations. 6 He rose to political fame in Japan and was a member of the parliament, which he later denounced and resigned his seat in the Diet. He formed his own political party which was opposed to the party system. He became a member of the "Show Restorationist," which planned to "save" Japan by making the people and the government more loyal to the Emperor. This group failed because in the public's eyes it was associated with the bloody mutiny of February 1936 in which many members of the government were assassinated. Yet Matsuoka never quit trying to develop a "single-party" whose goal would be "Neo-Nipponism."7

In the summer of 1940 a reformation of the present Japanese Cabinet came about. Six weeks prior to the fall of the Yonai Cabinet, Germany had spectacular success in winning on her European front. The Yonai Cabinet had come under the attack of the army which favored an alliance with Germany and Italy. The Yonai Cabinet was looked upon as favoring the present status quo of countries in Southeast Asia and as being friendly toward the United States and Britain. The army was not in agreement with the foreign policy that seemed to lean in the direction of Great Britain and the United States rather than toward Germany. The character of the Yonai Cabinet, top army officials had said, made the talks extremely "inconvenient" that were taking place with the Germans. The army believed the time was right for an alliance with Germany and Italy and at the same time, a different cabinet needed 
to be chosen. As a direct result of this dissatisfaction the Army was displaying, the Yonai Cabinet was forced to retire in mid-July 1940.8

On July 18, 1940 prior to the installation of the new cabinet, Konoye, Matsuoka, Tojo, and Yoshida met to come to an understanding in regard to national policies, both domestic and foreign, military plans, and political strategy. The Konoye Government emerged on Ju1y 22, 1940 in response to the demand for a powerful government. 9 The new Foreign Minister--Yosuke Matsuoka.

Mamoru Shigemitsu, Japanese Ambassador to England during this time, saw Matsuoka and Konoye as possible barriers to the demands of the Army to ally Japan with Germany. But instead of a barrier Matsuoka became the leader of both the militarists and the cabinet and took them wherever he pleased.

- - The principles he sto od for were those of a Japanese patriot. - . now at last, in the association of two liberal thinkers, Konoye and Matsuoka, Japan might keep the militarists in check and get back on the right track again. Matsuoka had valuable experience of our Foreign Ministry. . . . Many thoughtful people, including myself, expected great things of Matsuoka.

Alas that conditions falsified our hopes! Matsuoka was very ambitious. He hoped to follow in the footsteps of earlier great men of Choshu--Yamagata, Terauchi and Tanaka--and saw himself as the architect of a New Japan. Possibly the state of his health made him impatient to seize the chance to achieve his political ambitions while the general trend seemed favourable. In any case the result was disastrous to Japan.

He was in too great a hurry to get results. He wanted to be always in the vanguard, leading the Army, not as their plaything but as one who could mold them to his own uses. In the cabinet he assumed a role larger than that of Konoye himself. There was no room in the Japanese political world for two such outstanding men on the stage at the same time.10

Koichi Kido, genera11y known as Marquis Kido, "keeper of the sea1," and the Emperor's right-hand man, 11 saw Matsuoka as a garrulons, excited, 
untrustworthy person, who would eventually destroy the society of the wor1d, including Japan.

- - on approving the selection, the Emperor asked him to
Mivise Konoye "to be especially prudent in the choice of
Ministers of Foreign Affairs and Finance, in the light of
conditions at home and abroad." Especially prudent in the
choice of a Foreign Minister! It was to be Matsuoka. Loose
talking, always in a state of excited confusion, deceiving,
and unstable, he was the chosen medium for Saionji's parable:
"He eventually destroyed society completely."12

A member of the Japanese Foreign Office, Kase, was not quite as

severe about his impressions of Matsuoka as some. One notes a true

attempt at empathy for the Foreign Minister's "ways" or a complete

b1indness to them in an attempt to idolize the man he once worked for.

It is nowadays the fashion in Japan to blame Matsuoka for the breakdown of the negotiations with the United States. This fashion has gained popularity since Konoye in his memoirs treated Matsuoka as chiefly responsible in the case. Granted that Matsuoka's behavior was difficult to understand, it is unfair, to say the least, to distort the facts regarding him.

Matsuoka was a genius, dynamic and erratic. His mind worked as swiftly as lightning. People were dazzled by his brilliance. He was eloquent and could plead a cause with passion. Many were impressed by the vigor of his utterances and were carried away by them. But he often contradicted himself. Consistency to him was, as to Emerson, "The hobgoblin of little minds." He despised conventions and swept them aside as if they were cobwebs. This created the misapprehension that he was a radical. In short the personalities of Konoye and Matsuoka were poles apart. If Konoye was a shy squirrel sheltered in the deep forests, Matsuoka was the stormy petrel that delights to spread its wings over the foaming sea. It is doubtful if the two ever understood one another. 13

The impressions of the "new" Foreign Minister to those within the United States Foreign Affairs Department were considerably negative in nature. Secretary of State Cordell Hull writes about his first encounter with Matsuoka and how his distrust of the man who he had met in 1933 was to prove to be entirely correct. 
On March 31 I received Matsuoka as he passed across the United States enroute to Japan from Geneva. After leaving the League, Matsuoka had made unfriendly statements to the press concerning our country. I had little inclination to engage in a political discussion with him, and I so told Japanese Ambassador Debuchi. Bespectacled, with a black mustache, he looked like a businessman of his race, which he was. . - He was affable enough, did not try to discuss political matters, uttered a few casual words of greeting, and then rose to go. Once on his feet, however, he could not resist the temptation to make some political statement. He said he and his country regretted having felt obliged to quit the League. . . As he moved toward the door he said he did not want war to come between the two countries. He urged that Japan be given time in which to make herself better understood, and said he would undertake personally to do his full share toward this end when he reached home. I refused to be drawn into a discussion and merely wished him a pleasant journey.

When Matsuoka arrived home he received a public patriotic demonstration seldom seen in Japan. - . Later in the year Matsuoka resigned from the Seiyukai Party and from the Diet and proclaimed his opposition to party government, meaning his advocacy of a dictatorship. He was to prove one of our major enemies when he became Foreign Minister in 1940. It was while he was Foreign Minister that Japanese troops invaded French Indo-China and that Japan entered into the Tripartite Alliance with Germany and Italy aimed directly at the United States. My distrust of Matsuoka in 1933 was to prove correct. 14

When the Secretary of State found out about Matsuoka's position in the "New Konoye Cabinet" he wrote that Matsuoka had never shown the United States any reason for placing hope in him as Foreign Minister. If anything could be said about him it was just the opposite of trust and hope and that was distrust and pessimism for what he was able to do for the United States and Japan.

- - I had long considered him to be as crooked as a basket of fishhooks. He had led the Japanese delegation out of the Leage of Nations in 1933. He was committed, by statements and actions to the support of an aggressive imperialism. 15

Hul1 thought of Matsuoka as being the mouthpiece for Japan's "be11icose" statements. He believed Matsuoka should be called Japan's 
"bellwether."16 About the many loud statements he would make, Hu11 had been told by Ambassador Nomura that the Foreign Minister talked in this loud manner basically for home-consumption because he was politically ambitious. 17

The United States Ambassador to Japan, Joeseph Grew assesses Matsuoka and the "new" Cabinet as being distructive of any foundation the Yonai Cabinet had laid for better relations between Japan and America. This Japanese Government was headed down the road to Germany.

A typhoon could hardly have more effectively wrecked a foundation than the change of cabinet--with all that change implies--now appears to have accomplished. For at first sight the Konoye Government, interpreting popular and especially military demand, gives every indication of going hellbent toward the Axis and the establishment of the New Order in East Asia, and of riding roughshod over the rights and interests, and the principles and policies, of the United States and Great Britain. 18

The Ambassador records his feelings concerning Matsuoka's personal traits. Grew states that in his meetings with the Foreign Minister he discovered certain peculiarities about Matsuoka. One of them was quite obvious. He usually did most of the talking.

Matsuoka did about ninety-five per cent of the talking because his continuous monologues can be broken only by forceful intrusion. Although from time to time he brings up points of marked interest, his volubility flows on by the hour with little or no punctuation, and his discourses are therefore difficult to chronicle.19

Matsuoka's egocentric attitude was clearly observable when over several conversations with Grew he told that in attempting to find the perfect man for the ambassadorship in Washington D.C. his mind continually returned to himself. Grew writes that Matsuoka, - . has on more than one occasion said to me that of course he himself was the ideal man to go to Washington 
but that he couldn't be spared from Tokyo. So Nomura is clearly second-string! 20

On Matsuoka's "continuous monologues," Grew writes that only once before did he have to Iisten to such lengthy conversation and then that was several men in a row, not just one.

One emerges from such a conversation with one's head feeling like a whirlpool, for the Minister's volubility is surpassed in my experience only . . . as Under Secretary of State (to Turkey) when it was sometimes necessary to receive six or eight foreign diplomats in rapid succession and with no time to dictate the memorandums until afterward. . . 21

Ambassador Grew humorously jests about the personality of $\mathrm{Mr}$. Matsuoka when he surmizes how the conversations went between Matsuoka and Hitler. "I would give a lot to know whether Matsuoka managed with equal success to hold the floor in his talks with Hitler; it would take a superman to outtalk Matsuoka, but maybe Hitler is a superman."22

Yosuke Matsuoka returned home from the Soviet Union and Germany in mid-spring extremely happy about his considered success in signing a non-aggression pact with the Russians. His disregard for his fellow cabinet members was "aired" in a public meeting which gave the impression to Grew that he was trying to elevate his position by downgrading other ministers.

- . It is generally believed that his ambition is to become Prime Minister (God help Japan if he does) and that he will exploit his diplomatic successes to promote his personal interests.

But we learn on the best of authority that he is sailing very close to the wind. It is known that in his speech at the big public meeting to welcome him on his return he made several thinly veiled allusions critical of his cabinet colleagues. He indirectly charged them with willfully causing the breakdown in the system of commodity distribution. . . 23 
There was a part to Matsuoka's personality that seemed to estimate data in an exaggerated way, and if this was not happening, the other part of his personality seemed to be completely lost as to direction or details. In a Privy Council meeting of September 26, 1940, Matsuoka had been asked about the sphere of "Greater-East Asia," the term referring to the restructuring of the status-quo in relation to Japan. He answered quite candidly, "I mean the area which includes French Indo-China, Thailand, Burma, the Straits Settlements, and the Oceanic group comprising the Dutch East Indies, New Guinea, New Caledonia, etc."24 Matsuoka's use of the word "etc." certainly is some proof for his disregard for details. What was happening in the mind of Matsuoka or what was intended ". - at any given moment any guess seemed to be as good as another--so like a twisted rope was he." 25

The fact that Matsuoka could not be trusted was made by Grew to Hu11. Much of his problem was his incessant speech.

On the point of $\mathrm{Mr}$. Matsuoka's intellectual and political honesty I am reluctant to express a doubt. In the political maneuvering that constantly goes on in Tokyo he is sometimes quoted as saying one thing in one quarter while making a tota1ly divergent statement in another quarter. He talks so flowingly and freely, by the hour if time affords, that it is inconceivable that he should never make conflicting statements. 26

Some believed that Matsuoka's disregard for details, his seeming lack of direction, his blatant statements, all pointed to the fact that he was insane or at least moving in that direction. The secretary of the elder statesman Prince Saionji said to the Prince, ". . there are some who say Matsuoka must be insane..." The Prince, who was quite the philosopher, replied, "It will improve him if he becomes insane." 27 
Matsuoka definitely had some strange habits and methods. It is no wonder that so many found this man of many words unreliable and at the same time, one not to be trusted.

As one studies the actions and tactics of Yosuke Matsuoka, he cannot help but notice that the Foreign Minister was a power-minded individual who seemed determined to become the master of Japan's destiny Matsuoka had told Grew that he would direct the Foreign affairs of Japan regardless of the pressure placed on him by the Army. A non-negotiable condition of him becoming Foreign Minister was that he would . . "direct Japan's foreign relations, and he says he does not propose to let the military, particularly the hotheaded younger officers, dictate to him." 28

The military, as it can be shown, did not have much confidence in the dealings of their Foreign Minister. Even though he fit more the mold of the pro-Axis image the military had in mind for the Foreign Minister, they still realized that Matsuoka could be his own man when it came to making "important" decisions. One Japanese general described Matsuoka as "voluble and unconventional by nature," which were terms not too common nor complimentary to a politician. 29 Admiral Yonai, who Butow describes as being very prominent in and out of military circles, had felt that the Foreign Minister had "the good point of coming up with splendid ideas, but . . the fault of recklessly advancing in the wrong direction." Admiral Yonai went on to say that it was bad enough that Matsuoka did not judge matters objectively, but to take another step in the wrong direction of misunderstanding, he was blinded by the idea that his opinions were "absolutely correct" which made him "dangerous." 30 
When Matsuoka was going to Europe in the Spring of 1941, he had become outwardly so pro-German that even the Supreme Command feared what promises he might make to Hitler. Ambassador Shigemitsu remarked that:

Before Matsuoka left Tokyo there had been a conference at Imperial Headquarters on the subject of his visit to Europe. - . It was at this conference that the Supreme Command had impressed on Matsuoka that he should enter into no undertaking to attack Singapore and his military advisers had private instructions to watch over him to see that he kept the point in mind. 31

Matsuoka was driven somewhat by the Supreme Command, yet he was in contact with powers that were used to making decisions that affected their country's policies immediately. These contacts put much pressure on Matsuoka and he in return, it seems, attempted to comply properly. Matsuoka had a mind of his own and a real drive for power which the Supreme Command recognized and was concerned about. The Army and Navy became so concerned over Matsuoka's interpretation of the Foreign Minister's power to make decisions that they did not trust him and as a result kept constant watch over his "diplomatic affairs."

In an early meeting of the newly formed "Matsuoka-Konoye" Cabinet, Konoye was forced by Matsuoka's talk of advocating war with the United States to calm down the upset and alarmed Navy Minister Yoshida. Konoye attempted to calm the Navy Minister with these words. "To say something out of line and scaring others is one of Matsuoka's weak points."32 The problem, as far as the military saw it, was that they were not completely in charge of Japan. It was true that their influence upon the government was great, yet it is important to realize that it was not thorough. A cabinet or a minister could create havoc with the 
plans the military envisaged for the future of Japan.

If Japan had been a facist state or a thorough military dictatorship she would scarcely have hesitated to join in a pact with the Germans and Italians as early as 1939. But instead, being a monarchy with a "divine sovereign," real political unity to make that kind of a decision required one of the following

- Either the sovereign must possess autocratic powers and have the character and ability to use them; or government must be in the hands of officials, appointed by the sovereign and responsible to him, and they must be men of outstanding qualities of mind; or thirdly, there must be real parliamentary control of policy. 33

Japan during this time in history had none of these necessary ingredients. The issue of a German, Italian, Japanese pact within governing circles required, after more than a year of struggle, a cabinet with pro-German sentiments. The German Ambassador to Japan in frustration of not being able to obtain a pact, cabled that the "Japanese attitude must astonish the Axis, which is accustomed to unequivocal decisions, but it arises necessarily from lack of unified leadership."34

The military attempted and succeeded in "unifying" the leadership of Japan. They did this by taking on a new role which had its birth in the late $1920^{\prime} \mathrm{s}$. The role the Army played in directing pub1ic opinion and governmental support towards the "new order" and the German alliance was one of "uniformed politicians" showing the errors the nation of Japan had made in the past and what she was to do about them in the future. Admiral Yoshida writes that the primary objective of these "uniformed politicians" was to gain power. They did this by campaigning against the British and the United States' policies, by "eliminating existing social and political evils at home" and by advocating a "new 
order" in the Asian area of the world. This campaign created a following that grew in strength and power. It is this group of militarists that must take the blame, writes Yoshida, for driving Japan ". . . into the Axis camp" and precipitating the "greatest disaster ever suffered by the nation. For this--and the defeat and universal misery which their policies visited upon my nation--they must be held responsible. 135

The Supreme Command had taken over the power of the Emperor and the democratic form of government. Both powers had been weak and "there was room for an interloper to drive in a wedge." Mamoru Shigemitsu explains that the Emperor became a figurehead only to be used when needed by the true leaders, the Supreme Command. Constitutionally the Emperor in the past had the final word. In this situation brought about by assassinations, coups d'etat, and threats of violence, Yoshida remarks :

\footnotetext{
- - the military were released from the highest and final restraint, intended to keep them under control. In order to grasp the actual power, they preached the independence of the Supreme Command and the doctrine of nationalism, the theory that the Emperor was an organ of state was rejected and the entourage of the Emperor was even persecuted . . . inasmuch as they aimed directly and indirectly at the realization of military dictatorship, the fact is that the continuation of such measures brought about the accomplishment of their aims. 36

The shakeup in the cabinet brought about a "military-minded"
} majority made up of a group of men who had been associated with the armed forces or the administration in Manchuria. Because of this they reflected the views and aspirations of the pro-German alignment that the Supreme Command held.

Matsuoka, at the urging of the Army and those who supported the Army, took the moment of his appointment as the new Foreign Minister to 
make the most of his determination to go with Germany. He instituted a major purge of the Foreign Ministry positions that involved diplomats who opposed the pact with Germany or those who favored close relations with London or Washington D.C. He also put to use two pro-German men. He appointed Chuichi Ohashi, a member of the Manchurian clique, and Toshio Shiratori former Ambassador to Rome as special advisors. These men lent "assistance where it was needed most, busily flitted around behind the scenes."137

The Konoye Cabinet immediately drafted a program for action on July 26, and July 27. Two key documents came out of these meetings. The Outline of Basic National Policy, and Gist of Main Points in Regard to Dealing with the Situation to Meet the Change in World Conditions. 38

On August 1, 1940 the "Fundamental Policies of the Japanese Government" were announced to the world.39 The nations of the world were told that a historic turning point in the creation of "new forms of government, economy, and culture" were to be witnessed. Japan was one of the countries to watch, the declaration stated, and was "confronted by the greatest trial" she had ever experienced. Moving with the "inevitable trends in the development of world history," all parts of the Japanese government were to be rennovated in an attempt to perfect the "State structure for national defense."

The main objectives of these plans provided for an "unshakable national structure" which "conforms to the new world situation" on which Japan could "march forward toward the realization of the national policy by mobilizing the total strength of the nation." The settlement of China as usua1, was given first priority among the list of objectives. This in 
turn involved the "settlement" of southern problems: "to strengthen policies toward French Indo-China, Hongkong, and the Settlements, to check assistance to the Chaing regime and root out the feelings of enmity toward Japan." 40 A1so, so that Japan could obtain needed raw materials, "the diplomatic policy" toward the Netherlands East Indies needed reinforcement. 41 The "new" policy was thus stated:

1. Basic Policy

The basic aim of Japan's national policy lies in the firm establishment of world peace in accordance with the lofty spirit of Hakko Itiu, in which the nation was founded, and in the construction, as the first step, of a new order in Greater East Asia, resting upon the solidarity of Japan, Manchoukuo and China.

Japan will, therefore, devote the total strength of the nation to the fulfillment of the above policy by setting up speedily an unshakable national structure and stand of her own adapted to meet the requirements of new developments both at home and abroad.

2. National Defense and Foreign Policy

The Government will strive, in view of the latest world and domestic developments, for the repletion of armaments adequate for the execution of national policies, armaments founded upon the State structure for national defense organized in such manner as to bring into full play the total strength of the nation.

Japan's foreign policy, which aims ultimately at the construction of a new order in Greater East Asia, will be directed, first of all, toward a complete settlement of the China Affair, and to the advancement of the national fortune by taking a farsighted view of the drastic changes in the international situation and by formulating both constructive and flexible measures to meet these changes. 42

It was believed that this program would receive opposition from other powers, so preparations were made. The Konoye Cabinet decided "to foster a strong political tie with Germany and Italy, and to take active steps in the adjustment of diplomacy towards the Soviet Union while maintaining a firm front towards the United States."43

The policy of taking a "firm front" against the United States brought about a debate between the proponents, Matsuoka and the army, of 
such a stand against America and those who opposed, Konoye and the navy, such action in fear of Ame rican economic reprisals. Matsuoka succeeded in persuading those who opposed the stand by making a basic point. This was that just the mere fact of such an American threat of an embargo of essential supplies to Japan, was all the more reason for the government to "secure a free hand" in the southern regions. In order to obtain this "free hand," it would be necessary for Japan to ally with Germany and Italy, obtain an agreement of non-aggression with the Soviet Union, and above all else, take a "resolute position" against the United States. 44

On August 5, Matsuoka, in a letter to Shigemitsu, appears to have been quite confident that he could use the Axis Powers without committing Japan too much to their side. He told Shigemitsu that Italy would be subject to Germany but not Japan. Japan would be able to maintain her independence without losing it to Germany he reasoned, because of the geographical location of Japan in relation to Germany. Japan, wrote Matsuoka, should follow after". . an independent parallel policy, similar to that of the Soviet Union." He went on further to tell the Japanese Armassador, through the letter, that Japan should take advantage of the victories of Germany and move in on the territories that France, Holland, and Portugal controlled in the Far East. This way Japan would be making great territorial gains without any involvement in war. Matsuoka in this letter emphasized his belief that Great Britain would be thoroughly defeated by Germany and this would open the door to further possessions for Japan in the Far East. The United States could be kept from intervening by the threat of Japan's entrance into the war on the side of Germany and Italy. 45 
The misconceptions of this letter were the guidelines that Matsuoka pursued placing Japan in an awkward position between "two worlds." Matsuoka and his alliance with Germany established an "eitheror" situation for Japan. Japan would either risk everything in war on Germany's side or remove herself, with humiliation, from the obligations of an alliance with the Axis powers. 46

The man named Matsuoka, then fell into line with the desires and objectives of the "center," the army echelon that was made up of a nucleus of young powerful officers, and the "expansionists" who believed an alliance with Germany and Italy the answer to Japan's needs.

In late July it was felt within the Cabinet in Tokyo that a solution to the China Incident required good relations on Japan's part toward Great Britain and the United States. Matsuoka believed that a firm-bold stand was the answer in improving relations between these countries and his own. But at the same time, he argued that a war with the United States would result in destruction of the world. Since war with the United States was to be avoided, Matsuoka felt that his was all the more reason to improve relations with the United States. 47

The "firm attitude" that Matsuoka had in mind took further form in a four minister conference, September 4, 1940. The Matsuoka P1an, as it was called, was readily accepted by the other ministers. It proposed that the Japanese "new order in Greater East Asia" take, in addition to Manchukuo and China, the areas of French Indo-China, Thailand, Burma, British Malaya, British Borneo, the Netherland Indies, the former German mandated islands, French insular possessions in the Pacific, and India. The "plan" also made it extremely clear exactly what Japan's 
intentions toward the United States would be. Peaceful measures short of war would be used. But in the negotiations with Germany it would be noted that Japan had the right to make the decision to use force against the United States and Britain independently in accordance with the conditions at any particular moment. What this conference accepted from Matsuoka was that Japan would be able to do everything in her power to obtain acceptance of the demands for Japanese expansion without going to war for them. If she had to, it should be added, it seems very evident that she would use force to secure these countries. 48

The talks with the Germans began one week after the four-minister conference. The representative to meet with Matsuoka was Heinrich Stahmer a special German envoy. 49 The meetings were held in secrecy and they were numerous in sessions. Germany at this point had failed to persuade the British to beg for peace and was contemplating an attack on Russia. Stahmer let it be known to Matsuoka that they were not interested in Japan going to war against Britain, since that war was to be ended quickly. He wanted Japan's help in keeping the United States from entering and prolonging the war. Stahmer put it in such a way that agreement to an alliance was easy. The Alliance would only be used if an emergency came up between the three countries. Plus, if Japan and Russia could better their relationships, the alliance would be an effective barrier to the United States entering the war. 50

The army was in favor of such a tie-up but the navy had some reservations and wanted to study the matter further. Because of the feelings held by the navy, a liaison conference was scheduled for the fourteenth of September. Konoye discussed this matter with the "keeper 
of the seal," Kido. In this discussion Kido showed concern about the direction the country was moving. This, of course, was toward the German camp. Both he and Konoye had been disciples of Prince Saionjii, the elder statesman-philosopher. Kido had made it a practice of visiting the Prince at least once a month for nearly seven years just to listen to the old man give his views on happenings in Japan. During these talks, Saionjii had repeatedly taken the stand that Japan should base her foreign policy with that of the United States and Great Britain. Kido seemed to share this view and feared that an alliance with Italy and Germany would only result in a Japanese-American war. Matsuoka and Konoye discussed this with Kido and pointed out that the A11iance was a preventative step and if it was not taken, Japan would be isolated in the Pacific leaving themselves open to an almost certain attack from the United States. This response of fear concerning an American attack became the regular answer by those who favored the alliance toward those that disapproved.51 Under the firm pressure of Matsuoka, the cabinet and its members began understanding thatif Japan was to avoid a conflict with the United States an alliance with Germany was necessary. The navy dragged its heels.

The naval opposition to the Alliance was based mainly upon the portion of the pact which pledged all who signed "to assist one another with a11 political, economic and military means" if one of the signatories were attacked "by a power at present not involved in the European War or in the Sino-Japanese Conf1ict." The navy felt that this arrangement would plunge Japan into war. 
In the meeting of September 14, Matsuoka pointed out to the naval representatives that the question of peace or war would be decided by Japan. A tripartite pact would allow Japan to focus her attention upon the Chinese issue. A1so, Japan would be free for the first time from the danger of being isolated in the Pacific and the threat of being attacked by the United States would be removed. Matsuoka urged that "the conclusion of a tripartite alliance would force the United States to act more prudently in carrying out her plans against Japan." He had pleaded that in the long run the alliance would be the best way to block a war between the two countries. 52

So persuasive was Matsuoka that Konoye wrote in his diary that Matsuoka in the company of politicians began to cry out loud sobbing that it was he and Tojo who most longed for and arranged the alliance. 53 The leaders of the navy found it hard to agree with Matsuoka, yet due to his ability to persuade, the fear of Japanese reactionary groups who favored such an alliance and had been known to assassinate those who opposed their desires, and the threat of losing some of its military budget, it "had to respect the opinion of a responsible diplomatic specialist."54 Robert Butow writes of the Navy's change of heart: "The Navy apparently held this view even though Matsuoka's predecessor had strongly opposed the conclusion of a close military alliance." The predecessor had been a "diplomatic specialist" also. After the war the nava1 leaders who were being tried for war crimes recalled:

- . If Japan took an aggressive attitude toward the United States, the United States would be compelled to resort to equally aggressive measures, thus aggravating relations between the two countries to a degree where compromise would be impossible. 55 
This hindsight observation was not made at the conference of September 14, 1940. The opposition was under contro1. All that was left was to endorse the pact and send Matsuoka on his way to Berlin.

The endorsement came in an Imperial Conference of September 19, 1940. The fine points were thoroughly hammered out prior to this meeting, yet there were still some feelings of friction between the army and navy. Oil seemed to be the main point of contention. In reply to Matsuoka's comments on possible oil sources being the Soviet Union and the Netherlands East Indies, the Navy Chief of Staff, Prince Fushimi, asked:

May I interpret this to mean that there is, in genera1, no assurance that additional oil can be obtained? I will add that we cannot count on supplies from the Soviet Union. In the end, we will need to get oil from the Netherlands East Indies. There are two ways of getting it--by peaceful means, and by the use of force. The Navy very much prefers peaceful means.

Matsuoka replied in his convincing manner,

In negotiating the Pact, we paid most attention to the question of procuring oil. Even though British and American capital is involved, since it is under Dutch control we asked ott and Stahmer what Germany, which controls the Netherlands, could do to help us obtain oil from the Netherlands East Indies, and develop Japanese enterprises there in the future. They said that Germany could do a great deal.56

The oil need brought up a discussion on the alternative of using - force to obtain it and the effect this would have on the pact. A discussion followed that revealed Japan's attitude toward an "encirclement" by the United States. The Privy Council President Yoshimichi Hara asked Matsuoka,

- - supposing that the United States should lease bases in New Zealand, Australia, etc. and encircle Japan, we have thave we7 decided whether such an act should be interpreted as an American attack on Japan. 
Matsuoka answered,

The object of this Pact is to prevent the United States from encircling us in that way. The only thing that can prevent an American encirclement policy is a firm stand on our part at this time....

The President of the Privy Council retorted,

The United States is a self-confident nation. Accordingly, I wonder if our taking a firm stand might not have a result quite contrary to the one we expect.

Matsuoka's persuasiveness and logic are keenly shown in this reply.

I see your point; but Japan is not Spain. We are a great power with a strong navy in Far Eastern waters. To be sure, the United States may adopt a stern attitude for a while; but I think that she will dispassionately take her interests into consideration and arrive at a reasonable attitude. As to whether she will stiffen her attitude and bring about a critical situation, or will levelheadedly reconsider, I would say that the odds are fifty-fifty.

The final summaries of opinions were given by the army and the navy with approval of an Axis pact given by both. The navy in its concluding remarks seems to have alluded to some "loud-mouthed" talking by someone and a concern that "restraint and common sense" be used. The Navy

Minister Fushimi gave these final remarks.

The Navy section of Imperial Headquarters agrees with the Government's proposal that we conclude a military alliance with Germany and Italy. However, on this occasion we present the following desiderata: (1) that even though this alliance is concluded, every conceivable measure will be taken to avoid war with the United States: (2) that the southward advance will be attempted as far as possible by peaceful means, and that useless friction with third parties will be avoided; (3) that the guidance and control of speech and the press will be strengthened, that unrestrained discussion of the conclusion of this Pact will not be permitted, and that harmful anti-British and anti-American statements and behavior will be restrained. 57

Approximately one week later in a council meeting on September 26, a member pointed out that the United States so far had been holding back 
on her embargo of Japanese war materials lest pressure on her part would drive Japan into an alliance with Germany and Italy. Now with a pact Japan, instead of warning the United States to stay out of the war, might cause a reverse effect. The United States might be led to stiffen her attitude towards Japan which would lead to war and not to peace. 58 Matsuoka challenged this view stating that nothing could be achieved by friendly means.

If there is any means by which to check the deterioration of relations, and if possible, to improve them at all, that will be to assume what Minister Stahmer called a "determined attitude." For that purpose, it will be of the utmost importance to make as many allies as possible, and to proclaim it before the world as soon as possible thus strengthening our position against the United States. While keeping ever viligant eyes upon any repercussions which may arise from such a move on our part, I will try at the same time not to overlook any opportunity of restoring our relations with America to a more normal basis. The important point, is first of all, to show unmistakably a firm stand against the United States. 59

On September 27, 1940, the "pact of stee1" was signed in Berlin.

Because of its importance to American-Japanese relations the whole docu-

ment is reproduced here:

The governments of Japan, Germany, and Italy, considering it as the condition precedent of any lasting peace that all nations of the world be given each its own proper place, have decided to stand by and cooperate with one another in regard to their efforts in Greater East Asia and the regions of Europe respectively wherein it is their prime purpose to establish and maintain a new order of things calculated to promote mutual prosperity and welfare of the peoples concerned. Furthermore it is the desire of the three Governments to extend cooperation to such nations in other spheres of the world as may be inclined to put forth endeavours along lines similar to their own, in order that their ultimate aspirations for world peace may thus be realized. Accordingly the Governments of Japan, Germany and Italy have agreed as follows:

Article 1: Japan recognizes and respects the leadership of Germany and Italy in the establishment of a new order in Europe. Article 2: Germany and Italy recognize and respect the leadership of Japan in the establishment of a new order in Greater East Asia. 
Article 3: Japan, Germany and Italy agree to cooperate in their efforts on the aforesaid lines. They further undertake to assist one another with all political, economic and military means when one of the three Contracting Parties is attacked by a power at present not involved in the European War or in the Sino-Japanese Conf1ict.

Article 4: With a view to implementing the present Pact, Joint Technical Commissions the members of which are to be appointed by the respective Governments . . will meet without delay.

Article 5: Japan, Germany and Italy affirm that the aforesaid terms do not in any way affect the political status which exists at present as between each of the three Contracting Parties and Soviet Russia.

Article 6: The present Pact shall come into effect immediately upon signature and shall remain in force for ten years from the date of its coming into force.

At proper time before the expiration of the said term the High Contracting Parties shall, at the request of any one of them, enter into negotiations for its removal. 60

Japan had taken on a cause that was set against the United States.

This cause was much greater than her attacks had been against China. She had created a polarizing-action in the United States toward the British Camp. Secretary of State Hull attempted to hide his surprise in his statement of September 27, 1940 when he spoke to the press:

The reported agreement of alliance does not, in the view of the Government of the United States, substantially alter a situation which has existed for several years. Announcement of the alliance merely makes clear to all a relationship which has long existed in effect and to which the Government has repeatedly called attention. That such an agreement has been in process of conclusion has been known for some time, and that fact has been fully taken into account by the Government of the United States in the determining of this country's policies. 61

The shock of the pact was we11-hidden but still the unending 1ist of questions and interpretations of the meaning of the alliance began flooding in from various sources. What was "unwritten" in this agreement, it was feared, was that Japan had been given a "free hand" in Indo-China. 62 
The effect on the United States was one of shock in some circles and in other areas it was seen as a bluff. Those who had been urging the president to place an embargo on oil, Secretaries Stimson, Knox, Morgenthau, and Ickes, saw it as a golden opportunity to push harder for the embargo. In a notation in his diary Stimson wrote:

It is a very serious proposition of course, but it is so evidently evidenced by fear on the part of the Axis and so clearly represents only what they would do without a treaty, that I persona1ly have not been worried by it and I don't think the President has. If it should come to a showdown, at present and so long as the British Fleet lasts, the Axis in Europe could not help Japan if she got into trouble with us. So in substance the new arrangement simply means making a bad face at us. It will be pretty useful, I think, however, in waking up our people to the effect that at last they have got what they have been talking about--isolation. The United States is isolated except for one great power and that's the British Commonwealth, and I already see signs of a realization of this among the thoughtless. Clamours are being made for an alliance with Great Britain already. 63

Pressure to respond in some way or another to the alliance was mounting and growing in strength. In a letter to the President, Secretary Ickes wrote:

We didn't keep Japan out of Indo-China by continuing to ship iron, nor will we keep Japan out of the Dutch Indies by selling it our oil. When Japan thinks that it can safely move against the Dutch East Indies, and is ready to do so, it will go in regardless. It will make it all the more difficult for it to go in if it is short on oil and gasoline.64

Secretary Stimson made a record of the October 4, 1940 cabinet meeting where it was decided that the main purpose of the Alliance was to scare the United States out of supporting Great Britain. It was decided to remain silent in word for the time being but to act in deed immediately.

- . The President spoke very seriously on the situation that confronts us with the agreement between Japan and Germany and Italy. Japan has already begun to checkmate and we had a long 
discussion of what our action should be. Everybody agreed that the purpose of the three axis powers was to scare us out of giving material aid to Great Britain, but the general consensus was that we make no reply--we should do no talking, but do some straight acting which will show Japan that we mean business and that we are not in the least afraid of her. Various plans were discussed. 65

Grew cabled Hull on October 9, with this message of "private and off the record" feelings and fears of the Vice-Minister for Foreign

Affairs of Japan.

For the first time in several weeks I went to the country on October 9, but the Vice Minister for Foreign Affairs (Ohashi) urgently requested me to return to Tokyo so that he might see me, without delay, on behalf of the Minister for Foreign Affairs. We talked for about an hour and it was evident that the Foreign Minister is worried on two points: (a) reports received by him through Suma that a total embargo against Japan has been decided upon by the Government of the United States; and (b) reports from Washington that the evacuation of American citizens from the Far East has been "ordered" by the American Government. I stated that I had no information concerning the first point, and that with regard to the second, advice had been given to Americans in the Far East as a precautionary measure but no "order had been issued. The "embargo" on iron and steel scrap was referred to by the Vice Minister and I informed him of the substance of . . . the Department's telegram No. 383 dated October 8, 1940, 6 p.m. I had received this telegram a few minutes before the conversation.

That Japan desires peace with the United States and has no intention of attacking us, was a thesis dwelt upon at length by Mr. Ohashi. I said that the United States feels likewise toward Japan and that, as the Vice Minister knows, the American people are strongly peaceminded, but that both the American Government and people have been made less certain of Japan's real intentions by inflammatory utterances made recently by Japanese statesmen. I added that the American reaction to those utterances is exactly what should have been expected before the statements were made public, and I mentioned our preparedness program and the inevitable effect on it of the Japanese utterances.

Confidentially, I received the clear impression from the nature of the conversation and the marked urgency with which I was called, that the Minister for Foreign Affairs is seriously disturbed by the course of developments in the United States resulting from the Japanese Government's recent actions and statements. ..66 
The effect caused by the Tripartite-Pact could hardly be called a positive boost to United States-Japanese relations. The connotation taken was one of Japan selecting sides with the "fascist" countries of Europe. Polarization resulted.

Yet no drastic measures were taken by the Roosevelt Administration which had determined carefully to select its route in dealing with Japan. This was the case even though the Administration ". . burned with resentment at Japanese attempts to intimidate the U.S. . . "67 Grew records in his diary that this gesture was tremendously effective. The fact that the Japanese Foreign office presently sent out feelers to see how the United States was reacting was proof of this. It also showed Grew that to many Japanese the decision for peace or war was not necessarily going to be made in Tokyo.68 The ambassador later recalls that the only thing at this point that possibly would have stopped the Japanese course of action would have been an a11-out oil embargo.

But it was men such as Admiral Stark and General Marshall who were firmly opposed to any oil embargo. They realized that a confrontation was in the making between Japan and the United States. Yet at the same time, they insisted that it was inconceivable for the United States even to think of a physical encounter with Japan at this time. They also felt that it was more in the American interest to support Great Britain than it was to devote a major effort toward Japan.69 The oil embargo did not come immediately as a result of this alliance, but something did. On Columbus Day, Franklin Roosevelt made a speech which added to Winston Churchill's proclamations caused some sort of fear to rise in the hearts of the Japanese leaders. Roosevelt said: 
The Americans will not be scared or threatened into the ways the dictators want us to follow. No combination of dictator countries of Europe and Asia will halt us in the path we see ahead for ourselves and for democracy. No combination dictator countries of Europe and Asia will stop the help we are giving to almost the last free people now fighting to hold them at bay. 70

These warnings showed the Japanese that America was being drawn closer to assisting Britain by the pact and that any aggressive action on her part only would draw the two countries of America and Britain closer together. On October 10, 1940 Matsuoka apologized to the United States.

Lastly, I might add that the Tripartite Pact was not entered into with the intention of directing it "against" the United States. To state frankly, the parties to the Pact wished earnestly that such a powerful nation as the United States, in particular, and all other nations at present neutral would not be involved in the European War, or come by any chance into conflict with Japan because of the China affairs or otherwise. Such an eventuality, with all the possibility of bringing an awful catastrophe upon humanity, is enough to make one shudder, if one stops to imagine the consequences. In short the Pact is a pact of peace. 71

This retreat by Matsuoka was treated with considerable joy in the United States. The Chicago Daily News wrote, "Throughout the country there was much elation. . . Japan's 'bluff' had been called and Japan had executed one of the most precipitous backdowns in diplomatic history."72 A few days later Matsuoka invited the United States to join the Tripartite "Peace" Pact and to assist the Axis in making the world one large happy family. 73

The fact that Grew had mentioned Matsuoka was "deeply disturbed" by the American reaction to the Tripartite Pact gave relief to Washington. The course the President chose was not to push the American position with Japan too far. For the United States to impose the oil 
embargo or send her fleet further west might only provoke the Japanese to action. This, it was believed, could possibly lead to a loss of the Dutch Indies. The biggest concern was a military involvement by Britain and the United States in an area which was considered secondary to Europe. 74

In retrospect it appears that within the short span of time the "new" Knoye cabinet had been in power, the entire complexion of Japanese-American relations were altered. This time in history seems to be a pivotal point that led Japan down the "road of no return" which would lead to a collision with the United States. The sides had been selected. How much faith could the United States have in any future negotiations with Japan? Was she the future enemy?

The United States was encouraged to take action. Grew wrote that it was painful for him to see how far the relations between his country and Japan had deteriorated. Grew gave "Second Thoughts on Japan's adherance to the Axis." As he recalled that the month prior to the signing of the "Pact," many in Japan were fed up with Germany trying to stir up trouble between the United States and Japan. But with the leadership of Matsuoka and the army, the Alliance was drawn up for the "specific purpose . . of getting Japan and the United States into eventual war." The "better relations," that Matsuoka had verba11y declared to Grew he wanted between the United States and Japan, should be interpreted as relations that would allow Japan complete control of the Far East. This was what a "friendship" between the two countries would have to be based. Japan could no longer be looked upon as an individual nation, but instead she should be looked upon as a member of 
a team. The Konoye cabinet had shown its real intentions when it joined with Germany and Italy. The United States should not view this with complacency. With the forming of the Konoye cabinet writes Grew, - . we were given an undeveloped photograph negative, the general type of which we knew in advance but not the precise outline of the picture that would appear. Now the negative is pretty well developed, the picture is taking shape, and it is not the sort of picture to afford complacency with regard to the future relations between Japan and the United States. 75

Matsuoka it could be said was positive at the time of the signing of the Axis agreement that he had completely engineered a plan for world peace. His close friends found this agreement to be confusing to them in relation to their understanding of Yosuke's feelings and attitudes toward the United States. In discussing his rationale for the pact with his son, he said, "If you stand firm and start hitting back, the American will know he's talking to a man and you two can then talk man to man." This was in his thinking the best way to prevent war with the United States. This thought-process was based on his knowledge of what the American was like and how he reacted. Said Matsuoka, "It is my America and my American people that really exist. . . There is no other America; there are no other American people." He spoke to Doctor Yoshie Saito, one of his Foreign Ministry advisors, concerning this rationale. "I admit people will call all this a tricky business," but he had joined with the Axis "to check the Army's aggressive policy . . and to keep America warmongers from joining the war in Europe. And after that we can shake hands with the United States." This would keep peace in the Pacific and at the same time form a great group of 'capitalistic" nations around the world against "communism."76 
This rationale did have an effect on the United States-Japanese relations. A major problem is one of over-emphasizing the part Matsuoka played in the deterioration of relations. The stiffening of American flexibility toward the Japanese in part, during these times, was due to Matsuoka's rationale. There were many pressures that led Matsuoka to believe that his solution of "firmness" was correct. These ranged from the extremists in the Supreme Command all the way to the attitudes of racism in the United States toward the Japanese immigrants. Joeseph Grew put the responsibility for the Alliance on Matsuoka nearly two months after the signing of the pact. His diary of November 18,1940 reads :

With regard to the conclusion of the Tripartite Alliance. - . it was Matsuoka himself who put it through, bringing Konoye along with him. We are told on very good authority that other cabinet members were not consulted until the end and knew little or nothing about it. I now have it straight from a person closely in touch with the Imperial Court that the Emperor was most reluctant to approve the pact and was finally led to do so only when Matsuoka gave the Emperor his studied conviction that war with the United States would be inevitable if the alliance with the Axis were not concluded. Judging from Matsuoka's subsequent statements I think that this version rings true. 77

Whether Matsuoka was completely responsible for leading the Japanese into the Alliance is not as important as the effect the Pact seemed to have on the negotiations, the openness between Japan and the United States in the future to solve differences. A vindictive note can be made about "Matsuoka's masterpiece," the Alliance with Italy and Germany. The Tripartite Pact did alter the relations between Japan and the United States. It became a stumbling block to negotiations throughout the year of 1941. The concessions the United States would possibly think of making in allowing Japan a portion of the control of the Far 
East were shadowed by the implications the "Pact" cast on future relations between the two countries. Japan had obligated herself to go to war against the United States if the United States were to go to war against Germany. 78

What had been thought by Matsuoka, Tojo, and Konoye to be a method of keeping the United States from attacking Japan or keeping her from entering the European conflict was now causing the opposite to happen. The "pact" was creating in the American government a "firmer stance" against the Japanese. Alternative plans were discussed in Washington in thought of restraining American trade and exports to the Japanese. The use of armed force within the southwest Pacific was contemplated. The final result of the Alliance on Japanese-American relations was the United States drew closer to her Anglo-Saxon brother, Great Britain. 79

In the latter part of the month of January, Japan was in a quandary concerning the nation's next moves. At a Liaison Conference on January 30 , 1941 it was decided to move to the south and enforce mediation upon both Indo-China and Thailand. Japan wanted payment from both of them. She wanted the use of airbases, ports, the right to station troops, and the right to move troops throughout their land. If these countries failed to comply to Japan's demands, seizure would be the next step. 80

In the Tripartite pact, Germany and Italy recognized Japan's sphere of influence. Matsuoka did not believe this to be enough. He desired more time to get an understanding with Germany and the Soviet Union about Japan's move to the south. Japan needed to free herself from the conflict in China and most important, do away with the ill-feelings between the Soviet Union and Japan. This would in turn make Japan feel secure 
enough about her northern axieties that she could take after her desires to the south.81 The problem was a common one between Japan and the Soviet Union. This was China. China was receiving aid from Russia while Japan was in conflict with Chiang Kai-shek. Russia felt it necessary to keep the fire kindled between China and Japan with her financial aid so that Japan, her traditional enemy, would be kept busy. Japan was prepared to make things right with the Soviet Union so that the aid to China would be cut off, forcing Chiang Kai-shek to accept the Japanese terms ending the "China Incident."

Two methods were available to Japan to quiet the antagonism between her and Russia. One was a non-aggression pact, the other alternative was to get the Soviets to adhere to the Tripartite Pact and divide the spheres of influence into four parts rather than three. ${ }^{82}$ The alternative of Soviet adherance to the "Pact" was attempted as early as October, 1940 in Moscow with very little success. The relations with the Russians remained the same. ${ }^{83}$

It was determined in the Liaison Conference of January 30 , that Matsuoka would visit both Berlin and Moscow. 84 Several questions needed answers before the Foreign Minister could be sent on his way. What guidelines was Matsuoka to have? What should be his objectives? A conference was called for February 3, to answer these questions. War Minister Tojo, later Prime Minister, through interrogations after the war said that the purpose of Japan sending Matsuoka was to bring hamonious feelings between the Axis powers and the Soviet Union. He said that it was intended to foster better relations with the United States because of the magnanimous power which would be created by the four major countries. 85 
In actuality, Matsuoka did not receive a set of rigid instructions informing him of what was expected in bringing about "harmony." The discussion of his trip centered around four problem areas with which the members of the conference wanted Matsuoka to deal. The first was whether the Soviet Union could be drawn into the Tripartite pact. Little did the conferees know about Germany's future plans for the Soviets at this point. Al1 Japan knew and was basing opinions on was what was conveyed when the Tripartite Pact was signed in the fall of 1940 . The second was to secure recognition of Japan's supremacy in the area called "Greater East Asia." The third dealt with the price for harmony between the Axis powers and the Soviets. The fourth problem discussed, probably the biggest, was the man they were sending on this voyage, Matsuoka, who seemed to have a special allegiance to Berlin. The army and navy were concerned that Matsuoka might commit Japan to obligations that would be too binding. Because of this fear, Matsuoka was forbidden to make binding promises about Japanese participation or possible participation in the war already in progress in Europe. 86

The Japanese ambassador to England believed that Matsuoka was the "brains" of the cabinet and that his extreme allegiance to Germany made some very distrustful of what he might do on this trip.

The moment seemed oportune for Matsuoka to visit Germany and Italy, to establish close relations with their leaders, to study for himself how far the Axis had already gone on the road to victory and to gather data for a decision as to the next steps to be taken by Japan. The Army urged him to make the trip and Matsuoka himself thought it would afford an extremely favourable opportunity for him to consolidate his future political standing.

One further means of ensuring the Axis victory was closer relations with Russia... At the same time, for various reasons, there was some considerable opposition to Matsuoka's trip. In particular the Navy was anxious that, having absorbed 
military ideas, he should not go out of his way to promise an attack on Singapore, which Germany ardently desired. He was particularly requested, therefore, to make no commitments of a military nature. For that matter both the Army and Navy absolutely refused to allow anyone else to discuss questions affecting the Supreme Command. 87

The distrust he1d for Matsuoka stemmed from his "voluble and unconventional nature" and his German-fed idea that Japan should attack Singapore throwing herself into the war against Great Britain. This was a move that had implications which appeared to the military above and beyond Matsuoka's ability to comprehend. 88

Matsuoka was able to avoid purposefully any explicit instructions. Genera1 Tojo revealed in his post-war trials that "he did not trust Matsuoka's traits and personality and feared he might commit Japan to military operations. 189

Matsuoka was elated about the trip and went directly to German Ambassador Ott in Tokyo, to convey that the mission had been approved. He told ott of his plans to talk to Hitler about the attitude of the Tripartite Pact toward the United States. He wanted to prevent the United States entry into the European war if possible by diplomatic pressure, but if this failed, he told Ott, then Japan would agree to attacking Singapore. 90 This, of course, was a forbidden commitment according to what had just been told Matsuoka in the conference.

The German Ambassador to Japan, Oshima met with the Foreign Minister of Germany, Ribbentrop on February 23, where he was told by the Minister, that it would be to the Japanese interest to enter the war immediately, without warning. "The decisive blow would be an attack on on Singapore - . it must be carried out with lightning speed and if at 
al1 possible without a declaration of war. . ." The Foreign Minister gave Oshima no indication that problems had developed between the Soviet Union and Germany. In fact, Ribbentrop told Oshima that Russia had indicated a readiness to adhere to the Tripartite Pact. 91

On March 5, a military directive was sent out by Hitler to his top officials that shows how useful Japan was in the "total picture." It also proves that Germany chose not to trust any "secrets" to Japan.

It must be the aim of the collaboration based on the Three Power Pact to induce Japan as soon as possible to take active measures in the Far East. . . The Barbarossa operation will create most favorable political and military prerequisites for this.

The seizure of Singapore as the key British position in the Far East would mean a decisive success for the entire conduct of war of the Three Powers. In addition attacks on other systems of British Naval power--extending to those of American naval power only if entry of the United States into the war cannot be prevented--will result in weakening the enemy's system of power in that region. . . .92

The "Barbarossa Operation" was the code for Germany's, plan to attack Russia. Hitler was advised to tell Japan of his intentions, but refused on the grounds that he could not trust Japan. He believed Japan would misuse the information in dealing with the Soviet Union and try to strike a bargain with her. As Feis puts it, "Japan was not to be regarded as a reliable partner."93

When Matsuoka was being given a we11-attended send-off on March 12 , from the Tokyo railroad station, the train ready to leave, he attempted to find the answer once more from General Sugiyama when the army was going to take Singapore. The General replied, "I cannot tell you now." Colonel Yatsuji Nagai was sent along by the army as a "watch-dog" to see that Matsuoka made no rash promises about Singapore. 94 
Matsuoka, staff, and Ambassador Ott arrived in Moscow after an eleven day railroad journey to a "correct but reserved" reception.95 One of the first tasks Matsuoka set out to accomplish was a discussion with the United States Ambassador in Moscow, Steinhardt. A portion of this discussion shows Matsuoka's ability to talk out of both sides of his mouth. His discussion was a positive one with the American ambassador.

Matsuoka was emphatic in stating that under no circumstances would Japan attack Singapore or any of the American, British, or Dutch possessions, and he was insistent that Japan has no territorial ambitions. Japan, he said, was ready at any moment to join the United States in a guarantee of the territorial integrity or independence of the Philippine Islands. . . . He said that Japan would not go to war with the United States, and added that from his reading of American history it appeared that it was the United States which went to war with other countries; if a conflict should take place, it would come about only as the result of affirmative action by the United States.

- - Matsuoka said that now was the time when statesmen should take decisive action and that it is the "big things, not the little things" that matter; in his opinion the President is afforded a splendid opportunity "to clear up the entire Far Eastern situation" by discussing with Nomura the terms on which the war in China could be brought to a close. He added that he wished the President and theSecretary of State would trust him; on his record over the past few years, he said, he did not blame them for not having confidence in him, but that if they would give him the opportunity he would prove to them that Japan had no territorial or economic ambition, and that if an understanding were reached regarded by us all as reasonable he would fight to put it through should any elements in Japan oppose it. . . .96

No records were kept for history during the Molotov-Matsuoka meeting. The importance of the meeting was accented by the presence of Stalin who had not involved himself with a Japanese diplomat since 1928.97 Matsuoka later related to the Germans his version of the meetings. He said that he had proposed a treaty of friendship and nonaggression. Talk of terms for settlement followed with Matsuoka 
proposing the Soviets sel1 the northern part of Sakhalin to the Japanese. This caused Molotov to ask whether he was joking or not.98

Ambassador Shigemitsu writes of this time and explains the ground work a1ready accomplished by the Japanese ambassador in Moscow. - - when Matsuoka arrived in Moscow, the New Ambassador Tatekawa had taken up his new post. He had already been working on the suggestion of a non-aggression treaty to guard Japan's rear but Russia had demanded various compensating rewards and no progress had been made. Matsuoka again broached the subject of a treaty but he got the same answer. 99

As so little was being accomplished in this talk, Matsuoka suggested that the talk on a settlement be resumed when he returned from Berlin. The problems were postponed and Matsuoka left "for Germany emptyhanded."100

He was received in Berlin with much clamor and diplomatic decor. This "welcome" was just the beginning. It appears that Germany was quite interested in the outcome of these meetings for Matsuoka was given considerable amounts of time with Hitler and his Foreign Minister during his stay between March 27 and April 4.

In these meetings, Hitler and Ribbentrop tried to convince Matsuoka how Great Britain was nearly defeated. He was told that Japan should grab hold of this "unique" opportunity to make war on Britain and assault Singapore. A quick move, he was informed, would eliminate any interference on the part of the United States.101 "Japan was now in a position to make a decisive stroke," Feis paraphrases the Germans' speech, "one that would hasten Britains collapse and prevent United States' aid from being effective."102 This move on Singapore, Matsuoka was instructed, would help Japan secure her "needed positions" for the 
New Order in Greater East Asia.103 ". . Such a moment would never return . . now was the most favorable time. . ."104 Matsuoka also told Ribbentrop and Hitler that in connection with his efforts to bring about the Tripartite Pact he had often intentionally given "the impression of having a pro-American or pro-British attitude in order to deceive his opponents."105

Hitler told Matsuoka that ". - if Japan got into a conflict with the United States, Germany on her part would take the necessary steps at once."106 He also told Matsuoka that Germany ". . would be more than a match for America, entirely apart from the fact that the Germany soldiers were, obviously, far superior to the American."107

Matsuoka could not pledge the Japanese to an attack on Singapore. He told the Germans the reasons for this were "problems" at home from the "intellectual circles" which seemed to have a definite influence upon "His Imperial Majesty" and the cabinet.

The Germans essentially got a promise from Matsuoka which said that he would do everything in his power to bring about an attack on Singapore and make Japan a part of the war. But it was obvious that Matsuoka had come to Berlin without the authority to tell Hitler Japan would attack Singapore or enter the war. 108 Yet, even so Matsuoka was an influence upon the outcome of policy in Japan because of his position as Foreign Minister. No doubt, these meetings with the Germans kindled the flame of pro-German attitudes all the more, leaving little room for successful negotiations with the United States.

In these meetings, the Germans discussed the Soviet Union with Matsuoka. It appears that Matsuoka was not hearing what was being said 
to him. Hitler was evasive on the Soviet topic for fear of Matsuoka using the information as a lever to obtain Japan's desired treaty with the Soviet Union. Ribbentrop had told Matsuoka that a non-aggression pact with the Soviet Union "probably would not altogether fit into the framework of the present situation."109

When the Tripartite Pact has been signed, Pravda, a key Soviet newspaper, had called it a "further aggravation of the war and an expansion of its realm."110 Ribbentrop had immediately assured Molotov, the Soviet Union's Foreign Minister, that it was directed entirely toward the United States. "The treaty of course, does not pursue any aggressive aims against America. Its exclusive purpose is rather to bring the elements pressing for American entry into the war to their senses. . ." It was also to make them see ".. that if they enter the present struggle, they will automatically have to deal with the three great powers as adversaries."111 Ribbentrop had even written a long letter to Stalin suggesting that the Soviet Union join in the Pact. The historical mission of the four great powers--the Soviet Union included with the Tripartite Pact members was to administer and direct future developments on a world-wide scale. 112

Even though German policy had changed concerning their relationship with the Soviet Union, Matsuoka could not see the "glaring inconsistencies" between what he was trying to accomplish in the Soviet Union and what the Germans had been telling him in these meetings. 113 Ribbentrop had conveyed to him the opinion that "in view of the general situation it might be best not to go into things too deeply with the Russians." He had told Matsuoka that he was not sure how relations 
would develop in the near future with the Soviet Union and that a conflict with Russia was always a possibility. Yet Matsuoka did not comprehend the information. Two possible reasons for Matsuoka's blindness to the facts are given. One was that he was so set on his own political ambitions in Japan that he would not allow the Germans to take away his diplomatic success with the Soviet Union. The second reason was that his mind was in disorder by this time and he was mentally incapable of comprehending the facts. 114

Matsuoka returned to the Soviet Union on April 7. He was immediately engaged in a three-hour discussion with Molotov. Again there were no official records made of the conversation except for what Matsuoka told the United States Ambassador. In essence, he had been told that Moscow's demands were so high, the Soviet Union really must not have been interested in an agreement. 115 What actually transpired is mere conjecture over the next few days. Feis proposes that Matsuoka did what Hitler feared. He used the information gained by his talks with Hitler and Ribbentrop to sway Stalin. 116 The matter was brought to a surprising end when on Sunday April 13, a disappointed Matsuoka went for a last visit to see Stalin. The non-aggression treaty was brought up again and this time by Stalin. Stalin suggested a compromise and Matsuoka immediately wired Konoye for approval from the Emperor. With great haste in Tokyo approval was given. The Neutrality Pact was drawn up to say that both nations would respect each others' "territorial integrity"; that neither would join in a conflict against the other; and that they would remain neutral throughout conflict. 117 
In addition to the Pact an added portion was signed called the "Frontier Declaration" which agreed to respect reciprocally the territory between Manchukuo and the Mongolian Republic.

A first hand account of the wild celebration that followed the signing is given by Kase.

After the pact was solemnly signed in the Kremlin we were treated to a sumptuous buffet. Wine flowed liberally and the conversation grew animated as toast after toast was proposed: to Emperor Hirohito, to Kalinin, to Stalin, to Matsuoka, to Molotov. . . Both Stalin and Matsuoka were quite drunk by the time the latter took his leave. In the midst of the drinking bout I consulted my watch and found that it was almost time for the international train on which we were to leave to start. Stalin smiled and walked briskly to Molotov's desk, took up the telephone receiver and spoke a few words. Then he told us, "Gentlemen, the train will wait for you as long as necessary." The drinking was resumed with vigor. This was the Slav dictatorship in action! 118

Kase also describes the farewells at the train station. Stalin makes an unprecedented appearance with a lavish display of fondness for the Japanese.

In those days Stalin never took the trouble to see off foreign guests. Therefore when the dictator appeared on the platform with us everybody rubbed their eyes. But most surprised of al1 were the Axis ambassadors! Stalin warmly embraced Matsuoka and even allowed photographs to be taken of the scene. In fact, he kissed rather promiscuously. Try as I could, even I could not escape his bear hug. Clearly the neturality pact was as much a gift of providence for the Soviet Union as it was for Japan. 119

Not everyone felt as Kase, some estimated that neither nation trusted the otherto uphold the neutrality pact. As 1ond as there were no conflicts there would be no problems remaining neutra1. 120

The effect the signing of the non-aggression pact had on the United States was summed up by the Secretary of State on April 14, as overestimated. It was an event that was of little surprise to American diplomatic circles. 
It therefore comes as no surprise, although there has existed doubt whether the two Governments would or would not agree to say it in writing. The policy of this Government, of course remains unchanged.121

Grew interpreted the Soviet-Japanese Pact to be multi-purposed. It "represented a great personal success for Matsuoka." It was "concluded chiefly for the effect . . it would exert. . on Germany, from the Soviet point of view, and on the United States and Great Britain, from the Japanese point of view." Fina11y, the pact gave Japan and her extremist elements, "those who advocate a vigorous prosecution of the southward advance," a "free hand" to do what they wanted with the nations to the south of Japan. What the pact did not do, wrote Grew, was to define "the policies and obligations" Japan and the Soviet Union were to have to each other. 122

It appears that Matsuoka believed he had made strides toward universal peace, for he believed that the neutrality pact would make Chiang Kai-shek sit up and take notice of Japan's new power arrangement and as a result, speed up his negotiations with Japan. He also thought it would strengthen Japan's position in keeping the United States and Great Britain from intervening in her Asian actions. 123

He was a proud conqueror returning with the spoils to his home. As the then Japanese Ambassador to England saw it, Matsuoka came home unaware of the inconsistencies he had been a part of. He had been too "wrapped in dreams of what he was going to do next. He always came back to the same conclusion that the mainspring of Japan's policy was the Alliance." 124

This conclusion that the Alliance was the mainspring of Japan's policy by Matsuoka had an obvious effect on United States-Japanese 
relations. He had allied himself personally to Hitler and the Gemans in such a fashion that he was unable to think in terms other than those that would aid the cause of the Alliance. These pro-Axis feelings, no doubt, had an effect on his attitude toward the negotiations between Secretary of State HuII and Japan's Ambassador to Washington, Nomura. While on his Moscow-Berlin tour, Matsuoka had not been aware of these meetings and what was being discussed. His desire to be in one accord with German desires would soon play a key part in the failure of the Hu11-Nomura talks. This desire to be in one accord with Germany was emphasized so heavily by Matsuoka in the months of May and June that the Japanese cabinet, especially those that represented the Supreme Command, believed he was usurping their power to determine the policy of Japan. This became a power struggle with Matsuoka who was hardly a match for the powerful Supreme Command. 


\section{CHAPTER II}

\section{FOOTNOTES}

$1_{\text {Mamoru Shigemitsu, Japan and Her Destiny: My Struggle for Peace }}$ (New York, 1958), 196-97; Tochikazu Kase, Journey to the Missouri, trans. David Rowe (New York: Simon and Schuster, 1956), 43; Johannes Stee1, Men Behind theWar (New York, 1943), 367-68.

2 Feis, The Road to Pear1 Harbor, 80 .

${ }^{3}$ Kase, Journey to the Missouri, 43.

${ }^{4}$ Shigemitsu, Japan and Her Destiny, 196-97.

${ }^{5}$ Ibid.; Stee1, Men Behind the War, 367-68.

6Feis, The Road to Pear1 Harbor, 80-81; Stee1, Men Behind the War, 369.

${ }^{7}$ Stee1, Men Behind the War, 370.

${ }^{8}$ Chitoshi Yanaga, Japan Since Perry (Hamden, Connecticut, 1966), 540; Butow, Tojo, 139.

${ }^{9}$ Yanaga, ibid.

${ }^{10}$ Shigemitsu, Japan and Her Destiny, 196-97.

11John Appleman, Military Tribuna1s and International Crimes (Estport, Connecticut, 1954), 239.

12 Feis, The Road to Pearl Harbor, $80-81$.

13 Kase, Journey to the Missouri, 43.

${ }^{14}$ Corde11 Hu11, Memoirs, I, 272-73.

15 Ibid., II, 980.

16 Ibid.

$17^{\text {Ib id. , } 990 .}$

${ }^{18}$ Grew, Ten Years In Japan, 324-25. 
${ }^{19}$ Ibid., 344.

${ }^{20}$ Ibid., 350 .

$21_{\text {Ibid. }}, 374$.

22 Ibid.

${ }^{23}$ Ibid., 385.

24Feis, The Road to Pear1 Harbor, 120.

25 Ibid., 164 .

${ }^{26}$ Ibid., 120.

27 Ibid.

$28 \mathrm{Grew}$, Ten Years In Japan, 345.

29 Butow, Tojo, 141.

30 Ibid., $141-42$.

${ }^{31}$ Shigemitsu, Japan and Her Destiny, 215.

32 Butow, Tojo, 143.

${ }^{33}$ Richard Storry, The Double Patriots: A Study of Japanese Nationalism (Boston, 1957), 241.

${ }^{34}$ Ibid., 249.

${ }^{35}$ Ivan Morris (ed.), Japan 1931-1945: Militarism, Facism, Japanism? (Lexington, Massachusetts: D.C. Heath and Co., 1963), 5.

${ }^{36}$ Shigemitsu, Japan and Her Destiny, 51-52.

37 Butow, Tojo, 160 .

${ }^{38}$ Langer and Gleason, The Undeclared War, 5.

39 Jones and Myers, FR: July, 1940-June, 1941, III, 253-54.

40Langer and Gleason, The Undeclared War, 5.

$41_{\text {Ibid. }}$

42Jones and Myers, FR: July, 1940-June, 1941, 253-54.

43Langer and Gleason, The Undeclared War, 5. 
44 Ibid.

45F.C. Jones, Japan's New Order, 194.

46 Ibid.

47 Butow, Tojo, 154 .

${ }^{48}$ Ibid., 161-62; Basil Collier, The War in the Far East: 1941-45 (London, 1969), 62.

${ }^{49}$ Feis, The Road to Pear1 Harbor, 115.

50 Ibid., $115-16$.

$51_{\text {Butow, Tojo, }} 163$.

52 Ibid., 165-66。

53 Feis, The Road to Pear1 Harbor, 116.

${ }^{54}$ Butow, Tojo, 166.

55 Ibid.

56Nobutaka Ike, Japan's Decision for War (Stanford, 1967), 8.

57 Ibid., 12-13.

58Langer and Gleason, The Undeclared War, 29-30.

${ }^{59}$ Ibid.

60FR: Japan, 1931-1941, II, 165-66.

61 $1_{\text {Ibid., }}$ 169; Corde11 Hu11, Memoirs, I, 909.

62Langer and Gleason, The Undeclared War, 34.

63 Ibid., 35 .

64 Ibid.

$65_{\text {Ibid. }}$

66FR: Japan, 1931-1941, II, 170.

67Langer and Gleason, The Undeclared War, 35.

68 Ibid.

${ }^{69}$ Ibid. 


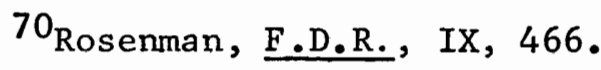

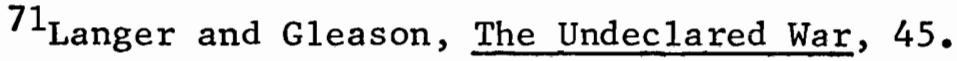

72 Ibid.

73 New York Times, October 14, 1940.

${ }^{74}$ Langer and Gleason, The Undeclared War, 45.

${ }^{75}$ Grew, Ten Years In Japan, 349.

${ }^{76}$ Toland, The Rising Sun, 64.

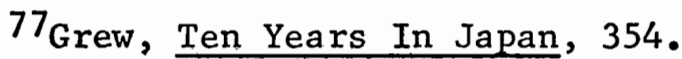

78Wa1ter Millis, This is Pearl! , 19.

${ }^{79}$ Feis, The Road to Pear1 Harbor, $122-132$.

80 Ibid., 181 .

${ }^{81}$ Langer and Gleason, The Undeclared War, 290.

82 Ibid.

83Ibid., 290-91; Feis, The Road to Pear1 Harbor, 181.

$84 \mathrm{Fe}$ is, Ibid.

85Butow, Tojo, 205.

86 Ibid., 205-6; Feis, The Road to Pear1 Harbor, 180-185.

${ }^{87}$ Shigemitsu, Japan and Her Destiny, 211.

$88_{\text {Butow, Tojo, }} 206$.

89 Feis, The Road to Pearl Harbor, 181.

$90_{\text {Ibid. }}, 182$.

$91_{\text {Ibid. }}$

92 Ibid., 183.

93 Ibid.

${ }^{94}$ Toland, The Rising Sun, 65.

95Langer, and Gleason, The Undeclared War, 347. 
96FR: Japan, 1931-1941, II, 143-45.

97Langer and Gleason, The Undeclared War, 348.

98 Ibid.

${ }^{99}$ Shigemitsu, Japan and Her Destiny, 212.

100 Ibid.

${ }^{101}$ Langer and Gleason, The Undeclared War, 348.

${ }^{102}$ Feis, The Road to Pear1 Harbor, 184.

${ }^{103}$ Ibid.

104Yanaga, Japan Since Perry, 591.

${ }^{105}$ Ibid., 591-92.

106Feis, The Road to Pearl Harbor, 185.

107 Toland, The Rising Sun, 65.

108Feis, The Road to Pear1 Harbor, 185.

${ }^{109}$ Yanaga, Japan Since Perry, 592.

110 Toland, The Rising Sun, 64.

$111_{\text {Ibid. }}$

112 Ibid.

113Shigemitsu, Japan and Her Destiny, 213.

114Feis, The Road to Pear1 Harbor, 185.

$115_{\mathrm{Grew}}$, Ten Years In Japan, 381.

116 Feis, The Road to Pear1 Harbor, 187.

117 Foreign Relations of the United States: Diplomatic Papers, 1940-1941, III, The Far East, (hereafter cited as FR: Diplomatic Papers, 1940-1941) (7 vols., Washington D.C., 1956-) ), III, 291-92.

118 Kase, Journey to the Missouri, 159.

${ }^{119}$ Ibid.

120Feis, The Road to Pearl Harbor, 187. 
121 FR: Diplomatic Papers, 1940-1941, III, 293.

${ }^{122} \mathrm{Grew}$, Ten Years In Japan, 381-83.

123Yanaga, Japan Since Perry, 593.

124 Shigemitsu, Japan and Her Destiny, 213. 
CHAPTER III

HULL-NOMURA TALKS

Matsuoka did not play a direct role in the original Hu11-Nomura Talks, yet overtones of his influence were felt in an indirect manner. By the end of these discussions, Matsuoka's desires were fulfilled, by poor selection of Japanese representation in America and his tactic of evasive stalling.

The Hul1-Nomura Conversations of Spring, 1941 were basically an offshoot of the work of several non-entities in Japanese-American circles who had desired solution of troubles between the two countries which would avoid a very possible conflict which was apparent to the casual observer by this time.

There was, since the signing of the Tripartite Pact, a budding opposition to the Konoye Cabinet and mainly Foreign Minister Matsuoka. There was the fear that the Tripartite Pact would lead the two countries to war. From this fear, Ambassador Grew assessed the situation to be "rotten" within the Konoye Cabinet.

- . something is getting rottener in the state of Denmark. The new structure is not sitting we11, and a growing dissatisfaction is brewing. Even the War Minister himself announced the other day that the new structure need not be interpreted as taking all the joy out of life; he apparently sees the way things are going. There is much bickering and divided counsels and much talk that Konoye, who is hardly more than a figurehead, cannot last. The pendulum in Japan is always swinging; the moderates say that it will soon swing back toward normal, but I fear not. I fear that it must swing still 
farther toward the extreme, and that if Konoye falls, either through resignation or through a coup d'etat, he is likely to be succeeded by a military dictatorship, even by a sort of revival of the shogunate. ${ }^{1}$

One can only surmise that Matsuoka had strong backing in army circles and that the military extremists were in total commitment to the binding Pact. This Pact played an intricate part in Japan's future plans of moving south and military extremists were not about to lose the Cabinet which seemed to be bending to their wishes and every whim. There was no reason at this point to believe the "optimism" projected by the moderates in Japanese circles.

Sides were pretty well chosen in the winter months of late 1940 and early 1941. It was quite evident to those taking an interest in Japanese affairs that both militarily and diplomatically Japan was preparing for an expansion of their influence over Southeast Asia. This "provoked" a "counteraction" which created a firming of relations between "the United States, Britain and the Pacific Dominions, the Netherlands and China. . ."2 The Japanese must have been aware of the course the relations of these countries were taking in response to the Pact.

One attempt to improve relations with the United States by Japan was their selection of a new Ambassador. The Japanese government, it appears, chose to be represented by a retired admiral rather than one of their own professional diplomats. A point shown to be extremely important by Robert Butow. 3 Admiral Kichisaburo Nomura had met the President of the United States when the President had been the Assistant Secretary of the Navy. He had also been part of the Abe Cabinet in 
1939-40 which had made efforts to improve the relations between the United States and Japan. As a retired Admiral he was also conscious of the naval attitude about the war and its fleet. It was believed in Japan that he would not do anything hasty that would endanger the navy, his country and the United States.4 Grew charged that the United States got a second-string diplomat, one that Matsuoka had been trying to obtain for some time. Matsuoka attempted and finally succeeded in convincing Normura of Japan's need of him.

Matsuoka telephoned me that he had been successful with Admiral Nomura last night and that the Emperor had approved the appointment. . - I cabled Washington that Nomura, as a man of high personal character who through long association had my esteem and respect and as a former Foreign Minister was believed to be fundamentally friendly to the United States, should be personally acceptable to the American Government. Incidentally, Matsuoka has on more than one occasion said to me that of course he himself was the ideal man to go to Washington but that he couldn't be spared from Tokyo. So Nomura is clearly second-string! 5

The United States seems to have been pleased to have this man come, he was believed to be honest and sincere in his relations with the United States and it was known that he had opposed the Pact. 6 Yet Nomura would prove to be less than expected because of his inexperience as a diplomat.

In an American-Japan Society luncheon honoring the newly appointed Nomura, soon to leave for the states, Matsuoka spoke at length about Nomura's selection and United States-Japanese relations.

The appointment of Admiral Nomura, I may say, is an eloquent indication of what my Government have in mind in regard to Japan's relations with the United States of America. I owe it to candor to admit that the relations between our two countries are severely strained at this moment. Now, the causes that have brought about the present unfortunate deterioration are, of course, many and manifold, but the fundamental cause, let me be frank, is American 
misapprehension of Japan's aims and aspirations. I shall forego to explain at length our viewpoint, lest I should spoil your appetite. - . Contrary to impressions current in America and elsewhere, Japan is not waging an imperialist war of greed and aggression in China. It is not a war of conquest or covetous ambitions. We are engaged in a moral crusade. - - We are fighting not for destruction but for construction. We are endeavouring to initiate an era of enduring peace and unlimited prosperity based on justice equity and mutuality, in Greater East Asia where we firmly believe we have a great mission as the civilizing and stabilizing force. We stand for peace and order. . . . Any nation that desires to take a hand in this great task is welcome. But mind you, there shall be, "no conquest, no oppression, no exploitation under the New Order which we
conceive."7

Matsuoka had told the audience that the United States had completely misunderstood the intentions of Japan coupled with Japan's intentions on what she was going to do for the world cultures. Yet in the same speech a change of heart which strikes a discord with the first part of his speech on better relations between the two countries is clear:

We only desire, on one hand, to be left alone, so that we may carry on our constructive work unhindered, and on the other hand, to see the trouble in China and the war in Europe brought speedily to an end, without adding more participants, particularly such a powerful one as America. Imagine just for a moment that America joined the European war or came to a clash with Japan in the Pacific. What then? If any bit of human feeling or an atom of instinct for self-preservation is left in you, ladies and gentlemen, wouldn't you shudder at the very thought? Would not a kind of ice-water shoot down your spine?

There would loom up every chance of facing at last the Armageddon that would end in a total destruction of our culture and civilization. I do beseech my American friends to think twice, thrice, nay ten, hundred or thousand times before they take a leap that may prove fatal to all Humanity. In this connection, I wish to leave no doubt whatever in the mind of any American citizen of the fact that Japan is, and will remain, loyal to her Allies; that Japan's foreign policy will resolve in the future around the Three Power Pact as its pivot, as it did around the pivot of the Anglo-Japanese Alliance in the past when that Alliance was in force. This of course, implies no threat. It is a simple statement of truism, made in order to prevent possible misapprehension. For an illusion on an issue like this will buy no good to anyone. 
Yet if one reads on into the conclusion of this lengthy speech, there is confusion over the "rosy-pictured aspirations" that are the objectives of what Nomura is to do for the relations between his country and the United States.

- I pray most fervently, that he may successfully fulfill his mission which is to usher in a happier period of mutual trust and better understanding between our two great nations. - . Let us keep our heads clear and cool. Let us go slow and make sure... Is it too much for Japan to ask for so much of a minute, just half a century or even less, in which to prove herself to the world? Time is the great curer of human travail. Let us all have a bit of patience. This is my appea 1.8

The new Ambassador spoke that he and the Foreign Minister ".. were agreed to one thing from the first: the necessity of improving drastically the relations between Japan and America which have deteriorated so much of late."9

In giving theUnited States, as Matsuoka put it, a "drastic improvement," Japan did not give up one portion, one little bit of its program nor did she retreat in any way from her membership in the Axis. At the same time this speech was made it was announced that General Hiroshi Oshima, "notorious advocate of military cooperation with Germany," would go back to Germany taking the place of the "professional diplomat," Saburo Kurusu. 10

The uncertainty of Nomura wanting to take the ambassadorship in America and his own attitudes toward the real chances for success in those negotiations, show that he mistrusted Matsuoka and his talk of the possibility of working out smooth relations between the two nations. Feis shows evidence of Nomura's feelings about Matsuoka when he records comments by Nomura to one of his former naval colleagues that definitely 
show the mistrust to be true. Nomura speaking of Matsuoka, said, ". - he only observes the external appearance of matters" and "while the Japanese Army continued to insist on military power, the relations between Japan and the United States wi11 never be amicable."11 Feis claims that Nomura arrived in Washington D.C. as an ambassador without instructions. His only task, writes Feis, was to persuade the United States to accept and agree wholly to what Japan was doing. 12 Yet Shigemitsu gives an entirely different picture which he obtained from the Japanese Ministry of Foreign Affairs archives. Matsuoka had given Nomura a complete set of instructions. In these he told Nomura that "unless our policy is drastically changed, it would be a pure waste of time to seek an understanding with the U.S." over peace in the Pacific. Matsuoka wanted Nomura to operate all discussions with the United States' diplomats from the position that the Alliance was the center of all Japanese policy. An understanding with the United States was to be obtained that would prevent her "from making war on Japan or from taking part in the European War." If this could not be obtained and the United States were to become involved in a conflict with Germany, Japan would be loyal to Germany and "there must not be the slightest cause for doubt on this point." A new ideal was to be portrayed by Nomura. Japan's attacks on areas of the Far East were to be events of the past. The new motto and ideals were "no conquest, no oppression, no exploitation. -." A practical problem needed to be dealt with, when Nomura met with representatives from the United States, which pertained to "self supply" and "self sufficiency" for the nation of Japan in the region of "Greater Asia." This question and rationale was to be addressed to the United States. 
Japan is in the grip of a need to work out means of selfsupply and self-sufficiency in Greater East Asia. Is it for the U.S., which rules over the Western Hemisphere and is expanding over the Atlantic and the Pacific, to say that these ideals, these ambitions, of Japan are wrong? Cannot Japan be allowed even this? There is no idea of exclusion in our minds. Let the U.S. come to the Greater East Asia Co-prosperity Sphere and help us to develop it. Any misgiving that we might shut off the supply of rubber and tin that she requires is laughable. 13

It seems that Feis was correct in his interpretation of the Ambassador's objective. In reality, the instructions were sparse in "meaty-substance" and of little negotiable value.

During the months of April, May, and June, 1941, there were numerous talks between the Ambassador from Japan and the Secretary of State of the United States. How did these talks between HuIl and Nomura come about? Were they sponsored by Japan? By America? Were they accurately reported to each man's higher superior?

In December, 1940 the Bishop James E. Walsh, Superior General of the Catholic Mission Society at Marykno11, New York and the Father James M. Drought were in Tokyo investigating the state of their missions. During their inspections they came in contact with a member of the Co-operative Bank of Japan whose name was Paul Ikawa. In informal talks the Catholic priests impressed upon Mr. Ikawa how they felt about the relations of the two countries. He was so impressed with what the Catholic fathers had to say that he arranged a meeting with Foreign Minister Matsuoka. After a lengthy discussion with Matsuoka, the priests were asked to carry an unofficial communication to Washington. They were instructed that it could not go through normal channels for fear of Japanese extremists. 14 
The message they were to take to America, Matsuoka informed them, was made up by leaders and important men other than himself. The message suggested that Japan would withdraw from the Tripartite Pact, and remove her troops from China, restoring China's political and territorial integrity. ${ }^{15}$ Another point mentioned for them to take with them was exploration of the chief economic problems between the United States and Japan. 16 Bishop Walsh had met with Prince Konoye and the Prince had confirmed the allegation that this proposal originated with him. 17

Whether Matsuoka was sold on the possibility of success for such an "unofficial-communique" it is difficult to determine. There is nothing that even suggests that Matsuoka considered Konoye's secret proposal "feasible or desirable." Possibly Konoye used some pressure on Matsuoka to at least hear these men out. Grew in a telegram to Washington, dated December 24, 1940, pointed out that Konoye was never in favor of the Tripartite Pact or was he overly enthusiastic about what it was doing to the relations with America. 18

It seems that the Japanese Cabinet was somewhat supportive of establishing better relations with the United States. The communique was not only Konoye's wish but Admiral Nomura's, Baron Hiranuma's, General Tojo's, the Navy Minister's, and General Muto's. The army through General Muto had conferred with Father Drought and had assured him that it would support the proposals.19 The Japanese Diet had influential politicians who were privately criticizing Matsuoka's policy and what it was doing to American-Japanese relations. 20 
Grew described the reactions of a former foreign minister and premier to Matsuoka's policies and how dangerous these men though the Tripartite Pact was to Japan.

Former Foreign Minister Hachiro Arita played a leading part in heckling his successor, while former Prime Minister Koki Hirota went so far as to charge that the policy of the Tripartite Pact was ill-considered and might prove fatal to Japan. 21

There was a great concern then by members of the Diet and Cabinet in Japan that much needed to be done about relations with America. There was a growing, festering, risk of war. Words were being exchanged in the early months of 1941 that were created a general attitude between Japan and the United States that said something like ". . if that is how you feel about it, we have no other alternative but to prepare for a physical conflict with you." Secretary of State Hull accented this in his message of January 15, 1941, when he spoke to a committee in Congress in reply to Matsuoka's defiant messages given to the Diet.

It has been clear throughout that Japan has been actuated from the start by broad and ambitious plans for establishing herself in a dominant position in the entire region of the Western Pacific. Her leaders have openly declared their determination to achieve and maintain that position by force of arms... As a consequence, they would have arbitrary control of the sea and trade routes in that region. . . . It should be manifest to every person that such a program for the subjugation and ruthless exploitation by one country of nearly one half of the population of the world is amatter of immense significance, importance, and concern to every other nation wherever located. 22

The response to Hull's speech of January 15, in Japan was a storm of indignation especially on the part of Matsuoka. Grew believed that Matsuoka had been suppressed from giving his "true feelings" about the matter when on January 21 he addressed the Diet. He reviewed the facts 
that Japan would adhere to the Tripartite Pact, that there would be no change in the status of Manchukuo and China, that Japan was determined to realize her program in the Greater East Asia Co-prosperity sphere and that he regretted America's misinterpretation of Japan's intentions.23

Matsuoka unleashed his suppressed fury on January 26 to the Budget Committee on his interpretation of the relations between America and Japan. He said that Hull had a "superficial point of view," that the point of arguing had passed.

Since the United States has no correct understanding of Japan's thoughts and actions we have no recourse but to proceed toward our goal. We cannot change our convictions to accommodate the American viewpoint. There is nothing left but to face America, though we shall continue without disappointment or despair to try to correct the fundamental misconceptions held by that nation. . . The United States seems to consider all of Asia and the South Seas as first line of defense. Japan's domination of the Western Pacific is absolutely necessary to accomplish her national idea1s. My use of the word dominate may seem extreme and while we have no such designs, still in a sense we do wish to dominate and there is no need to hide the fact. Has America any right to object if Japan does dominate the Western Pacific? As Minister of Foreign Affairs, I hate to make such an assertion but $I$ wish to declare that if America does not understand Japan's rightful claims and actions, then there is not the slightest hope for improvement of Japanese-American relations. Japan will still not give up the small hope remaining that a change in American attitude can be brought about. 24

Matsuoka had stated that there was "small hope" in negotiating for a peace with the United States as he was sending Nomura off. Approximately at the same time he had been involved in the Walsh-Drought conversations. What belief, what amount of faith did he have in future relations with the United States, official or unofficial? Did he really believe that these talks would have any affect upon relations? Did he really believe that a man such as Nomura could change the attitudes of the two countries toward each other? Or was he so committed 
to the "Matsuoka Plan" of September 4, 1940 which had as its objectives and alliance with Germany and relations with the United States just short of war so that Japan could attain her goals of a Greater East Asia Co-prosperity sphere? Were there ever any possibilities for negotiations?

The American attitude at this time about the Far East was not to appease the Japanese in any way, yet at the same time, not to provoke them. It was to hold up the status quo by rejecting Japanese claims to her leadership position in East Asia. The status quo was supported in the guise of aid to China, embargoes on certain war resources.25 While the American government observed Japan taking over Indo-China, the attitudes concerning Japan worsened.

Frank C. Walker, Postmaster Genera1, early in 1941 had been contacted by Walsh and Drought on their return to the United States about the "unofficial" communication. Walker established a meeting for these men with the President and Secretary of State. 26

On January 23, the group met and Bishop Walsh handed a memorandum to President Roosevelt which stated that it could not be admitted officially American was having success in pressuring Japan with economic barriers and defense preparations. Unofficially, America was successful, and Japan was prepared to alter her position on China and the international scene to a more moderate stance. The memorandum reviewed the effect the "Extremists" had on Japan and how the conservative element of leaders, "Prince Konoye, Mr. Matsuoka, Count Arima, General Muto, etc. and the Emperor.. " would rather "lose the war in China than lose the domestic war to their own Extremists." It was pointed out in 
the memorandum that a loss of the China War with the very rea1 possibility of a conflict between the United States and Japan, the "radica1 nationalists, civil and military" would be put in complete control of Japan. If through diplomacy the economic and international position of Japan could be adjusted to please most Japanese," public opinion in Japan would restore the Conservatives to complete contro1." In order to bring about a reversal in the Japanese political structure, Japan needed the assistance of the United States. Cooperation between the two nations was a must. The Axis alliance was to be nullified and a new one, similar in structure, was to be created including the United States and Japan. This alliance would threaten Germany with Japanese and United States involvement if Germany extended her actions any further in the confines of the European war in action. The United States was to also help Japan settle the "China War" and remove China from the position of being a "military menace or a political menace" to Japan. A Far Eastern Monroe Doctrine was to be recognized by the United States making Japan the leader of the nations of this area. In turn, Japan would "grant a complete Open Door" to the United States. Representatives were to be selected immediately by the President to begin negotiation on this if the power of government in Japan was to be placed again in the hands of the moderates. 27

The discussion took two hours and then it was decided that Walsh and Drought should continue their informal contacts with the Japanese Embassy on a private basis and that these two men should "reduce to writing what the Japanese had in mind."28 The strictly confidential memo brought by these men did not appear promising to the President and 
Hu11. 29 The priests were to work in the future through Walker and Hu11.

In sending the memorandum to Hull on January 26, the President attached this question, "What do you think we should do? F.D.R."30 The State Department suggested to the President that the talks be postponed until the arrival of the new Ambassador Nomura. In a memo to the President dated February 5, 1941, Secretary Hul1 advised:

I doubt the practicability of proceeding on any such line at this time. It seems to me that there is little or no likelihood that the Japanese Government and the Japanese people would in good faith accept any such arrangement--at this stage. It also seems to me that, if through the good offices of this Government an arrangement were worked out which would extricate Japan from its present involvement in China, the likelihood would be that Japan would extend and accelerate her aggressions to the southward rather than that Japan would change her present course of aggression to one of peaceful procedures. At the same time, I fee1 that we should not discourage those Japanese who may be working towards bringing about a change in the course which their country is following. Admiral Nomura, Japanese Ambassadordesignate to the United States, is expected here soon. . . . We should not, I think, resort to other agents and channels before we have even talked with the Ambassador. . . 31

Approximately two months after the original meeting with Drought and Walsh, Secretary Hull was given a "Draft Understanding" by way of Postmaster General Walker. 32 Although the "fathers" were part of the group supposedly assigned to put "to writing," the basic author of the text was one Imperial Army Colonel Hideo Iwakuro. 33

Exactly why the Army chose to send a representative is explained by Robert Butow. It seems that Nomura believed the key issue between Japan and the United States was the China problem. On his journey to the American capital where he was to take his post, Nomura toured the continent in the Far East, visiting with numerous military personnel of 
high positions in Korea, Manchuria, and China. He discussed with the staffs his new position and attempted to get a feeling or "understanding' of the continental army's position concerning the formulation of foreign policy with the United States. Butow continues, this is "a revealing indication of the role of field commanders in the formulation of Japan's foreign policy in the period in question." With the understanding in mind that successful negotiations should be attempted with army support, Nomura returned to Tokyo and spoke with the Army Chief of Staff and the Vice-Minister of War asking them for the army's top leadership or the "center's" cooperation. In addition, Nomura asked for an officer with "a thorough knowledge of the China Incident, and of problems pertaining thereto, be sent to Washington to assist him." At this point in history, writes Butow, the Army had no reason not to want successful negotiations to go on with the United States. The Chief of the Military Affairs Bureau recommended to Tojo, the War Minister, that he order Colonel Iwakuro "to proceed to the American capital to help the ambassador in his difficult mission." So, at Nomura's request the colonel was sent along. 34

The question can naturally follow, why this man? While Bishop Wa1sh was in Japan, he had been sought out by a Tadao Ikawa, who was known to him as "friend and unofficial representative" of Prince Konoye. Ikawa, the director of the Central Agricultural and Forestry Bank, had revealed to Drought and Walsh peace proposals between their countries had come upon certain difficulties, but there was still some hope. He wanted these two to lend assistance "particularly in the matter of helping to get messages to and from the State Department in Washington 
and to and from the American Embassy in Tokyo."35 Ambassador Grew had been consulted and the message given to Bishop Walsh was that his help "might prove useful." He got the distinct impression that he was "more or less encouraged to perform this little function of helping to transmit information when need arose."36 Prior to this Walsh and Drought persuaded Ikawa,

that men of good will in both Japan and America could help bring about a peaceful settlement and showed Ikawa a memorandum calling for a Japanese "Far Eastern Monroe Doctrine" and a stand against Communism "which is not a political form of government, but a corroding social disease that becomes epidemic." 37

It appears that Ikawa believed what these men told him for he was fired up with enough enthusiasm about the idea of negotiations that he made arrangements for them to see Konoye and Matsuoka. It is quite apparent that Tkawa believed these men to be "official-unofficial" diplomats to Japan.

The talk of Drought and Walsh with other "amateurs in diplomatic affairs" contained a looseness on both sides because of an interest to create "an atmosphere favorable to negotiations." 38 It seems that

Ikawa assumed that the proposal had the backing of President Roosevelt. This assumption was probably because of Father Drought mentioning that he was acting with the approval of "top personnel" from the American government. 39 The concessions made by these "amateurs" probably were

"too extreme."

There is no doubt that Walsh and Drought had come away with a rather misleading view of the extent to which the Japanese government was prepared to compromise. They steadfastly remained hopeful despite the skepticism later expressed in Washington. At times their enthusiasm betrayed them into reporting, at third hand, trivial items which would have been of no significance even if they could have been verified. 40 
On one such occasion, the Secretary of State records in his Memoirs, some trivia told in seriousness that "Prince Konoye has hung on the wa11 of his private bedroom a photograph of President Rooseve1t." "41

The question asked about the Colonel can now be answered. Where does he fit into the puzzle? Colonel Iwakuro had been kept informed by Ikawa on all of the transactions he had with Walsh and Drought. He had been aware of what was happening ever since the first meetings.

Colonel Iwakuro, it was believed, was very influential in the war ministry. He had a background of intrigue and idealism, a necessary ingredient to solidify these discussions and put them into action. He believed that peace with America was Japan's salvation. Prince Konoye had recommended to Ikawa that he be in contact with "one of the most agile brains in the Army," Colonel Iwakuro. 42

The importance that needs to be stressed about Iwakuro and Ikawa was that they both believed the words of Walker, Walsh, and Drought to be "presidential-opinion." Everything that transpired in the discussions was accepted by the Japanese as being Roosevelt's ideas and if not his ideas at least he was aware of what was being said. In this atmosphere of "unrealism," Colonel Iwakuro took charge of writing the "Draft Understanding" which was presented to Hull on April 9.

Basically the document stated that Japan would pledge to use only peaceful measures in the southwest Pacific and that she would only go to the aid of Germany if that country were aggressively attacked. In exchange for this pledge America was to restore normal trade with Japan, help Japan obtain her needed raw materials from the southwest region of Aisa, influence Chiang to make peace with Japan on, naturally, Japanese 
terms, and to give friendly diplomatic assistance to the removal of the "British-influence" in the Far East. 43

Hu11 and the State Department advisors were disappointed for the document did not present what they had been led to believe it would. "Most of its provisions were all that the ardent Japanese imperialists could want."44 Herbert Feis makes the point that the State Department was extremely skeptical for they found the text to be "poor." It was not rich enough to even use as a bribe for protection against a Japanese move to the south. The "experts" from the State Department saw that it forced the United States to give up American aid to China and at the same time forced the United States to accept the Japanese terms. The United States would have to reverse her "embargo" tactics and see to it that Japan's growing military was supplied with needed materials. The main concern of the State Department was the Tripartite obligation Japan had and this was not even mentioned. 45

Why, if they were so disappointed, did they pursue the talks?

In the first place, Hull saw no purpose in rejecting the text without at least talking about it.

- - However objectionable some of the points might be, there were others that could be accepted as they stood and still others that could be agreed to if modified. The state of our relationship with Japan was such, and the requirements of our policy of extensive aid to Britain were such that I felt no opportunity should be overlooked that might lead to broad-scale conversations with Japan. 46

Hul1 obviously believed that there were more ways to deal with differences than war. Talk always had the possibility of settling differences. Because of this attitude of "talk could make the difference, if we but try," the Secretary of State asked Nomura to come to his apartment on Apri1 14. 
It is necessary to take an in depth look at these informal meetings of Apri1 14 and Apri1 16. One can find much that explains the failure and misunderstandings that appeared later from these first two encounters. One of the first items on Hull's agenda was to emphasize the fact that the "Iwakuro-Draft Understanding" was an "unofficial" proposal for a settlement between Japan and the United States.

I had been told that the Ambassador himself had participated in and associated himself with these plans. I repeated . . . that we could deal only with the Ambassador in considering the problems outstanding between our Governments, and I wanted to clear up the question of the extent of his knowledge of the document containing the proposals and whether it was his desire to present it officially as a first step in negotiations.

Nomura promptly replied he knew all about the document, he had collaborated to some degree with the various Japanese and American individuals who drew it up, and he would be disposed to present it as a basis for negotiations. He had not yet forwarded it to his Government, however, but he thought his Government would be favorably disposed toward it.

I said there were certain points my Government would desire to raise prior to negotiations, such as the integrity and sovereignty of China and the principle of equality of opportunity in China, and he could then communicate these to his Government and ascertain whether it agreed that there was a basis for negotiations. 47

On April 16, Hull asserts that he handed Nomura a "statement of four basic principles" which would have to be the foundation work that would have to be completed and accepted prior to any agreements made between the two countries. Hull added:

The one paramount preliminary question about which my Government is concerned is a definite assurance in advance that your Government has the willingness and ability to go forward with a plan for settlement. Is it willing to abandon its present doctrine of military conquest by force and of taking title to all propoerty and territories seized? Is it ready to give up the use of force as an instrument of policy and adopt the principles that my Government has been proclaiming as the foundation on which all relations between nations rest? 48 
The "four basic principles" were seen by Hull and members of the American government to be the foundation that a11 of the nations of the world were to establish their relations on. They were 1) respect for the territorial integrity and sovereignty of each and all nations; 2) support of the principle of non-interference in the internal affairs of other countries; 3) support of the principle of equality, including equality of commercial opportunity; and 4) non-disturbance of the status quo in the Pacific except as the status quo may be altered by peaceful means. 49

Hu11 had said to Nomura in this second meeting, "You understand that we both agree that we have in no sense reached the stage of negotiations; that we are only exploring in a purely preliminary and unofficial way what action might pave the way for negotiations later."50 Not until Japan had adopted these four principles would the United States even consider thinking about the "Draft Understanding." Then if the Ambassador to Japan submitted the "Draft Understanding," the "informal document" prepared by individuals outside of the State Department, and ". - his Government approved it and instructed him to propose it to us, it would afford a basis for starting conversations." From that point then the United States ". - would thereupon offer counter proposals and independent proposals," discussing them with Nomura, "along with the Japanese proposals, and talk them out to a conclusion one way or the other in the friendly spirit that unquestionably should and would characterize the conversations." 51

Nomura did not respond with an "I understand what you want me to do with the four principles." Instead he responded on several of the points of the "Draft Understanding." 
Despite Hull's pointed talk of the four principles, he was not certain Nomura had understood him.

I was not sure whether the Ambassador fully understood each statement I made in regard to the four points laid before him, and I sought to illustrate by saying to him that the principles underlying a good portion of the proposals in his doctrine were similar to the principles contained in the four points I had handed to him. . . I added that, if his Government should make up its mind to abandon its present policies of force and invasion, et cetera, and to adopt a peaceful course with worthwhile international relationships, it could find no objection to these four points reasonably applied . . . he could judge the United States attitude toward a Far Eastern settlement in the light of these practices and principles. 52

Nomura wanted Hull "to indicate" whether he would to a "fairly-

ful1 extent" approve the proposals contained in the "Draft-Understanding."

I again replied that there would be ready approval of several of them while others would have to be modified or eliminated and this Government would offer some independent proposals, but that if his Government is in real earnest about changing its course, I could see no good reason why ways could not be found to reach a fairly mutually satisfactory settlement of all of the essential questions and problems presented. 53

Nomura could hardly handle the English language and Secretary Hull,

"frequently doubted whether he understood the points" he was attempting

to make. "I took care to speak slowly and often to repeat and reempha-

size some of my sentences." 54

The end of the conversation of April 16, left Secretary Hull some-

what frustrated with Nomura's ability to hear and comprehend.

The Ambassador seemed not to understand why I could not now agree to some of these proposals in his document. I sought repeatedly to make clear to him, in the first place, that we have not reached the stage of negotiations, he himself agreeing that he thus far has no authority from his Government to negotiate; and in the second place, that if I should thus out of turn agree to a number of important proposals in the document and these proposals should be sent to Japan and the military or extremist groups should ignore them, I and my Government would 
be very much embarrassed. The Ambassador finally said he fully understood the situation and made clear, I thought, that he would proceed in his own way to consult his Government regarding the four points in the form of a question which I laid before him inferentially with respect to the approval by the Government of his document, by which is meant the document prepared by the group of Americans and Japanese here with the admitted knowledge and more or less cooperation of the Ambassador himself.

Hull assumed after the meetings of Apri1 14 and 16 that Nomura had sent the "Draft Understanding" along with Hull's "four basic principles" and comments to Tokyo. The next step was to await the Japanese rep1y. 56

What Nomura did with the information Hull gave him in these discussions is a mystery. "Not one matter of substance," writes Butow, "out of a11 that he had said, with care and purpose, was transmitted to the Japanese Government."57 Nomura simply took the proposal and sent it to the Japanese Foreign Ministry with a request for instructions and favorable responses. In a very lengthy and rather ambiguous sentence, Nomura explained that "behind-the-scenes maneuvers" concerning the "Draft Understanding's" parents and upbringing had been going on for some time; that the "approval" of the American government had been "sounded out"; that after his own "private participation" with Hul1, he was able to see that the Secretary of State had "on the whole, no objections" to the draft; and that as a result of Hull directing negotiations, the proposal had been "agreed upon."58 What a misinterpretation!

The reader is reminded that $\mathrm{Hu} 11$ 's intent was to have the Japanese deal with the four principles, then, if these could be accepted, the Draft-Understanding should be presented to the Japanese Government to see if they would want to present the proposal to the United States as 
a basis for starting conversations. Hull made it clear, at least in his writings, the reason he could not agree to points in the proposal of April 9 was because if he did and the "military or extremists" should ignore them, "I and my Government would be very much embarrassed."59 The way Nomura reported this was to imply that the Americans were eager to push ahead on the tenets of the proposal he was sending to Japan. "The Secretary had advised him, Nomura cabled, that the United States government would be placed in a difficult position if Tokyo should convey its disavowal after the conversations had been in progress in Washington." The implication made by Nomura that the "proposals" were an American product, that Hull had a hand in preparing them, and that the United States was taking the initiative to make the proposal was in the cable of Apri1 17, 1941. From this cable came the assumption that the "Draft Understanding" was American made. 60

The total background of the proposal's "behind-the-scene maneuvers" came as quite a surprise to the Foreign Ministry in Japan. Konoye had known through Ikawa what was transpiring in America, but Nomura had neglected to send word either to Matsuoka or to anyone in the Foreign Ministry. 61 But the greatest error was made when the Ambassador failed to mention that the "foundation for future negotiations," was Hull's four points. The "proposal" would no doubt receive favor from Nomura's "associates" since the proposal was written mainly by Colonel Iwakuro. But the reception for Hull's four points would be something entirely different. The possibility of Konoye carrying the cabinet's and the army's acceptance of the proposal was still only a possibility. Matsuoka was about to arrive home from his "triumphal tour of Europe," 
and would probably have a lot to talk about. There would, no doubt, be a real debate over the Hull-Nomura discussions upon Matsuoka's return.62 So why should Nomura confuse the issue or create an even greater barrier to the negotiations by mentioning Hu11's four points?

Konoye was elated that Washington was reacting so favorably to "his and his colleagues' proposals." Later Matsuoka would cal1 these men "Anglophiles." Needless to say at this point, Konoye and his colleagues were impressed with the progress and believed a small ray of hope was still glimmering for an agreement with the United States that would insure peace for the two nations. 63

In the 19th Liaison Conference of Apri1 18, 1941, it was decided after Konoye presented a synopsis of Nomura's cable that before any decisions were made about the "American proposa1," they should wire the Foreign Minister and urge him to return immediately and wait to hear what he would have to say.

It is not known to what extent Foreign Minister Matsuoka has been informed of this matter. . . We should study it further until the Foreign Minister returns, and then decide what position to take. It was agreed, therefore, to wire the Foreign Minister, urging him to return as soon as possible. 64

It had been the intent of Konoye to send immediate instructions to Nomura, but Vice Foreign Minister Ohashi insisted until Matsuoka returned they must wait and get his agreement.

The Foreign Minister was informed of the conversations over the phone by Konoye and was thoroughly elated. Kase, who had been present when the phone call was received, reported:

On April 21, Matsuoka arrived at Dairen where he intended to stay for one or two days. As he was resting at the residence of the president of the South Manchurian Railway the telephone rang. Konoye was at the other end, asking for him. An important 
proposal from Washington had been received a few days previously, and the cabinet was anxiously awaiting the return of the foreign minister. Would he fly home immediately? As he put down the receiver Matsuoka was beaming. The conversation with Steinhardt had borne fruit! After his return to Tokyo Matsuoka elatedly told me he would soon fly to the United States to complete his peace program. 65

The Foreign Minister arrived home on April 22. He discovered that the "proposa1s" were not due to his efforts but rather to informal talks.

To his amazement he discovered, on reaching Tokyo, that the American proposal mentioned by Konoye had originated in a series of 'informal' conversations between two American Catholic priests and an ex-official of the Japanese Treasury Department whose integrity was rather dubious. The fact that such conversations had been inaugurated without the knowledge of the foreign minister added to the mystery. Matsuoka became skeptical and requested time for mature consideration. 66

Upon his return he attended a Liaison Conference where generally speaking, the cabinet showed him signs that they were willing to negotiate on the basis of the document, especially the army because it was anxious to end the war in China. 67

The summary report of the 20th Liaison Conference shows that Matsuoka was lengthy on his reporting of his trip, but was somewhat succinct in his discussion of the "Adjustment of Diplomatic Relations with the United States." The proposal sent by Nomura was not what Matsuoka had in mind when he had "beamed" with happiness. He needed time to think, he told the other members of the Liaison Conference.

- - the proposal differed considerably from what he had in mind, and that he would like to think about it at his leisure after he had taken care of some business matters during the next few days. - . The Foreign Minister left the Conference early to go home, saying that he was tired because he hadn't had much sleep since the day before yesterday. 68 
Matsuoka requested two weeks to think over the "Draft Understanding" before sending further instructions to Nomura. 69 The fact that he needed this extra time, which was from "two weeks to two months," to decide what position to take toward the United States upset the majority of the participants in the Conference. The majority felt that it would be a mistake to take too long in determining policy toward either the United States or Germany. Inspite of Matsuoka's opinion that time was needed before a decision could be made, "the majority felt that negotiations should be resumed as soon as possible since it was necessary to work on American psychology."70

In the next few days repeated efforts by army and navy ministers, as we11 as by others, were made to attempt to change Matsuoka's delaytactics. At this point there was even the suggestion of dismissal of the foreign minister, but he maintained his position and "evidently had sufficient support to defy the wishes of his colleagues."71

In the Liaison Meeting of May 3, the Cabinet was upset that no information or instructions had been sent to Nomura since his message of April 17. Most of the leaders felt it absolutely necessary to send an immediate reply to Nomura. Matsuoka was not in the mood to cooperate. Instead he pressed for action that would attempt to gain a neutrality pact with the United States. The summary notes of this Liaison Conference showed that most members were in disagreement to such an idea. "Almost a11 the members expressed their disagreement," yet Matsuoka pressed on and would not give in. "A11 we will do is suggest the idea. If the United States goes along with us, that's fine; if not, that's a11 right, too. If she agrees with us, we are that much ahead." The 
minutes of the Conference reveal that, "The majority clearly opposed the pact, and there was silence for a while." Prime Minister Konoye broke the silence with this question to Matsuoka. "Since everyone is opposed to a neutrality pact, how about withdrawing your proposal?" Matsuoka replied: "Let me think about it. One thing we might do would be to treat it lightly, by proposing it to them as if Nomura had just happened to think of it. Anyway let me think about it." The entire matter of the pact, it seems, was left up to him.

Apparently Matsuoka took it upon himself without approval, for he instructed Nomura to present the idea of a neturality pact and submit to Secretary Hull a "tentative reply" which in so many words, said that the Axis leaders were confident of victory and that if America played a part in the war it would bring about the fall of civilization. Japan would be on the side of the Axis and in no way would she injure her partner of the Tripartite Pact. 72

It is obvious to the student of this era of diplomatic history that Matsuoka was causing the great ship Japan to steer a German-bound course. Langer and Gleason claim that Matsuoka "far from pressing on with the original proposals from Washington, was doing his utmost to confuse the issue and sabotage the projected negotiations."73 Kase disagrees with Konoye's interpretation that the Foreign Minister's actions were a piece of willful sabotage. 74 In a telegram to Germany, the German Ambassador to Japan te11s of a conversation with Matsuoka in which the latter explained the opposition with which he was coming into contact. He believed that he could steer the cabinet in such a way as to destroy any chances of understanding between Japan and the United States. 75 
Regardless of Matsuoka's destructive tendencies and his proGerman steerings, it cannot be forgotten or emphasized enough that Admira1 Nomura did such a faulty job of reporting what had taken place in his meetings with Hull in mid-April that there was very little opportunity for success in the Hul1-Nomura conversations. As Butow asserts:

- - from the very beginning of the Hull-Nomura conversations, the opportunity for peace inherent therein was impaired by a fundamental misconception on the part of Japan's leaders. The generally poor communication existing among them by virtue of the indirection and vagueness traditional in Japanese thought and speech was now rivaled by an equally serious problem of communication between Japan and the United States. The officials in the American capital never realized the nature of the Japanese error, nor, for that matter, did the leaders in Tokyo. The army conference in question produced a decision in favor of going ahead on the basis of the "American plan." The Navy was consulted and found to be in general agreement. Konoye, who believed implicitly that he was dealing with an American proposal, was also of the same view. Following his return from Europe, Matsuoka proved to be a major stumbling block and, consequently, a continuing source of difficulty for his colleagues. In view of what is now known about Iwakuro's role in formulating that proposal, the Foreign Minister's assessment of the "Draft Understanding" as representing 30 per cent good will and 70 per cent evil intent provides perhaps the ultimate irony. In the end, Matsuoka's objectives were overcome. . . 76

On May 7, Hu11 was "tested" on a non-aggression pact by Nomura and the Secretary immediately "brushed it aside" as an "entirely different matter." The Government was not considering anything except "broad principles."77 A Matsuoka-authored "oral statement" was to have been given to Hull but Nomura found it to be so inflammatory that he chose only to read portions of it to Hull. Some of the "oral statement" was to inform Hull that the German and Italian leaders considered the war as good as won, that American intervention would only prolong the war and cause misery and human suffering. The President of the United 
States held the key to whether this would occur and that Japan would not do anything to jeopardize the Tripartite Pact. 78 Nomura chose only to read parts of it to Hull and told Hull that many things in the text "were wrong," but offered to give it to Hull who declined to accept it.79 Matsuoka's return to Japan could not be said to have brightened the situation between the United States and Japan but rather as it has been feared in Washington, he "cast a long shadow over the future."80 Bowing and bending to pressure from the Germans, Matsuoka stalled off any instructions concerning the "Draft Understanding" until May 12 so that the Axis powers would have time to respond to the American-Japanese negotiations. 81 At this time, Japan finally submitted her "answer" to the "American proposa1" of April 17.

What Japan was proposing to the United States was that America should take "no aggressive measures as to assist any one nation against another;" that the United States join with Japan in a "joint over lordship" of the Pacific area with Japan in control of nine-tenths of the population and wealth; 82 and that the United States was to cut off aid to Chiang Kai-shek if he refused to negotiate with Japan. The wording was changed from Iwakuro's draft of mid-Apri1, to eliminate Japan's pledge to refrain from force in the Southwest Pacific. 83

Hu11 maintained that very little was offered in this document that was acceptable to "basic principles," yet to give an absolute "no" to Japan would be throwing away one of the few opportunities the United States would have to talk over differences. America decided to move on with the talks and attempt to arrive at a consensus that both countries could agree on. 
Very few rays of hope shone from this document. What Japan was proposing was mostly to her own advantage . . it offered little basis for an agreement, unless we were willing to sacrifice some of our most basic principles, which we were not.

The basic question was, "should we talk about it even though we cannot buy the goods?"

To have rejected it outright would have meant throwing away the only real chance we had had in many months to enter with Japan into a fundamental discussion of a11 the questions outstanding between us.

The President and I figured that if there were the slightest possibility of inducing Japan to withdraw from the Axis alliance, we should pursue it, for this would be a sharp blow to Hitler and a fillip to the Allies. Even a gradual withdrawal of Japan would have its worth.

Consequently we decided to forward on the basis of the Japanese proposals and seek to argue Japan here, eliminating there, and inserting elsewhere, until we reach an accord we both could sign with mutual good wi11. 84

Between May 12 and July 23 there were some twenty-five to thirty talks in Washington alone trying to reach "an accord" until Hull suspended the talks after the Japanese attack on South Indo-China. 85

The Japanese "proposa1" of May 12, was argued back and forth during the next ten weeks. The discussions and arguments always were in Hull's apartment at night where Hull was able to utilize his speciality. His speciality, or "cup of tea," was prolonged endurance to listening for the meaning or intent of diplomatic language and hidden meanings. Hul1's speacial ability was a prerequisite to "understanding the Japanese intent." "No leaf turned over outside the room, no look traveled within the room of which he was not aware."86 Actually Nomura need never have appeared in Hu11's apartment. Hull always knew the fu11-scale word-for-word texts the Japanese Foreign Ministry was sending Nomura. The British and American governments through "Magic" were 
intercepting and decoding all Japanese cables sent to the mainland of America. Yet, "never by a single phrase or hint during the many hours of talk, did Hull give any token of knowing more than he was supposed to know. 187

During these sessions with Nomura there was hope from the Department of State that possibly these talks could open the door to peace between the United States and Japan. Every effort was made by Hull to see if Japan's course might be changed. Offers were given to the Japanese that contained "nothing extra or guaranteed; only a chance to live at peace, and by hard and patient work earn the means of living on their crowded islands." 88 The State Department was asking Japan in these "informal talks" to make these three decisions:

The first point was that Japan should stop all acts of force in the Southwest Pacific. The second was Japan should concede the fact that the aid the United States was giving Great Britain was an act of self-defense. A result of this concession on the part of Japan would be that in the event of war between Germany and the United States, she should not join forces with Germany against the United States. The third point was that Japan should begin scheduled troop withdrawals from China. 89

On the second and third points there was little success. For example, on May 20, with a meeting of not only Nomura but also Colonel Iwakuro and Ikawa, Hull observed there were two points concerning the proposal and what it had to say about China. One was in regard to the joint defense against communism and the other was in regard to the stationing of Japanese troops in certain parts of Chinese territory. It 
was necessary said Hull, to deal with these issues since, "he would have to tell Chiang the basis on which Japan would propose to negotiate." Colonel Iwakuro was surprised that this was even brought up "as it was his conception that the central objective of the proposal which we were discussing was the peace of the Pacific between Japan and the United States and that the settlement of the China affair was incidental and concerned China and Japan."90 Hull assessed the value of Iwakuro's views.

From time to time Nomura varied in his opinions on evacuation of Japanese troops from China; but Iwakuro never changed his view that the stationing of Japanese troops in northern China was an absolute condition of any settlement with China. And it was likely that Iwakuro's views on this point would prevail since he was the representative of the Japanese Army, which was determined to remain in China. 91

The second point the United States would have liked the Japanese to accept was almost single-handedly destroyed by Matsuoka's attitude toward the United States. This attitude was conveyed in press statements, talks with Ambassador Grew, and his influence upon the Cabinet in Tokyo.

It was believed by the President and Hull that Japan would side with Germany in the event of a conflict between Germany and the United States if the Foreign Minister had his way about it. Yet, there was still a chance that Matsuoka might fall from his position. Father Drought had reported that Matsuoka might be overthrown. Ikawa had gotten this information from Konoye and passed it on to Father Drought. 92 There was a group of "moderates" that gave Grew some hope. Grew had telegraphed the State Department on May 13, that the majority of the members of the cabinet were against having a war with the United 
States and that they were trying to find an interpretation within the Tripartite Pact that would free them, without losing face or honor from having to assist Germany in the case of a conflict. 93

There was never a better chance for solving the Ame rican-Japanese issue than during mid-May through July since opposition to Matsuoka was very evident on a widespread and influential basis.94 But even with a11 of this hope of "a change of staff and heart," the talks were of very little value, except that possibly they bought time for both countries. Matsuoka stood his ground and literally refused to allow the talks any chance of success.

The position that "the Americans were changing their attitude about negotiations" was becoming evident to the Tokyo decision-makers. The only problem was that Tokyo was using as her "yardstick" the "Draft Understanding" prepared in Washington by Colonel Iwakuro of the Japanese Army and not the State Department. Tokyo had presumed America's attitude in April more favorable than it actually had been. When Hull issued the Draft plan of June 21, this was the first proposal on which the United States was willing to base its position on negotiations with Japan. Japan, it seemed, became more inflexible as she felt the American position was also. Those in Japan who had never really trusted the United States and these "talks" found it very easy to create barriers of interference in negotiations by pointing out the change in attitude between the "first" proposal of mid-April, which Nomura had so incorrectly presented, and the "second" proposal of June 21.

One should remember before "casting the first stone" at Nomura for his inaccurate reporting, that he never really wanted the post, nor did 
he feel adequately prepared to play the part of ambassador. The fact is very obvious, Matsuoka chose to send a man who had only limited experience in foreign affairs, one who for one reason or another did not hear and respond to what Secretary of State Hull was saying in the meetings of mid-April and later. Matsuoka definitely chose a man who was not a professional diplomat; instead of sending the best, he sent the "second-string."

Yet one must take a hard look at the influence of Matsuoka and the reasons behind his attitudes toward the "conversations." Even though there was little hope for success, why was he so negative toward the discussions? Why did he on May 14 try to infuriate Ambassador Grew with his statements that America was taking war actions against Germany?

The role Yosuke Matsuoka took throughout these conversations was that of the "devil's-advocate." Matsuoka was showing men that he would do pretty much what he pleased. This attitude and deed were the reasons for his downfa11.

Matsuoka in the Liaison Conference of May 15, conveyed the pressure that Germany was placing upon Japan to remain removed from any agreement with the United States. Ribbentrop cabled Matsuoka to let him know how worried and upset Germany was over these discussions.

We think Japan is well aware that the American proposal is going to hinder her efforts to build the Greater East Asia Co-prosperity Sphere. With this proposal, the United States will obtain security in the Pacific, mitigate the antiwar sentiment among her people, and be able to turn in any direction she chooses. If the United States enters the war, so will Japan. Therefore, the United States wants to manipulate the situation so as to prevent war between the United States and Japan, so that she can play an active part in the Atlantic theater. The United States is also expected to aggravate the situation and provoke Germany to take reprisals against her-thus shifting the responsibility for initiating war onto the Axis countries--and then enter the war herself. Accordingly, Germany hopes that Japan will make it clear that she is 
prepared to consider the American proposal only if the United States agrees to refrain from these activities. We ask that Japan inform both Germany and Italy before sending a final answer to the United States, since this proposal greatly affects the Tripartite Pact. 95

Matsuoka, it appears, took on a hostile attitude, one in great sympathy with Germany towards the United States. He reported to the Conference of May 15, that he had attempted to convey his views to Hul1 through Nomura. Nomura had on receiving the document wired back and told Matsuoka that to give Hu11 this type of material "would make the negotiations very difficult and obstruct our reaching an understanding."96 Nomura refused to give the document to Hu11. Matsuoka wanted this message presented but realized that Nomura would not obey. He chose to make sure the message was given and spoke to Grew. He told Grew in terms "bellicose both in tone and substance" that he was afraid the United States might convoy ships to Britain; that "the manly, decent, and resonable thing for the United States to do would be to declare war openly on Germany since our attitude toward Germany is provocative" in the face of our supplying war materials to Great Britain; and that Hitler had been as patient about this as possible and had not called America to war:

The Minister thereupon makes perfectly clear his interpretation of the Tripartite Pact to the effect that if the United States should convoy its ships to England and if Germany should sink such ships, and if war with Germany should result, he, Mr. Matsuoka, would regard the United States as an aggressor in the sense of Article 3 of the pact, and it is his belief that war would thereupon ensue between Japan and the United States.97

Matsuoka had estimated the success of the Hul1-Nomura conversations ending in an agreement to be only three out of ten.98 
In a meeting between Hull and Nomura on May 28, Hull told Nomura of a major problem confronting the success of the "talks," namely this was Matsuoka's public declarations of Japanese support of Germany if America entered the war.

Mr. Matsuoka since his return from Europe, according to reports widely published in the press, has been making declarations on every occasion in regard to Japan's obligations under the Tripartite Alliance in the matter of supporting Germany in the event of American entry into the war. He said that, if we went into an agreement with Japan, critics would assert, unless the Japanese Government could clarify its attitude toward its obligations under the Tripartite Alliance in the event that the United States should be drawn into the European war through action in the line of self-defense, that there was no assurance as to Japan's position. . . The Ambassador replied that he had known for many years, that Matsuoka was given to talking a great deal for domestic consumption in Japan, but that the Ambassador was convinced that Matsuoka desired only friendly relations with the United States. 99

In the New York Journal American, Matsuoka was quoted as saying in response to an American correspondent's question,

Japan's attitude and policy regarding the obligations of the Tripartite Pact are, as I have repeatedly affirmed, crystal clear, and there is no question that we will faithfully observe them.

Japan will also pursue the course and in East Asia which she has been following unwaveringly in the past, namely, establishment of a new order throughout the region of Greater East Asia.

Nothing will alter or influence that course or policy. 100

The members of the Japanese "proposal" team would swear that Tokyo's readiness to yield on any point was given, yet at another place in the world, newspapers would be recording words that were quite to the contrary. Konoye records in his Memoirs, translated by Langer and Gleason, that Matsuoka refused to retreat, even as much as an inch, in discussions concerning negotiations with the Americans. 101 
In a telegram to Berlin dated June 21, the German Ambassador to Japan, Ott tells Ribbentrop of his discussion with Matsuoka. Matsuoka had informed ott that regardless of the discussions with America, Japan was moving into Indo-China. He had been informed by Nomura that Hul1 wanted to attach a speech, in which the Secretary of State had attacked Germany's practices, as a part of "their proposa1." Matsuoka declared to Ott that this "Draft" was "a nonsensical proposal" which only proved that the United States wanted the negotiations to fail--1aying the blame on Japan. He had also told ott that he would handle the proposal business in such a way that the blame for the failure of the discussions would fall completely on the United States. 102

The sulkiness and uncooperativeness toward the American-Japanese negotiations by Matsuoka was noticed. Matsuoka on May 8, had told the Emperor that he would resign his position if Japan's handing of the American situation would result in a policy that would cross her promises and obligations already made to Germany and Italy. A secret meeting came out of this where Konoye, Tojo and the Navy Minister Oikawa discussed ways of dealing with Matsuoka's attitude toward the United States. It was decided that they would have to watch the Foreign Minister very carefully and keep each other informed of his methods and manners. 103

On June 22, Germany attacked Russia. Matsuoka immediately wanted the cabinet to decide to go to war with Germany and break off relations with the Soviet Union. So adamant was Matsuoka about this that Konoye did not understand the intentions of the foreign minister, nor did many of the members of the cabinet. 104 
A move was made by Hul1 on June 21 that created quite a reaction. He had sent by way of Nomura a "rewrite" of the proposals the Japanese had given the United States on May 12. Attached was a1so an oral statement. The document was quite lengthy, accompanied by annexes and drafts to be exchanged. In so many words, Hull told Nomura the aggressions of Hitler could not be ignored, as was suggested in the May 12 proposal; that the only kind of understanding Japan wanted was one in which the United States would endorse Japanese attacks against the United States if the United States became involved in the "European War" as a result of her policy of self-defense. 105

The ora1 statement was interpreted as meaning that the American government could not trust Japan's foreign minister.106 It was diplomatic in tone yet, Matsuoka was stomping mad. He called the Hull message a national humiliation.

In the 39th, 40th, and 41st Liaison Conferences of the Japanese Government, Matsuoka urged Japan to break off negotiations with the United States (July 10-24). He demanded that the "oral statement" be returned to Washington immediately. More secret meetings followed without the presence of Matsuoka. In the days shortly after his demands, the conference ignored Matsuoka. The army and navy jointly asked that negotiations with the United States be continued and not broken off. A counter-proposal was agreed to by all members, including a reluctant Matsuoka, and was drawn up. The members of the conference agreed to send the "counter-proposal" as soon as possible, immediately, to the United States. Matsuoka used his delay tactics of feigning sickness so as not to be able to check over the "final draft." But during his sick stay, he was able to inform the German ambassador of the contents of the 
counter-proposal and the latest communications from the United States. The cabinet was "burning" with anger at Matsuoka's defiance. He finally agreed to read the "counter-proposa1" by July 14, at which time he made several revisions. It was now ready to be sent to Washington, but still Matsuoka balked. He did not want to send the "counter-proposal" until Japan had returned the "oral statement" of Hull's. His intent seemingly meant that unless the United States withdrew the "oral statement," negotiations would have to cease. The Conference determined to disregard Matsuoka's wishes and send both at the same time. Matsuoka brazenly took matters into his own hands and cabled Nomura and told him the "Oral Statement" was rejected. He told Nomura nothing about the "counterproposa1."107

On July 16, Konoye met privately with his cabinet members who had participated in the 1iaison conferences to deal with the "home, sick in bed," Matsuoka. An immediate resignation was agreed upon, with the formation of a new cabinet following the next day, with the same lineup, minus one Yosuke Matsuoka.

The leaders of Japan had believed that as long as Matsuoka was foreign minister it was highly unlikely a diplomatic settlement with the United States could be obtained. In addition to his being a stumbling block in those negotiation processes, his determination to go against the wishes of the Supreme Command caused his fall from power. It is notable that Matsuoka seemed to believe that the foreign minister had the right of dictating the foreign policy regardless of the desires of other ministers and other powers. The Supreme Command may have wanted the same outcome as Matsuoka, yet it was not prepared to relinquish 
its power and bow to his every wish. Matsuoka had attempted to tell the army how to deal with Singapore, with Indo-China and Thailand, and with the German-Russian war. He had become a pest, trying to push the Supreme Command around as if they were his to order. He had locked horns with the "real power" of Japan. It was no contest. Matsuoka was defeated.

The effect of Matsuoka upon the relations of Japan to the United States was immense. He had steered a course that was not different from what the Supreme Command had wanted, a course that was "Germanbound." His presence as Foreign Minister to Japan, made it almost virtually impossible for the United States to even begin to gain a "foothold" on the mountain of "peaceful settlement." No individual man, it can be'said, had such an effect on the failure of the United States and Japan to communicate as did Matsuoka. 


\section{CHAPTER III}

\section{FOOTNOTES}

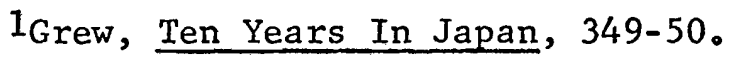

${ }^{2}$ Langer and Gleason, The Undeclared War, 311.

3 Robert J.C. Butow, "The Hu11-Nomura Conversations: A Fundamental Misconception," American Historical Review, LXV, No. 4 (July 1960), 82236.

4 Ibid., 822.

$5 \mathrm{Grew}$, Ten Years In Japan, 350.

$6_{\text {Langer and Gleason, The Undeclared War, } 311 .}$

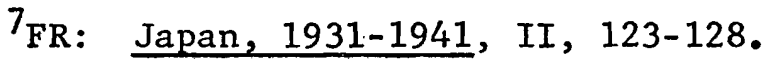

8 Ibid.

${ }^{9}$ Ibid., $128-29$.

10 Langer and Gleason, The Undeclared War, 311.

$11_{\text {Feis, }}$ The Road to Pear1 Harbor, 172.

12 Ibid.

13Shigemitsu, Japan and Her Destiny, 220-21.

14Langer and Gleason, The Undeclared War, 314.

15Butow, American Historical Review, LXV, No. 4, 823.

16 Langer and Gleason, The Undeclared War, 314.

17 Ibid.

18 Ibid.

${ }^{19}$ Ibid. , 314-15.

20 Ibid. 


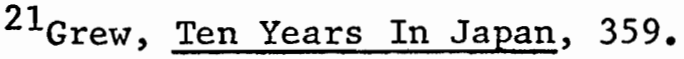

22FR: Japan, 1931-1941, II, 330.

23FR: Diplomatic Papers, 1940-1941, III, 260-267.

24FR: Japan, 1931-1941, II, 133-35.

25 $\mathrm{Hu} 11$, Memoirs, II, 985.

26 Butow, American Historical Review, LXV, No. 4, 823.

27FR: Diplomatic Papers, 1941, IV, 14-16.

${ }^{28}$ Butow, American Historical Review, LXV, No. 4, 823.

${ }^{29}$ Langer and Gleason, The Undeclared War, 321.

30FR: Diplomatic Papers, 1941, IV, 14.

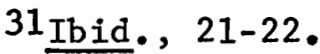

32Hu11, Memoirs, II, 984-86.

33 Butow, American Historical Review, LXV, No. 4, 824.

34 Ibid.

$35_{\text {Butow, Tojo, } 310 .}$

36 Ibid.

37Toland, The Rising Sun, 67.

38 Butow, American Historica1 Review, LXV, No. 4, 825.

${ }^{39}$ Toland, The Rising Sun, 67.

40 Butow, American Historical Review, LXV, No. 4., 825.

41 Hu11, Memoirs, II, 984-85.

${ }^{42}$ Toland, The Rising Sun, 67.

43FR: Japan, 1931-1941, II, 398-402.

44 Hu11, Memoirs, II, 991.

45Feis, The Road to Pearl Harbor, 177.

46 Hu11, Memoirs, II, 993-94. 
47 Ibid.

${ }^{48}$ Ibid.

${ }^{49}$ Ibid.

50FR: Japan, 1931-1941, II, 407.

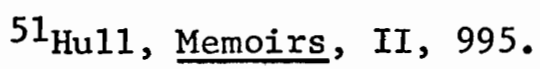

52FR: Japan, 1931-1941, II, 409.

53 Ibid.

$54_{\mathrm{Hu}}$, Memoirs, II, 996.

55FR: Japan, 1931-1941, II, 410.

$56_{\mathrm{Hu}}$, Memoirs, II, 996.

57 Butow, American Historical Review, LXV, No. 4, 829.

58 Ibid., 829-30.

59FR: Japan, 1931-1941, II, 410.

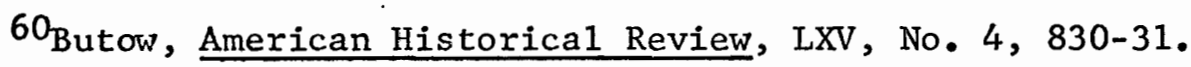

61 Ike, Japan's Decision for War, 17.

62 Langer and Gleason, The Undeclared War, 470.

${ }^{63}$ Ibid., 471-72; Ike, Japan's Decision for War, 17-18.

${ }^{64}$ Ike, ibid., 18.

${ }^{65}$ Kase, Journey to the Missouri, 45.

$66^{\text {Ibid. }}$

67 Ike, Japan's Decision for War, 19.

68 Ibid., 19-24.

69 Ibid.

70 Ibid., 20-21.

$71_{\text {Langer and Gleason, The Undeclared War }}$, 473-74.

72 Ibid., 474. 
73 Ibid.

$74 \mathrm{Kase}$, Journey to the Missouri, 45.

75Langer and Gleason, The Undeclared War, 474.

76 Butow, American Historical Review, LXV, No. 4, 833.

77FR: Japan, 1931-1941, II, 412.

78 $\mathrm{Hu} 11$, Memoirs, II, 998.

79FR: Japan, 1931-1941, II, 412.

80 Langer and Gleason, The Undeclared War, 474.

${ }^{81}$ Ike, Japan's Decision for War, 31.

82 Butow, American Historical Review, LXV, No. 4, 833.

${ }^{83}$ Ike, Japan's Decision for War, 31.

${ }^{84} \mathrm{Hu} 11$, Memoirs, II, 1001 .

85Feis, The Road to Pearl Harbor, 199.

${ }^{86}$ Ibid., 172 .

87 Ibid.

${ }^{88}$ Ibid., 203.

89FR: Japan, 1931-1941, II, 446-54; Ike, Japan's Decision for War, 43.

90FR: Japan, 1931-1941, II, 434-35.

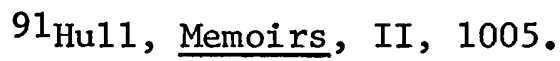

92 Langer and Gleason, The Undeclared War, 476-77.

93 Ibid.

94 Ibid.

${ }^{95}$ Ike, Japan's Decision for War, 34-36.

96 Ibid., 34.

97Grew, Ten Years In Japan, 388; FR: Japan, 1931-1941, II, 146-48. 
${ }^{98}$ Ike, Japan's Decision for War, 36-43.

99FR: Japan, 1931-1941, II, 440-41.

100 Langer and Gleason, The Undeclared War, 481.

101 Ibid. , 479.

102 Ibid.

103Butow, Tojo, 230 .

104 Ike, Japan's Decision for War, 36-43.

105FR: Japan, 1931-1941, II, 486-92.

106 Ibid., 485.

107Ike, Japan's Decision for War, 93-107. 
CHAPTER IV

\section{KONOYE'S CHANCE}

With Matsuoka now removed from office, what efforts, what documents, what signs were given that would reveal the intent of the two countries to stay out of war? How were the negotiations looked upon? The new Japanese cabinet was an indication of the strength the military had in the affairs of state. Matsuoka, a civilian, was replaced by ViceAdmiral Teijiro Toyoda. Seven of the fourteen ministers in the new line-up were military men, including four generals and three admirals. ${ }^{1}$ This cabinet was definitely a military cabinet, even though one might believe that with the shedding of Matsuoka a "change of heart" or a reversal in the "swing of the pendulum" should have occured. This was not the case, thanks to "Magic," the United States learned through the "new" foreign minister that the agreement Japan made with Germany and Italy was still "the keystone of Japanese national policy," and in no way would there be "departure" from the Pact. ${ }^{2}$

The misconception that Nomura created in sending the "Draft Understanding" of April to Tokyo with the thought that it was an American proposal, had created by June 21 the belief that America was "bearing down" and changing her attitude and policy to a much stiffer and more inflexible position. What effect would this interpretation have, even if incorrect, on the possibility of a successful settlement? Many members of the cabinet were turning to the thought of war as the 
proper tool for settlement of issues between the two countries.

In early July the United States received an indication of what was to come which was not exactly positive in nature. Japan moved into the southern portion of French Indo-China. This did not appear to the United States as meaning Japan was curtailing her expansionism and deciding to honor the sovereignty of other nations. American inte11igence received more news of the Japanese intentions. A message was intercepted and decoded by "Magic" and was given to the State Department of the United States by July 8. It stated in part, "Although every means available shall be resorted to in order to prevent the United States from joining the war, if need be, Japan sha11 act in accordance with the Three-Power Pact and shall decide when and how force will be employed." 3 The United States attempted to help the French by inviting Japan to take part in a multilateral guarantee that would declare IndoChina a neutral nation. 4 This failed.

In the past sanctions had already cut off various supplies and materials from the United States and other countries to Japan. It appeared at this point to the President and his advisors, that this "economic sanction" was hardly effective and that it was time to "restructure" the economic barriers against Japan. The physical-cue given Japan that would hopefully end her policy of expansionism in Aisa, was an executive order freezing all Japanese funds and assets in the United States, dated Ju1y 26, 1941.

The reaction in America was one of general agreement. It had been believed by many in America that the Japanese were being allowed use of America's goods and supplies only to turn around and use them in a 
manner that went against basic principles. ${ }^{5}$ The Japanese must be stopped was the feeling.

The order of July 26, created just the opposite reaction. It brought about somewhat of a "threat" from the "new" foreign minister, Toyoda. He warned Ambassador Grew that if "any provocative attitude or any concrete step" was made by the Americans to interfere with what measures Japan and French Indo-China "were compelled to take for the sake of their self-defense," on the shaky ground that they had acted in contradition to "general doctrinarian principles," the government of Japan could not promise to hold back the great upsurge of national indignation to this and to the already-maddening fact that the United States was aiding the enemy, Chiang Kai-shek. Counter measures would be taken, Toyoda wrote to Grew.

- - In such a case, there is a danger that Japan would be forced to take some countermeasures, to the destruction of al1 the hopes of myself as well as the present Cabinet to prevent by all possible efforts the coming about of such a situation.' This would be much to be dreaded, indeed, for the maintenance of friendly relations between Japan and the United States and the peace of the Pacific. 6

That same evening after he had received the Foreign Minister,

Ambassador Grew forecasted war, unless there were some "radical surprises."

The vicious circle of reprisals and counter-reprisals is on. - . Unless radical surprises occur in the world, it is difficult to see how the momentum of this downgrade movement in our relations can be arrested, nor how far it will go. The obvious conclusion is eventual war. 7

On July 28, the Japanese froze American assets and funds. The American embargo in turn was enlarged by an order on August 1 , which prohibited the export to Japan of certain materials (wood pulp, metals 
and metal products, machinery and vehicles, rubber and rubber products, chemicals and related products) and petroleum products that were of high enough grade to be used as aviation gasoline. 8 The economic squeezeplay was on and Japan unintentionally was being forced to find another source for with the rest of the sanctions came the one worst feared, oil. Japan was to receive no more oil from the United States. More indications of what the United States was attempting to do to the Japanese were given. The Panama Canal was shut down for repairs. The United States nationalized the Philippine Army making it a part of the United States Army forces in the Far East. The President had recalled MacArthur from inactive duty to go to the Philippines to lead this force. ${ }^{9}$

The give-and-take reprisals were causing Konoye a considerable amount of uneasiness. On August 2, he told Kido about his concern that the navy was even thinking more in terms of force as the solution for dealing with the United States. This was a new element in the game. The navy had wanted to avoid taking on Great Britain and the United States in a war where the responsibility of defeat or victory would fall in their laps. At least this was true until June, 1941. But with the denial of fuel which was all important to the navy, and the negotiations not making any progress, they would rather have sought a decision at sea than die in the harbor. ${ }^{10}$ Konoye was finding the argument in favor of using force gaining more and more momentum. The more "hawkish" element in Japan was becoming more and more concerned about Japan's diminishing fuel supplies. 
The whole problem facing Japan had been reduced to oil. Many of the members of the Rooseve1t Cabinet, especially Hu11, had been aware that the embargo on oil would bring about a real strain on the relations between the two countries. The reason for the strain on Japan was that the navy had only enough oil to last for eighteen months, while the army had bare1y enough to last one year. This was hardly enough oil to win a war of any length with the United States, let alone a two-front war against the United States and Russia.

Japan had several choices: create synthetic petroleum, take the Netherlands East Indies which had vast amounts of oil resources or avoid a "gradual impoverishment of military supplies and resources" through an expansion of Japan's domestic facilities and an increase in production. 11 She opted for the first and last choices over taking the Netherlands East Indies for fear of immediate military reprisals on the part of the United States. The one very important option not considered by Japan was that of abandoning her military policy which would eliminate the need for oil.

As it became quite clear that Ambassador Nomura was not doing the job successfully nor making any headway, the army and navy staffs grew less interested in continuing the negotiations. A "now or never" psychology had been gaining headway. Rather than die by the wayside with negotiations, force, it was believed, should be used before it was too 1ate. 12

The Japanese who were unsure of American intentions in her military preparations in the Pacific, gave the United States many indications by August that Japan was aiming towards military solutions for Japanese- 
American differences and not negotiations. Konoye was stumbling feebly against the momentum, attempting not to move with the current of opinion in favor of war. This would be a commitment he was not willing to take Japan towards. That Konoye would not commit himself to taking his country to war was one of the basic reasons he would lose his post. The sanctions placed on Japan during late July certainly played a part in moving Konoye to the end.

The messages decoded by "Magic" and what Nomura would say were not always the same. America's compromising ability certainly was hampered by the truth which came through "Magic." On July 31 , the code breakers caught this message from Foreign Minister Toyoda to Ambassador Hiroshi Oshima in Germany.

Commercial and economic relations between Japan and other countries, led by England and the United States, are gradually becoming so horribly strained that we cannot endure it much longer. Consequent1y, the Japanese Empire, to save its very life must take measures to secure the raw materials of the South Seas. It must take immediate steps to break asunder this ever strengthening chain of encirclement which is being woven under the guidance of and with the participation of England and the United States, acting like a cunning dragon seemingly asleep. 13

Yet on August 6, Japan offered the United States a "new" proposal which was in part a response to President Roosevelt's proposal to neturalize Thailand and Indo-China. The Japanese promised not to station troops in Southwest Pacific areas aside from Indo-China and would withdraw from Indo-China after the settlement of war in China. In exchange the United States was to suspend all military preparations in the southwestern Pacific area, restore normal trade relations with Japan, cooperate with Japan in getting the raw materials she needed from the southwestern Pacific area, urge Chiang Kai-shek to make peace 
with Japan and recognize Japan's special role in Indo-China, even after she removed her forces. It can be said that with the decoding of July 31 , any belief the Rooseve1t administration had in Konoye's power to settle Japanese policies had ended. 14

Two avenues of thought and hope for settling matters with the United States emerged. There was a segment including Konoye who supported the "Konoye-Roosevelt talks" as a road to solutions. Another segment, heavily military and including the Supreme Command's spokesman, Hideki Tojo, was determined to begin laying plans for a solution by military means.

The development of war plans was the avenue selected while the avenue of talking with Roosevelt was left up to Konoye. The oil-guage reading wás causing not only a decision for war, but it was also creating a need for plans. The army in the past had always made the plans and the navy and the cabinet would okay them in that order. But now, War Minister Tojo urged the navy to come up with a plan that would be so well laid that it would create a spontaneous belief in navy and army circles in its ability to bring about success. 15 Planning took in points such as the resources the army and navy would need and also the time hostilities would begin. It was decided by the Imperial Military Headquarters that to be sure of enough oil, rubber, rice, bauxite, and iron ore it was necessary to get swift control of Java, Sumatra, Borneo and Malaya. The United States would have to be expe1led from Wake, Guam and the Philippines, and the British from Singapore in order to protect transport lines from the above locations. The weather in this part of the world played an important part in determining the 
time for war. The military felt that the best time for action was the months of October and November. December was possible but difficult. January or later would be impossible because of the monsoons. 16

The army made plans to capture Malaya, Java, Borneo, the Bismark Archipelago, the Indies and the Philippines. They were to be fully ready by the end of October. The navy finished its war games which included a mock-up of the surprise attack on the American fleet in Pearl Harbor. At the end of these games the army and navy staffs conferred and found their plans satisfactory. 17 According to Butow, as early as August, war preparations were to be made "on the basis of a determination not to run away from a war" with Great Britain, the Netherlands and the United States. 18 Also in August, the military had recommended that diplomatic efforts go hand in hand with war preparations.

Konoye had noted in his diary the true emphasis was on force. He wrote that after the freezing of Japan's assets, the Army General Staff began to advocate war on the grounds that further negotiation was useless. 19 The war preparations, no doubt, blinded many of the military officers and those of the "center" in looking for other solutions to the Japanese-American differences.

The outcome of the embargoes, the concern of the United States for Great Britain and her threatened colonial possessions in Southeast Asia, the interpretation by the Japanese that the attitude of the United States toward Japan was becoming more rigid, the fact that the Americans and the British were able to decode the Japanese messages and know exactly what they were sending throughout the world, and the failure of 
the negotiations between the United States and Japan to bring about immediate solutions to the problems were reasons for there being little hope by either nation at this point for peaceful settlement. Both countries had their goals and were not capable of changing them to compromise for the other's views or needs. There were no concessions offered by the two countries.

War versus peace became the debate question in the Liaison Conferences. Those conferences of early September were in almost constant session working on an "Outline for the Execution of the National Policy."20 Konoye was beside himself because as General Suzuki, Head of the Planning Board told it after the war from the Far East Military Tribunal stand, "the Supreme Command was in favor of making a decision then and there for.war; calling off negotiations with the United States; but Konoye opposed, suggesting that no time be set when war was to be commended, on 1y war preparations."21 Konoye received a short postponement of about six weeks. He did yield to the argument that if Japan did not fight for what she wanted soon, she would not have a fair opportunity for victory. This was because it was the general belief in military circles that American defenses were steadily getting stronger and Japan's oil supply steadily lower. 22

Prince Konoye went to the Emperor to present the following adopted outline which was to be used in the next day's Emperor's Conference. The outline was in three parts. The first part dealt with securing Japan's nationa1 existence. To accomplish that war preparations should "proceed -. . so that they be completed approximately toward the end of October." The second part stated that "At the same time, we will 
endeavor by every possible diplomatic means to have our demands agreed to by America and England." The third part is dependent upon the failure of the second:

If by the early part of October there is no reasonable hope of having our demands agreed to in the diplomatic negotiations with America to mentioned above, we will immediately make up our minds to get ready for war against America. ${ }^{23}$

The emperor upon seeing the outline was upset and inquisitive about the fact that this document appeared to put military preparations before diplomatic negotiations. He was so upset that he called the Chiefs of Staff of the army and navy to learn of their intentions. 24

Konoye records the meeting between the Chiefs of Staff, the Emperor and himself. Konoye points out that the Emperor's questions show his keen $\operatorname{logic}$ on September 5, 1941. He asked the Army Chief of Staff to estimate the length of the war if one should come about with the United States. Sugiyama thought it could be disposed of in approximately three months. The Emperor reminded Sugiyama that he had been the Minister of War when the "China Incident" broke out and at that time the same question was asked of him and the Emperor reminded him, he had estimated one month but fighting had now moved into its fourth year. Sugiyama "in trepidation," explained that the "extensive hinterland of China prevented the consummation of operations according to the schedule." At this remark the voice of the Emperor became louder and more intense as he pointed out that "if the Chinese hinterland was extensive, the Pacific was boundless." He wanted to know how Sugiyama could be positive that this calculation of three months was correct. Sugiyama could not answer, he had been silenced by the logic of the Emperor. The 
Navy Chief of Staff tried to aid Sugiyama by this analogy:

- - to his mind Japan was like a patient suffering from a serious illness.. . the patient's case was so critical that the question of whether or not to operate had to be determined without delay. Should he be let alone without an operation, there was danger of a gradual decline. An operation, while it might be extremely dangerous, would still offer some hope of saving his life. The stage now was reached . . where a quick decision had to be made one way or the other. 25

The Navy Minister felt that Sugiyama was in favor of putting hope in the negotiations to the end, but that if they failed a decisive action militarily would have to be taken. He told the Emperor that to this extent he was in favor of negotiations. The Emperor wanting a firm commitment from the two "chiefs" asked them if it was not true then that they were in favor of diplomacy as being first on Japan's priority list. They both answered with a "yes". 26

From September 5 on, every debate which was held on questions of war or peace always ended on the same note. Strike while Japan had the power. This decision expanding hostilities into the Pacific was made sometime between August 16 and September 5, by the army and navy. From this point on, for all practical purposes, the "arrow of war had left the string and was flying toward its target," the only possibility of stopping this flight would be if the United States accepted the terms of Japan or the Supreme Command lost its monopoly of decision-making powers. 27

Still the pseudo-priority of diplomacy-first was carried on. Had any offers by Japan or the United States been made that would make this priority effective? The "Iwakuro-Draft" was still the main crux of Japanese diplomacy which had originally been a "keen disappointment" to 
Hu11 and Roosevelt. Even though Matsuoka was removed, his belief that "taking a firm stand" was necessary to deal with America properly was a continuing carry-over of policy. This "firm stand" had in the past worked in the dealings of Japan with her Asian neighbors, but not so with the United States which seemed to be gaining strength in her conviction that there were basic principles that all nations should agree to and abide by. China could hardly be left alone by the United States which would bolt the open door closed to them, and more important, Japan could not be allowed to combine with Germany to conquer Russia and Britain. If these were hard and fast positions taken by the United States, which they were, what was left for compromise? A JapaneseAmerican compromise or settlement restricted by these many facets on both sides of the Pacific had little chance for success.

American diplomatic efforts strained at not appearing "too rigid," lest an immediate conflict be created. The United States diplomatic efforts were not going to give in on the Hull "principles" but instead they were trying to postpone a conflict in hope for some settlement other than war. Hul1 had written that upon the arrival of Nomura he had estimated the chances to be very slim that success in negotiations were possible.

Japan's past and present record, her unconcealed ambitions, the opportunity for aggrandizement lying before her while embroiled Europe demanded a large part of our attention, and the basic divergence between our outlooks on international relations, were all against the possibility of such an accord. The President and $I$ agreed that the existing treaties relating to the Far East were sufficient, provided the signatories, meaning especially Japan, lived up to them . - but if new agreements would contribute to peace in the Pacific, we believed we should not throw the chance away. .28 
Hu11 cites the reasons for postponement and patience on the part of the United States as being basically defensively unprepared and the fear of starting a war in the Pacific which would make the British and Dutch colonial possessions even more vulnerable to the spreading expansionism of the Japanese. Hull wrote that everything possible would be done "to bring about a peaceful, fair, and stabilizing settlement of the whole Pacific question. We knew we would have to be patient, because the Japanese government could not, even if it wished, abruptly put into reverse Japan's march of aggression. ... But . . while carrying no chip on our shoulders . . we could not sacrifice basic principles without which peace would be illusory."29

By the summer of 1941, the stalemate between the two countries had been pretty firmly set. Sterner measures were being taken by the Americans to brace themselves defensively against the threat of what was happening in Asia. While in Japan, an attitude of preparation for immediate action was being evidenced.

Inspite of assurances made by Konoye and the military to the Emperor that they would place diplomacy first before war preparations were put in action, these were off-set by the deadline placed on determining whether Japan would choose a route of war or peace. In considering the possibility of war with the United States, the members of the Japanese liaison conference naturally had to give some thought to the chances of winning or losing. It was openly stated that great risks were involved and that no sure victory was in view. Yet still the "now or never" psychology prevailed. 30 
In September there had been little evidence that the negotiations would bring about the needed changes the "Iwakuro Draft" had suggested. On September 18, the chiefs of the army and navy staffs called for a final attempt at diplomatic negotiations with the United States. If this final attempt failed then Japan was to move on to the second phase of the outline of September 5, which was "war preparation" for troop movement and fleet disposition necessary for launching hostilities. 31 The phase one and two program was accepted by Konoye on September 20, but much to his amazement and shock, the Supreme Command was demanding as part of the two-step outline, a deadline for either war or peace. It was determined that this decision for either would be made, at the latest, by October 15,32

Konoye retreated from his duties to think on the Supreme Command's demand that a decision for war or peace be made by October 15 . He determined to resign as Premier and told this to the "Lord Keeper of the Privy Sea1," Kido. Kido would not accept this decision and instead urged Konoye to take the initiative in calling for a reconsideration of the entire question of war or peace. Konoye accepted this advice and contacted what he thought to be the weak link in the cabinet, Navy Minister Koshiro Oikawa. The Navy Minister was questioned by Konoye concerning the attitudes of the navy about the deadline for war or peace. The navy minister wanted the negotiations continued between the United States and Japan. His opinion was the same as Foreign Minister Toyoda. This group of three men, Oikawa, Toyoda, and Konoye were those who opposed such a deadline calling an end to the negotiations. Konoye had been told by the chief of the navy general staff that he agreed with the demand of the army for an immediate policy of action. 
Konoye had believed that if the navy balked at the deadline set for war or peace the army could be held in check. 33 But with the stand the chief of the navy general staff had taken, there was little hope that the army demand could be changed. To make matters worse for Konoye and his hope in the negotiations, he received word from Washington.

Konoye had all along kept up hope and faith in the possibilities of the proposed "Konoye-Roosevelt Talks." He had received permission from the Supreme Command to meet with Roosevelt. He was to stick to the already defined position Japan had given in her previous negotiations, which were the Emperor's "true intentions." If he had no success in these meetings he was told that he must be willing to return to Tokyo and lead the Japanese into war. 34 There was actually 1ittle faith in the talks by the Supreme Command. 35 The "true intentions" of course were those that had been prevalent in the discussions of Hull and Nomura. To accept them America would have had to remove herself from the China, situation with Japan, have nothing more to say about the Alliance with Germany, and restore normal economic relations with Japan. The fact that on October 2 , Konoye received word that the United States did not consent to the request of the "Roosevelt-Konoye" talks gives evidence that America realized the talks were not going to be anything different or new. 36 An immediate post-war comment by Konoye reveals his feelings on the rejection of such talks. The government "was unable to control the Japanese militarists in the field, or often didn't know what the militarists were doing. It was that way when I was trying to see Rooseve1t. - . The government was considered a liar, because no matter what we promised regarding China, final 
decision on the removal of our troops from China depended upon the military. That was one reason why the meeting was never held."37 Konoye's "ace in the hole" was dropped. He received word from Hull that a conference between the two leaders could serve no useful purpose without establishing a common ground of agreement, a theme mentioned several times before by Hull. The members of the group that wanted direct action for war could now say to Konoye who had faith and hope in diplomacy, "We told you so."

The Army felt that there was no point in continuing the negotiations and that Japan should decide for war. However, some Navy Leaders--particularly the Navy Minister-were reluctant to see the negotiations broken off. Their reluctance stemmed from their lack of confidence in Japan's ability to win a prolonged war with the United States.38

Some authors assign a great deal of importance to this note of October 2 from the United States. It would seem from Konoye's own testimony that little would have been accomplished at these proposed meetings. The Konoye Cabinet's fate was sealed. It was time for the Cabinet to "make up its mind" whether or not definitely to prepare for war with the United States. 39

Hu11 in his note of October 2, had suggested that Japan, as an "earnest of good faith," should withdraw its troops from China and IndoChina, and then possibly a compromise could be drawn up. Konoye, without delay, attempted to do this by arguing for a partial evacuation of China. 40

Even though Konoye resisted the death of the talks-idea, his lastminute stand for concessions was not productive. For three days he retreated with the navy and foreign minister, to talk about "methods of 
avoiding a crisis." 41 But Konoye was held in place by the decision of September. The Cabinet was deadlocked.

The navy wanted the whole responsibility of going to war placed on Konoye's shoulders. The army did not agree with this. On October 12, Tojo said that each member of the cabinet bore the responsibility of "tendering his advice" and "assisting the throne." This meeting of five major ministers failed to alter the balance between continuing negotiations or going to war. With the failure of this conference to solve the issue of whether to go to war or not, Konoye was faced with either leading the nation of Japan into war or stepping aside for another person who would take Japan to war if it were necessary. 42

The Cabinet attempted once more on 0ctober 14 , to settle the matter, but failed. Konoye made plans to resign and collected resignations from his cabinet members. On October 16, he and his cabinet resigned making room for a new man with a new approach, one with an ability to draw the navy and army together and, above a11, one who could fulfill the wishes of the Emperor.

After some discussion with the Emperor and the Cabinet, the man selected for the job was General Hideki Tojo. He was given a clean slate, a new start. He was the one who was to break the deadlock and not necessarily lead Japan into war.

The Konoye Cabinet, it can be said, resigned because of a deadlock over whether to go to war or not. One can view this deadlock as a gradual growing process that had its roots in the summer of 1941 and was now in full bloom in mid-October. A hardening on both the United States and Japanese sides took place during this time to the point where 
neither could bend an inch. The fall of the third Konoye Cabinet can be attributed to a development of "war fever" brought about by the economic sanctions of the United States and her statements of policy according to "Hull's basic principles." These were interpreted somewhat incorrect1y as meaning "the United States is getting tougher rather than more lenient" in her policy toward Japan. As a result of these American actions, a "now or never" psychology developed which Konoye and some of his cabinet would not accept.

For Konoye and some of his cabinet members, the decision for going to war was beyond their grasp. They were not prepared to plunge Japan into a war which they were not sure Japan could win. Instead, Konoye stepped aside to let someone else take that particular burden of responsibility. 
CHAPTER IV

FOOTNOTES

$1_{\text {Butow, }}$ Tojo, 233 .

2Feis, The Road to Pear1 Harbor, 229-30.

3Butow, Tojo, 222 .

${ }^{4}$ Ibid.

5Langer and Gleason, The Undeclared War, 651-53.

6 Ibid., 653-54.

$7_{\text {Grew, }}$ Ten Years In Japan, 408.

8Langer and Gleason, The Undeclared War, 655.

9Dona1d Drummond, The Passing of American Neutrality, 1937-1941 (Ann Arbor, Michigan, 1955), 274.

10Butow, Tojo, 235.

$11_{\text {Ibid. }}$

12 Ibid.

13Feis, The Road to Pearl Harbor, 249-50.

14FR: Japan, 1931-1941, II, 549.

15 George Waller (ed.), Pearl Harbor: Roosevelt and the Coming of the War (rev. ed., Massachusetts: D.C. Heath and Company, 1965), 39.

16 Ibid.

17 Ibid.

18Butow, Tojo, 247.

${ }^{19}$ Ibid., 246; Langer and Gleas on, The Undeclared War, 713.

20Ike, Japan's Decision for War, 129. 
$21_{\mathrm{Fe}}$ is, The Road to Pear1 Harbor, 264.

22 Ike, Japan's Decision for War, 129-33.

23 Ibid.

24Langer and Gleason, The Undeclared War, 713.

25Feis, The Road to Pear1 Harbor, 266-67.

26 Ibid.

$27_{\text {Butow, Tojo, } 255 .}$

28Hu11, Memoirs, II, 985-86.

${ }^{29}$ Ibid.

30 Ike, Japan's Decision for War, 134.

$31_{\text {Butow, Tojo, } 262 .}$

32Ike, Japan's Decision for War, 176.

33 Ibid., 177.

34Butow, Tojo, 244 。

$35 \mathrm{Grew}$, Ten Years In Japan, 426-27.

36 Butow, Tojo, 245.

37 Ibid.

38Ike, Japan's Decision for War, 181.

39Mil1is, This is Pear1! , 169-70; Jones, Japan's New Order in East Asia, 290.

40 Drummond, The Passing of American Neutrality, 1937-41, 311.

41 Ibid., 312.

42 Butow, Tojo, 255. 


\section{CHAPTER V}

THE QUESTION AND ANSWER

Hideki Tojo the newly appointed Prime Minister described his cabinet as that of one with a "clean slate." But the "chalk was placed in the hands of those who made the earlier mark."1 Whether a "war" cabinet or not, the average person in Japan agreed that it was. In America, the talk of a clean slate was regarded as sheer "trickery," an attempt to hide the war preparations. ${ }^{2}$ In reality, Tojo had not been given this job to lead Japan down the road to war, but rather to break the deadlock or stalemate created by the Konoye Cabinet. In order to do this, Tojo and his cabinet began meeting almost daily for two weeks following his appointment to establish a "national policy."3

After more than a year of negotiations that were stalemated between the United States and Japan, one wonders how clean the slate really was that Tojo received. Were there any attempts to negotiate with the United States at this point? And if there were, what in actuality was new or different abouther negotiations from the two previous Cabinets' diplomatic gestures?

On November 20, 1941, the United States received a diplomatic message that sha11 be called "the question" and on November 26, Japan received from the United States a message that sha11 be called "the answer." 
The background of the diplomatic representation of November 20 , began in the 65th Liaison Conference of October 30, when the Cabinet was under tremendous pressure for an oil supply and time. Prime Minister Tojo told the Liaison members that a decision would have to be reached on November 1 , even if they had to meet all night. They would concern themselves with three proposals. The first was to avoid war and undergo great hardships. The second was to decide on war and immediately settle matters by war. The third and final proposal was to decide on war but carry on war preparations and diplomacy side by side. 4

In the 66th Liaison Conference on November 1, the line-up for the various proposals fell with either the second or the third. The War Ministry supported heavily the third proposal. General Tojo, Navy Minister Shimada, Finance Minister Kaya, and Director of the Planning Board Suzuki were also in favor of the third proposal. The Army Staff supported the second proposal. There was only one member, Foreign Minister Togo, who was uncertain about which was the correct proposal. It was not uncommon for the members of the Cabinet to know prior to these meetings how each person felt, or what would be said. Tojo had attempted to smooth over the feelings of the Army Staff concerning Proposal Two with 1ittle success, prior to the Conference. 5

The 66th Liaison Conference was a long one, lasting some seventeen hours, extending to 1:30 a.m. November 2. The group went along with a demand from the navy for a large allocation of steel which appeared to be the price it demanded for a war decision.

Proposal One was quickly discarded because Japan presently had a foundation for war; the members of the conference were not sure Japan 
could win a war in three years; and the philosophy seemed prevalent that it would be easier for Japan to engage in a war at this time rather than at a later date.

The Supreme Command, it seems, was the author of Proposal Two. A possible reason for the creation of Proposal Two was a belief that Japan could not gain what she wanted through negotiations and that any further efforts to talk by the Japanese would only aide the United States. 6 In reading the translations of the original records of the 66 th Conference, one is impressed with the discussion of Proposal Two and the fact that the cabinet would not even consider peace by making concessions to the United States of any kind. Most of the cabinet members and the military leaders had virtua11y accepted the fact that Japan had to take a route which would give her control over much of southeast Asia. Japan, at this point was unwilling to readjust her objectives so that a peaceful settlement might be obtained.

It seems that the on1y members of the cabinet troubled over the thought of immediate war were Togo and Kaya. They eventually succumbed to the argument of Nagano and Suzuki that it was presently the right time for war since the operational conditions for conflict would not last much longer with the coming of the monsoon season and a1so the availability of materials for a war were lessening. During the discussion of Proposal Two, the army chief of staff had presented a proposed attachment to Proposal Two which Togo and Kaya could not accept. The attached proposal read,

Japan gives up hope of success in negotiations, and is determined to begin war against the United States, Britain, and the Netherlands at the beginning of December. Negotiations with 
the United States will be continued until then in order to gain an advantage in war. An attempt will be made immediately to strengthen ties with Germany and Italy. 7

Kaya and Togo responded to this inserted portion by letting the Cabinet members know that they desired somehow to make a last try at diplomatic negotiations. "It's outrageous to ask us to resort to diplomatic trickery. We can't do it."8 The Army Vice-Chief of Staff, Tsukado, responded with the argument that they should deal with the central issues first, which were "to decide immediately to open hostilities," and that "war will begin on the first of December," then study the possibilities of diplomacy. Tsukado was the product of many months of waiting for diplomacy with little or almost nothing to show for it. The Navy Vice-Chief of Staff, Ito, said that the navy was prepared to allow Japan to negotiate until November 20 and Tsukado said that this was too long for the army. The army would not allow negotiations to continue beyond November 13. Foreign Minister Togo responded to the deadlines given by the army and navy by giving his objective for diplomacy which was successful negotiations.

You say there must be a deadline for diplomacy. As Foreign Minister, I cannot engage in diplomacy unless there is a prospect that it will be successful. I cannot accept deadlines or conditions if they make it unlikely that diplomacy will succeed. You must obviously give up the idea of going to war. ${ }^{9}$

From this reply of Togo's, it was quite obvious that clarification on the deadline and conditions for diplomacy needed to be made. With this in mind, Tojo suggested that the discussion also include Proposal Three. Tsukado repeated what was attached to Proposal Two and demanded that "diplomacy must not obstruct military operations," and that November 13 had to be the deadline. 
This emphasis on war over diplomacy worried Tojo and Togo enough that they demanded from the Supreme Command their word that they would not go to war if diplomacy were successful. Tsukado told them that this would be entirely impossible if success were achieved after November 13. The reason it could not be accepted after this date was that it would throw the Supreme Command into confusion in its plans and strategies. This reply ignited several comments that were of a volatile nature. In fact words were flying so heatedly that Tojo declared a twenty-minute break to cool the men down. It was also an opportunity for Tojo to attempt to regroup his cabinet. 10

The outcome of the break and discussion was that the leaders of the Sup reme Command finally gave in to accept midnight, November 30 , as the deadline for halting diplomatic discussions with the United States.

Was this to be considered a "change of heart" on the part of the Supreme Command?. Proposal Three was accepted. A decision for war was made; the time for the beginning of the war was set; and the negotiations were allowed to continue until one second before December 1 , with the stipulation that if successful, war would be called off. 11

Now that a deadline for diplomacy had been set, what would be negotiated? Would it be a new approach, or the same as the "IwakuroDraft?" How would Japan go about obtaining a peaceful victory?

In the same seventeen hour long conference these questions were dealt with. The reply to the questions came in the form of two proposals. Proposal "A" and Proposal "B" were the titles given by the cabinet. 
Proposal "A" was a somewhat reduced version of the past proposals presented in the negotiations with the United States through Nomura.12 Proposa1 "B" was an "extraordinary diplomatic document." In short, it allowed Japan to concentrate on a new military offensive which would give them complete control over the people of China for their withdrawing of troops from Southern Indo-China. 13

Proposa1 "B" was selected by the members after a "thorough" discussion. It is quite evident that at this point the Supreme Command and a number of the cabinet members believed war to be inevitable which made Proposal " $B$ " even harder to swallow. Over the selection of "A" or " $B$ " the members of this lengthy meeting had their second "battle." The Supreme Command was again arguing with the Foreign Minister. The main point of contention for the Supreme Command, seemed to be withdrawal of Japanese Troops from Southern Indo-China. This was incredulous to them and thus, they wanted to use Proposal "A". Togo became adamant, and from this arose the fear that he might resign. If he did this it might cause the "war" cabinet to fal1.14 A ten-minute recess was called to regroup and cool down. Sugiyama, Tojo, Tsukada, and Muto conferred and decided on three points. The first was that the discussion could not be allowed to last any longer. It would be final that the deadline for war was to be set within the first ten days of December. The Supreme Command demanded fixing this time span for war. The second point was that the Cabinet could not be permitted to fall. If it happened, it would precipitate a selection of an anti-war cabinet. The third and last point decided upon during the ten-minute break was an "unenthusiastic" agreement to use Proposa1 "B". The army had given carefu1 
consideration to whether it would give in and agree to a softening of conditions, the withdrawal of troops from Southern Indo-China as bait for Proposal "B". 15

Proposal "B" was to be used in spite of the Supreme Command's complaints, doubts, and belief in an inevitable war. It was decided that the withdrawal of troops from Indo-China was to be used only "if necessary" in the talks with Hull. None of the members of the conference were overly enthusiastic about the possibility of success of Proposal "B". This final attempt at diplomacy allowed little chance for successful negotiations and was defeated even before it was cabled to America. Although there were some who voiced some optimism in the Proposal, they were few in number. Tojo when returning from the conference he had with the Emperor to explain what had transpired in the 66th Liaison Conference had said, "Proposal B is not an excuse for war. I am praying to the Gods that somehow we will be able to get an agreement with the United States with this proposa1."16

What was the reaction to the diplomatic negotiations that had taken place so far? Public opinion in the United States had worsened steadily with the pro-German statements made by Matsuoka, and the troop movements of Japan into Indo-China. Japan was still seen as the "aggressor." She was still seen as "unjust" in her activities in China. The American was not completely aware of the intricacy of the discussions but knew that they were not entirely successful. Chiang Kai-shek did not like the soft way the United States was handling the Japanese. 17 Grew was convinced that war was inevitable unless the United States relaxed her economic restraints. 18 Grew had called for these same economic 
restraints earlier in 1941 to curb the Japanese actions of expansionism in southeast Asia. The only accomplishment the embargoes had made, in Grew's estimation at this point, was in leading the United States and Japan on a collision course for war. This estimation caused him to reverse his previous call for economic restraints against Japan. Little had been accomplished in the negotiations with Japan. The State Department was seeking backing from the military and naval forces concerning their demands on Japan. $19 \mathrm{~B}-17^{\prime} \mathrm{s}$ and $\mathrm{B}-24^{\prime} \mathrm{s}$ were in place on some of the islands in the southwest Pacific. The United States was aware that they had no way of intercepting "enemy" planes or warning the airfields of an attack. The United States was desperately hurrying to establish a string of air-fields across the southwest Pacific for more of these bombers. 20

The military was trying to work with the State Department of stall any break with the Japanese for as long as it was necessary. General Marsha11, commented that he and Admiral Stark were doing everything within their power to delay a crisis occuring with Japan until the last moment ". - because of our state of unpreparedness and because of our involvements in other parts of the world." 21

The American Navy was weak to say the least, for a two-ocean navy. It was presently committed to an undeclared naval war in the Atlantic with Germany and was hardly capable of a naval war with Japan in the Pacific. Time was needed by the United States to prepare for a conflict. On November 5, the same day Japan had originally decided to go to war if both proposals were rejected, Stark and Marshall made these recommendations to the President. 
That material aid to China be accelerated consonant with the needs of Russia, Great Britain, and our own forces. That aid to the American Volunteer Group be continued and accelerated to the maximum practicable extent. That no ultimatum be delivered to Japan. 22

The United States was unprepared defensively to fight with Japan and at the same time unable to obtain a peaceful compromise or settlement with her. The United States had taken an uncompromising stand diplomatically through the leadership of Hull and Roosevelt with Japan. 23 Militarily the United States had taken on an undeclared naval war with Germany. At the same time the United States wanted to maintain peace in the Far East with Japan even though Britain and the United States were not happy with the position Japan held in China and Indo-China. The thought of forcefully taking on Japan had to be set aside as a secondary priority to that of the European war and the likelihood the United States would soon be drawn into it officially. Physical action could not be taken by the United States against Japan. Instead, words were to be used as a temporary method of holding off any conflict the United States might have with Japan. But the opportunity for words being used was lessened by factual information. "Magic" had given the Americans a more realistic, knowledgeable insight of Japan's intentions diplomatically. With the decoding, the United States learned that the negotiations coming after November 5, were to be "their last chance." Secretary of State Hul1 put his office to work, attempting to come up with a solution to the "magic" interceptions. An attempt was made by the department to prove to Japan that she could gain more through peaceful means in the areas of trading and financial arrangements than she could through the use of force. Yet the United States had certain principles, stated by Hull, which hardly left room for the type of concession Japan would require 
to stop her war machinery from being put into action. 24

It can safely be deduced that at this juncture of history, prior to the negotiations offered and replied to on November 20 , and 26 , respectively, the American government felt a desperation about the turn of events and a necessity to seek more time to strengthen her own hand.

In Washington the Proposals were delivered by Nomura. It had been aggreed on by the Japanese Cabinet to attempt, first of all, Proposal "A", realizing that the chances of America accepting it slim, since it only restated the negotiation demands of Japan that had been in American hands since Apri1, 1941. If this was rejected, then Proposal "B" would be offered. Nomura, because of his own insecurities at not being able to "get any where" with the Americans, and possibly his own feelings of inadequacy and incompetency, requested that he be allowed to resign his post or if not that, at least be allowed a "professional diplomat" to help him in the dealings with the Americans. Saburo Kurusu was sent. His arrival was marked by Proposal "A" being rejected by the Americans. 25

It seems that Admiral Nomura took off on a self-initiated idea which suggested the two nations return to the situation of diplomacy prior to July. This would mean that Japan would have to evacuate her troops from Southern Indo-China and that in return the United States would have to remove her economical barriers and pressures to the position they had been prior to July. Was this too large of a price to pay for peace? Nomura seemed to think it not. When the "non-professional" Nomura cabled his action to Tokyo, Tojo upon receiving it immediately returned this cable. 
Postpone meeting with Hull until we send instructions. . . There will be trouble later if we proceed in a piecemeal fashion to settle problems. This method is not satisfactory. Indicate clearly to the United States that when you sent your personal suggestion to Tokyo, Tokyo instructed you that Proposal $\mathrm{B}$ must be agreed upon in its entirety. Hereafter proceed with negotiations on the basis of Proposal B. 26

Nomura had his hands slapped and was further reminded that these proposals had been his final orders. Nomura's main problem was that he was used to being his own man to a certain degree and did not understand the implications of being a diplomat nor in some cases did he want to understand.

Nomura and Kurusu placed Proposal "B" before Hu11 on November 20. The text, of course, had already been intercepted and read by Hull. He knew that this was the "last bargain." One senses the frustration and anxiety the Secretary of State suffered in knowing this was the last offer and that it was not acceptable.

The commitments we should make were virtually, a surrender. - . - The President and I could only conclude that agreeing to these proposals would mean condonement by the United States of Japan's past aggressions, assent to future courses of conquest by Japan, abandonment of the most essential principles of our foreign policy, betrayal of China and Russia, and acceptance of the role of silent partner siding and abetting Japan in her effort to create a Japanese hegemony over the western Pacific and eastern Asia. 27

On the 22nd of November the 71st Liaison Conference members reinforced a decision made earlier by saying rejection by the United States of Proposal "B" would mean war. 28

What would have happened if the United States had agreed to the tenents of this proposal? China having been deserted by the United States would have had little confidence in the United States. Other colonial nations would have had little hope that the United States would 
have been able to help if needed. If the United States had accepted this Japanese proposal, the proposal probably would not have had a very Iong 1ife. It would have probably fallen apart with war breaking out in the Pacific. Neither side would have slowed down preparations for war in the Pacific causing arguments over "arms," and if that were not enough, then the subject of oil and the need for more of it by Japan would have ended the truce. This proposal would have only opened the door for more Japanese demands and would have created more problems between the two nations. 29

On November 22, the Japanese Ambassador and Kurusu called at the Secretary's apartment where they always met for these "talks." During this session, even though Hull had been working all day to make up an offer to counter Proposal "B", he checked to see if the Japanese government had given them any more concessions to deal with. They had not been given any. 30

During that same day Hull with the help of the members of the State Department, had come up with a counter proposal for a modus vivendi--a temporary arrangement of affairs pending final settlements. Along with the temporary arrangement a list was made up of principles the Japanese and Americans would have to both subscribe to in order to live peacefu11y. He inquired of the emissaries of China, the Netherlands, Great Britain and Australia two different times to see how they felt about the modus vivendi and 1ist of principles. Great Britain and China reacted violently to the proposal modus vivendi. China believed that an adoption of such a modus vivendi would cause a collapse of the Chinese resistance to the Japanese. Churchill cabled Hull suggesting 
that this project be abandoned. 31 The modus vivendi idea was discarded after careful study. It was decided though, to try through a response to the negotiations of November 20 to arrive at a truce. The State Department did this with an agreement ". . that the American offer would only be for the record."32 This offer would do nothing, it was felt, to stop the coming invasion to the south which "magic" had reported. The only thing that mattered to the pessimistic staff in Washington was that in the line of tradition, the United States was not to be the one to fire the first shot. 33

The "answer" was given to the Japanese "question" at 5:00 p.m. (Washington D.C. time) November 26. The "answer" basically told the Japanese that a11 she had wanted was to be denied. The "answer" did not stop there, but offered instead of acceptance of Proposal "B", certain alternatives. Even though the Japanese had determined this was "the last chance," the United States attempted to keep the negotiations alive on these points. It was suggested that a mutual cooperation on the grounds prior to July, 1941 be established. It suggested that Japan sponsor a meeting similar to the Nine-Power Treaty of the 1920's where a non-aggression pact among all the countries of the Far East could be presented and hopefully accepted. The mere fact that the proposal had not been accepted was enough to ke11 negotiations. The suggestion that the Japanese remove al1 her troops from China and Indo-China, would create quite a response in Tokyo. 34

The Japanese Cabinet had been informed by the "dumbfounded" Kurusu and Nomura that instead of a "yes" to Proposa1 "B", two hard proposals were given which they believed Japan would find impossible to accept. 
We were both dumbifounded and said that we could not even cooperate to the extent of reporting this to Tokyo. We argued back furiously, but Hull remained solid as a rock. Why did the United States have to propose such hard terms as these? We11, England, the Netherlands, and China doubtless put her up to it. Then, too, we have been urging them to quit helping Chiang, and 1ately a number of important Japanese have been urging in speeches that we strike at England and the United States. Moreover, there have been rumors that we are demanding of Thai that she give us complete control over her national defense. A11 this is reflected in these two hard proposals, or we think so. - . Unfortunately, there are no hopes of acceptance of our demands within the time limits you set. 35

Along with the statements from Japan's diplomats the Cabinet recieved a copy of the American reply which was regarded as an ultimatum.36 The Cabinet felt that if this were accepted it would lower her to a thirdrate power. A11 the Japanese needed now for war was the Emperor's approva1. The Cabinet assumed that the end of the road had been reached as far as negotiations were concerned. All attention now was to be focused on the war. 37

But the question must be asked, why did Japan look upon this "answer" as an ultimatum? The Japanese were the ones who had created an "ultimatum." The fact that they had 1imited negotiations to a mere formality without hope of success was evidence that their proposal was an ultimatum. The knowledge now that the Imperial Fleet heading for Pear1 Harbor with a scheduled attack for December 7 , had left at six o'clock on November 26 is evidence that shows they placed little value on Proposa1 "B". 38 The value they had assigned to Proposal "B" was acceptance or there would be war. This definitely falls into the category of ultimatums. The fact, also, that Japan refused to reply to the American "answer" of November 26 showed that they were holding to their 
original decision which meant war. Japan upon receiving the American reply called it an ultimatum, leaving Japan no choice except war. Japan had been left with four choices, which removes the November 26 "answer" from the category of ultimatums. The Japanese could choose to agree to the American "answer" and reverse her policy. She could choose to abstain from any further advances to the north or south and continue her war with China. She could choose to begin a retreat from China and see what the United States, China and Great Britain would return for her withdrawa1. Or, finally, she could choose to "draw her guns" and make a bid for all of Asia. 39 Hardly an ultimatum, Japan chose the last alternative.

Grew, upon reading the "answer" to the Japanese "ultimatum" found it met al1 the Japanese were fighting for.

It is a broad-gage, objective, and statesmanlike document, offering to Japan practically everything she had ostensibly been fighting for if she will simply stop her aggressive policy. - - Japanese public opinion can always be molded, in a comparatively short time, and the clever move of the Government now would be to persuade the public that the Government in the Washington conversations, had won a great diplomatic victory by achieving, without further force of arms, the securities or "freedoms" for which she had been fighting. 40

The fact that the Japanese did not study this document sent by Nomura and Kurusu was more evidence that the course was established and the "discussions" had ended.

War would break out on December 7, 1941 with Japan striking at the Naval Fleet of the United States in Pear1 Harbor. The stalemated negotiations had been unable to deter war. Neither nation had been willing to offer concessions which might have purchased peace. 


\section{CHAPTER V}

FOOTNOTES

$\mathbf{1}_{\text {Feis, }}$ The Road to Pearl Harbor, 287.

${ }^{2}$ Shigemitsu, Japan and Her Destiny, 259.

3Butow, Tojo, 315.

4Ike, Japan's Decision For War, 198.

5 Ibid.

6Butow, Tojo, 319 .

7Ike, Japan's Decision For War, 202.

${ }^{8}$ Ibid.

${ }^{9}$ Ibid., 203.

10 Butow, Tojo, 321.

11 Ike, Japan's Decision For War, 204.

12 Ibid.

13Butow, Tojo, 322 .

14 Ike, Japan's Decision For War, 206.

15 Ibid., 207.

$16_{\text {Ibid. , } 208 .}$

17Paul Schroeder, The Axis Alliance and Japanese-American Relations, 1941 (New York, 1958), 212.

${ }^{18} \mathrm{Grew}$, Ten Years In Japan, 468.

${ }^{19}$ Feis, The Road to Pear1 Harbor, 299.

$20_{\text {Ibid., }} 300$. 
21 Ibid.

22Millis, This is Pear1!, 198-99.

${ }^{23}$ Schroeder, The Axis Alliance and Japanese-American Relations, 1941, 181.

24Feis, The Road to Pear1 Harbor, 304.

${ }^{25}$ Butow, Tojo, 334.

26Ike, Japan's Decision For War, 250-51.

27 Hul1, Memoirs, II, 1069-70.

${ }^{28}$ Ike, Japan's Decision For War, 254.

29Feis, The Road to Pear1 Harbor, 311.

30FR: Japan, 1931-1941, II, 757-59.

${ }^{31}$ Ibid.

32Feis; The Road to Pear1 Harbor, 317.

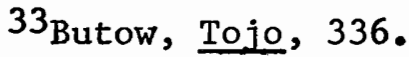

34FR: Japan, 1931-1941, II, 764-71.

35Millis, This is Pearl! , 244.

${ }^{36}$ Ike, Japan's Decision For War, 257.

37 Ibid.

38 Butow, Tojo, 340 .

39Feis, The Road to Pear1 Harbor, 321.

$40_{\mathrm{Grew}}$ Ten Years In Japan, 481-82. 


\section{BIBLIOGRAPHY}

PRTMARY SOURCES

PUBLIC DOCUMENTS

Jones, S. Shepard and Myers, Denys (ed.). Documents on American Foreign Relations, July 1940-June 1941. Vol. III. Boston: World Peace Foundation, 1941.

United States Congress, Joint Committee on the Investigation of the Pearl Harbor Attack. Pearl Harbor Attack, Hearings Before the Joint Committee on the Investigation of the Pearl Harbor Attack, Congress of the United States, Seventy-Ninth Congress. . . 39 parts. Washington, D.C.: U.S. Government Printing Office, 1946.

United States Department of State. Papers Relating to the Foreign Relations of the United States: Japan, 1931-1941. 2 vols. Washington, D.C.: U.S. Government Printing Office, 1943.

United States Department of State. Peace and War, United States Foreign Policy, 1931-1941. (Publication 1983) Washington, D.C.: U.S. Govermment Printing office, 1943.

PRIVATE

Grew, Joeseph C. Report From Tokyo: A Message to the American People. New York: Simon and Schuster, 1942.

Grew, Joeseph C. Ten Years In Japan. New York: Simon and Schuster, 1944.

Hu11, Corde11. The Memoirs of Corde11 Hu11. 2 vols. New York: The Macmillan Company, 1948.

Ickes, Harold L. The Secret Diary of Harold L. Ickes: The Lowering Clouds, 1939-1941. Vo1. III. New York: Simon and Schuster, 1954.

Kase, Toshikazu. Journey to the Missouri. Translated with an introduction by David Rowe. New Haven: Yale University Press, 1950. 
Rosenman, Samue1 (ed.). The Public Papers and Addresses of F.D.R.: 1941, The Call to Battle Stations. New York, 1950.

Shigemitsu, Mamoru. Japan and Her Destiny: My Struggle For Peace. New York: E.P. Dutton and Company Inc., 1958.

Shigenori, Togo. The Cause of Japan. New York: Simon and Schuster, 1956.

SECONDARY SOURCES

BOOKS

Appleman, John. Military Tribunals and International Crimes. Westport, Connecticut: Greenwood Press, 1954.

Beard, Bharles A. President Roosevelt and the Coming of the War: A Study in Appearances and Realities. New Haven: Yale University Press, 1948.

Bergamini, David. Japan's Imperial Conspiracy: How Emperor Hirohito Led Japan Into War Against the West. New York: William Morrow and Company, 1971.

Buchanan, Russe11 A. The United States and World War II. 2 vols. New York: Harper and Row Publishers, 1964.

Butow, Robert J.C. Tojo and the Coming of the War. Stanford: Stanford University Press, 1961.

Churchill, Winston. The Second World War: The Grand Alliance.

Vo1. III. Boston: Houghton Mifflin, 1950.

Crowley, James B. Japan's Quest for Autonomy: National Security and Foreign Policy, 1930-1938. New Jersey: Princeton University Press, 1966.

Divine, Robert A. Causes and Consequences of World War II. Chicago: Quadrangle Books, 1969.

Drummond, Dona1d F. The Passing of American Neutrality, 1937-41. Ann Arbor, Michigan: The University of Michigan Press, 1955.

Farago, Ladislas. The Broken Sea 1: The Story of Operation Magic and the Pearl Harbor Disaster. New York: Random House, 1967.

Fehrenback, T.R. F.D.R.'s Undeclared War, 1939-1941. New York: David McKay Company Inc., 1967. 
Feis, Herbert. The Road to Pear1 Harbor. Princeton: Princeton University Press, 1950 .

Ha11, John Whitney. Japan from Prehistory to Modern Times. New York: Delacorte Press, 1970.

Heirichs, Waldo H. Jr. American Ambassador: Joeseph C. Grew and the Development of the United States' Diplomatic Tradition. Boston: Little, Brown and Company, 1966.

Ike, Nobutaka. Japan's Decision for War. Stanford: Stanford University Press, 1967.

Jones, F.C. Japan's New Order in East Asia: Its Rise and Fa11, 193745. New York: Oxford University Press, 1954.

Kennedy, Malcolm D. A History of Japan. London: Weidenfield and Nicholson, 1963 .

Kirby, S. Woodburn. The War Against Japan. Vo1. I. Loss of Singapore. London: Her Majesty's Stationery Office, 1957.

Langer, William L. and Gleason, S. Everett. The Undeclared War, 194041. New York: Harper and Brothers Pub1ishers, 1953.

Latourette, Kenneth S. A Short History of the Far East. New York: Macmillan Company, 1964.

Lu, David J. From the Marco Polo Bridge to Pear1 Harbor: A Study of Japan's Entry into World War II. Washington D.C.: Public Affairs Press, 1961.

Millis, Walter. This is Pear1! The United States and Japan, 1941. New York: William Morrow and Company, 1947.

Morgenstern, George. Pear1 Harbor: The Story of the Secret War. New York: Devin-Adair Company, 1947.

Morison, Samuel Eliot. History of United States Nava1 Operations in World War II. Vo1. III. The Rising Sun in the Pacific, 1931April 1942. Boston: Little, Brown, and Company, 1965.

Potter, John Deane. Yamamoto: The Man Who Menaced America. New York: Viking Press, 1965.

Rauch, Basi1. The History of the New Dea1, 1933-38. New York: Capricorn Books, 1963.

- Rooseve1t: From Munich to Pear1 Harbor. New York: Creative Age Press, 1950. 
Schroeder, Paul W. The Axis Alliance and Japanese-American Relations, 1941. New York: Cornel1 University Press, 1958.

Storry, Richard. A History of Modern Japan. Baltimore: Penguin Books, 1960.

- The Double Patriots: A Study of Japanese Nationalism. Boston: Houghton Mifflin Company, 1957.

Tansi11, Charles. Back Door to War. Chicago: Henry Regnery and Company, 1952 .

Wa1ler, George M. (ed.). Pear1 Harbor: Rooseve1t and the Coming of the War. Revised edition. Massachusetts: D.C. Heath and Company, 1965.

Wohlsetter, Roberta. Pear1 Harbor: Warning and Decision. Stanford: Stanford University Press, 1962.

Yanaga, Chitoshi. Japan Since Perry. Hamden, Connecticut: Archon Books, 1966.

Yoshida, Shigeru. Japan's Decisive Century, 1867-1967. New York: Frederick A. Praeger, 1967.

ARTICLES

Butow, Robert J.C. "The Hul1-Nomura Conversations: A Fundamenta1 Misconception," American Historical Review, Vo1. 65, No. 4 (Ju1y 1960), 822-36.

Morton, Louis. "The Japanese Decision For War," United States Nava1 Proceedings, Vo1. 80, No. 12 (December 1954), 1325-35.

NEWSPAPERS

New York Times

The Oregonian

The Oregon Journal 